\title{
Monogenetic Basaltic Volcanoes: Genetic Classification, Growth, Geomorphology and Degradation
}

\author{
Gábor Kereszturi and Károly Németh \\ Additional information is available at the end of the chapter \\ http://dx.doi.org/10.5772/51387
}

\section{Introduction}

Plate motion and associated tectonics explain the location of magmatic systems along plate boundaries [1], however, they cannot give satisfactory explanations of the origin of intraplate volcanism. Intraplate magmatism such as that which created the Hawaiian Islands (Figure 1, hereafter for the location of geographical places the reader is referred to Figure 1) far from plate boundaries is conventionally explained as a result of a large, deep-sourced, mantle-plume [2-4]. Less volumetric magmatic-systems also occur far from plate margins in typical intraplate settings with no evidence of a mantle-plume [5-7]. Intraplate volcanic systems are characterized by small-volume volcanoes with dispersed magmatic plumbing systems that erupt predominantly basaltic magmas [8-10] derived usually from the mantle with just sufficient residence time in the crust to allow minor fractional crystallization or wallrock assimilation to occur [e.g. 11]. However, there are some examples for monogenetic eruptions that have been fed by crustal contaminated or stalled magma from possible shallower depths [12-19]. The volumetric dimensions of such magmatic systems are often comparable with other, potentially smaller, focused magmatic systems feeding polygenetic volcanoes [20-21]. These volcanic fields occur in every known tectonic setting [1, 10, 22-28] and also on other planetary bodies such as Mars [29-33]. Due to the abundance of monogenetic volcanic fields in every tectonic environment, this form of volcanism represents a localized, unpredictable volcanic hazard to the increasing human populations of cities located close to these volcanic fields such as Auckland in New Zealand [34-35] or Mexico City in Mexico [36-37].

Importantly, research on monogenetic volcanoes and volcanic fields is focused on their "source to surface" nature, i.e. once the melt is extracted from the source it tends to ascend to the surface $[11,16-17,38]$. The rapid melt generation and short eruptive history of volca- 
noes fed by these magmas mean they can be used as 'probes' of various processes, particularly to detect short- and long-term changes occurring during emplacement of a single vent and/or a volcanic field. They also provide evidence of the evolution of magmatic systems that fed numerous individual small-volume volcanoes over time spans of millions of years [39-44]. This research has led to an understanding of the processes of melt extraction [17, 45-46], interactions in the lithospheric mantle [47-49], ascent within the lower to middle crust [16, 50] and in the shallow crust region [10, 51-54]. Other studies have elucidated plumbing and feeder systems of monogenetic volcanoes [8-9, 55-57], eruption mechanisms [58-61] and associated volcanic hazards [34, 62-67] as well as surface processes [68-71] and long-term landscape evolution [72-74].

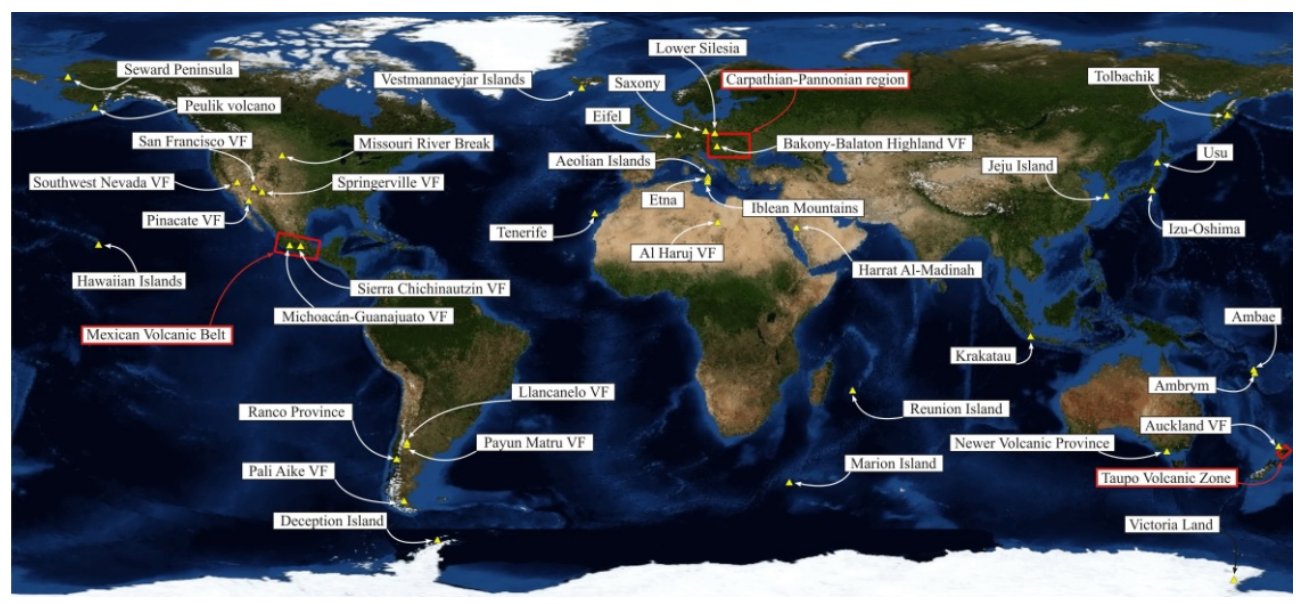

Figure 1. Overview map of the location of the volcanic field and zones mentioned in the text. The detailed location of specific volcanic edifices mentioned in the text can be downloaded as a Google Earth extension (.KMZ file format) from http://www.intechopen.com/.

Eruption of magma on the surface can be interpreted as the result of the dominance of magma pressure over lithostatic pressure [50,75-76]. On the other hand, freezing of magma en route to the surface are commonly due to insufficient magma buoyancy, where the lithostatic pressure is larger than the magma pressure, or insufficient channelling/focusing of the magma [50, 76-78]. Once these small-volume magmas (0.001 to $0.1 \mathrm{~km}^{3}$ ) intrude into the shallow-crust, they are vulnerable to external influences such as interactions with groundwater at shallow depth [79-82]. In many cases, the eruption style is not just determined by internal magma properties, but also by the external environmental conditions to which it has been exposed. Consequently, the eruption style becomes an actual balance between magmatic and environmental factors at a given time slice of the eruption. However, a combination of eruption styles is responsible for the formation of monogenetic volcanoes with wide range of morphologies, e.g. from conical-shaped to crater-shaped volcanoes. The morphology that results from the eruption is often 
connected to the dominant eruptive mechanisms, and therefore, it is an important criterion in volcano classifications. Diverse sources of information regarding eruption mechanism, edifice growth and hazards of monogenetic volcanism can be extracted during various stages of the degradation when the internal architecture of a volcano is exposed. Additionally, the rate and style of degradation may also help to understand the erosion and sedimentary processes acting on the flanks of a monogenetic volcano. The duration of the construction is of the orders of days to decades [83-84]. In contrast, complete degradation is several orders of magnitude slower process, from ka to Ma [68, 71,73]. Every stage of degradation of a monogenetic volcano could uncover important information about external and internal processes operating at the time of the formation of the volcanic edifice. This information is usually extracted through stratigraphic, sedimentary, geomorphic and quantitative geometric data from erosion landforms. In this chapter, an overview is presented about the dominant eruption mechanism associated with subaerial monogenetic volcanism with the aim of understanding the syn- and post-eruptive geomorphic and morphometric development of monogenetic volcanoes from regional to local scales.

\section{Monogenetic magmatic systems}

Melt production from the source region in the mantle is triggered by global tectonic processes such as converging plate margins, e.g. Taupo Volcanic Zone in New Zealand [85-88] and in the Carpathian-Pannonian region in Central Europe [89-93] or diverging plate margins, for example sea-floor spreading along mid-oceanic ridges [94-95]. Melting also occurs in sensu stricto "convection plumes" or "hot spots" $[2,4,96]$, which could alternatively result from small-scale, mantle wedge-driven convection cells [97]. This is often a passive effect of topographic differences between thick, cratonic and thin, oceanic lithosphere, as suspected by numerical modelling studies [97-101].

Typical ascent of the magma feeding eruptions through a monogenetic volcano starts in the source region by magma extraction from melt-rich bands. These melt-rich bands are commonly situated in a low angle (about $15-25^{\circ}$ ) to the plane of principal shear direction introduced by deformation of partially molten aggregates [95, 102-103]. The degree of efficiency of melt extraction is dependent on the interconnectivity, surface tension and capillary effect of the solid grain-like media in the mantle, which are commonly characterized by the dihedral angle between solid grains [104-105]. When deformation-induced strain takes place in a partially molten media, it increases the porosity between grains and triggers small-scale focusing and migration of the melt [104]. With the continuation of local shear in the mantle, the total volume of melt increases and enhances the magma pressure and buoyancy until it reaches the critical volume for ascent depending on favourable tectonic stress setting, depth of melt extraction and overlying rock (sediment) properties [16, 42]. The initiation of magma (crystals + melt) ascent starts as porous flow in deformable media and later transforms into channel flow (or a dyke) if the physical properties such as porosity/permeability of the host rock are high enough in elastic or brittle rocks in the crust [50, 75, 106-107]. The critical vol- 
ume of melt essential for dyke injections is in the range of a few tens of $\mathrm{m}^{3}$ [76], a volume which is several orders of magnitude less than magma batches feeding eruptions on the surface, usually $\geq 0.0001 \mathrm{~km}^{3}[39,108]$. An increase in melt propagation distance is possible if small, pocket-fed initial dykes interact with each other [50,76], which is strongly dependent on the direction of maximum $\left(\sigma_{1}\right)$ and least principal stresses $\left(\sigma_{3}\right)$, both in local and regional scales [109] and the vertical and horizontal separation of dykes [50, 76, 110]. These dykes move in the crust as self-propagating fractures controlled by the density contrast between the melt and the host rock from the over-pressured source zone [50]. The dykes could remain connected with the source region or propagate as a pocket of melt in the crust [111-112]. The geometry of such dykes is usually perpendicular to the least principal stress directions $[108,111]$. The lateral migration of the magma en route is minimal in comparison with its vertical migration. This implies the vent location at the surface is a good approximation to the location of melt extraction at depth, i.e. the magma footprint $[42,54,108]$. The important implication of this behaviour is that interactions between magma and pre-existing structures are expected within the magma footprint area [54, 108]. Correlation between preexisting faults and dykes are often recognized in volcanic fields [10, 53, 108, 113-115]. The likelihood of channelization of magma by a pre-existing fracture such as a fault, is preferable in the case of high-angle faults, i.e. $70-80^{\circ}$, and shallow depths [53] when the magma pressure is less than the tectonic strain taken up by faulting $[42,53]$.

These monogenetic eruptions have a wide variation in eruptive volumes. Volumetrically, two end-members types of volcanoes have been recognized [5, 109, 116]. Large-volume $(\geq 1$ $\mathrm{km}^{3}$ or polygenetic) volcanoes are formed by multiple ascent of magmas that use more or less the same conduit system over a long period of time usually ka to Ma and have complex phases of construction and destruction [86, 117-119]. The spatial concentration of melt ascents, and temporally the longevity of such systems are usually caused by the formation of magma storage systems at various levels of the crust beneath the volcanic edifices [120-122]. In this magma chamber stalled magma can evolve by differentiation and crystallization in $\mathrm{ka}$ time scales [123]. On the other hand, a small-volume ( $\leq 1 \mathrm{~km}^{3}$ or monogenetic) volcano is referred to as "[it] erupts only once" [e.g. 116]. The relationship between large and small volume magmatic systems and their volcanoes is poorly understood [1, 5, 109, 124-127]. Nevertheless, there is a wide volumetric spectrum between small and large (monogenetic and polygenetic) volcanoes and these two end-members naturally offer the potential for transition types of volcanoes to exist. An ascent event is not always associated with a single batch of magma, but commonly involves multiple tapping events (i.e. multiple magma batches), creating a diverse geochemical evolution over even a single eruption [9, 11, 16-17, 45, 128]. Multiple melt batches involved in a single event may be derived from the mantle directly or from some stalling magma ponds around high density contrast zones in the lithosphere such as the upper-mantle/crust boundary $[9,128]$ and/or around the ductile/brittle boundary zone in the crust [16].

A volcanic eruption on the surface is considered to be a result of a successful coupling mechanism between internal processes, such as melt extraction rate and dyke interaction en-route to the surface $[50,76,110]$, and external processes, such as local and regional stress fields in 
the crust $[42,109]$. Therefore, the spatial and temporal location of a volcanic event represents the configuration of the magmatic system at the time of the eruption. However, mantle-derived, usually primitive magmas feeding monogenetic magmatic systems are uncommon and rarely erupt individually. They tend to concentrate in space forming groups of individual volcanoes or clusters [7, 24, 129-130], and in time constitute volcanic cycles [39, 42, 131-132]. The spatial component of volcanism is dependent on the susceptibility of magma to be captured by pre-existing structures such as faults [10, 53-54], and the regional stress field at the time of the melt ascent $[7,43,109,133]$. Temporal controls are also significantly influenced by internal and external forces. The monogenetic magmatic systems can be classified into two groups [131, 134]. The volume-predictable systems [134-135] are internallycontrolled, i.e. it is magmatically-controlled [42]. In this system, an eruption on the surface is a direct result of successful separation of melt from a heterogeneous mantle, which is independent from the tectonics. Therefore, the total volume of magma erupting at the surface is usually a function of magma production rates of the system and repose time since the previous eruption [42]. These magmatic systems are usually characterized by high magma flux, promoting frequent dyke injections and high magmatic contribution to local extensional strain accumulation. These could trigger earthquakes, faulting and surface deformations, such as ruptures, associated with the high rates of magma intrusions [111, 136] similar to the intrusion at tensional rift zones [e.g. 137-138]. Magma ascent is often dominated by the regional-scale direction of stress rather than the location of pre-existing faults and topography [111]. In contrast, the time-predictable magmatic system [131, 139] is a passive by-product of tectonic shear-triggered melt extraction $[42,95,103,131]$. Without tectonic forces, the melt would not be able to be extracted from partially molten aggregates [42]. Consequently, this magma generation process is externally- or tectonically-controlled [42]. The overall magma supply of these volcanic fields is generally low. Magmatic pressure generated by the magma injections are commonly suppressed by lithostatic pressure, resulting in a greater chance of interaction between magma and pre-existing structures in the shallow crust [53, 111, 140]. Dyke capturing commonly takes place if the orientation of the dyke plane is not parallel with the direction of maximum principal stress, causing vent alignments and fissure orientation to not always be perpendicular with the least principal stress direction $[42,54]$.

Restriction of magma ascent to a small area usually results in monogenetic volcanoes forming volcanic fields in a well-defined geographic area. These eruptions normally take place from hours to decades resulting in the accumulation of small-volume eruptive products on the surface predominantly from basaltic magmas. However, a monogenetic volcanic field could experience monogenetic eruptions over time scales of Ma [5, 39, 141-142] and the lifespan is characterized by waxing and waning stages of volcanism and cyclic behaviour [39, 108]. In a single monogenetic volcanic field, tens to thousands of individual volcanoes may occur [143] with predominantly low $\mathrm{SiO}_{2}$ content eruptive products ranging from ca. $40 \mathrm{wt} \%$ up to $60 \mathrm{wt} \%[16,40,128,144-146]$. However, monogenetic volcanism does not depend on the chemical composition because there are similar small-volume monogenetic volcanoes that have been erupted from predominantly silica-rich melt such as Tepexitl tuff ring, Serdán-Oriental Basin, Mexican Volcanic Belt, Mexico [147] or the Puketarata tuff ring, Taupo Volcanic Zone, New Zealand [148]. 


\section{Construction of monogenetic volcanoes}

The ascent of magma from source to surface usually involves thousands of interactions between external and internal processes, thus the pre-eruptive phase works like an open system. Once single or multiple batch(es) of magma start their ascent to the surface, there is continuous degassing and interactions with the environment at various levels en route. On the surface, the ascending magma ascent can feed a volcanic eruption that can be explosive or effusive. Important characteristics of the volcanic explosion are determined at shallow depth $(\leq 1-2 \mathrm{~km})$ by the balance between external and internal factors such as chemical composition or availability of external water. The volcanic eruptions are usually characterised by discrete eruptive and sedimentary processes that are important entities of the formation and emplacement of a monogenetic vent itself.

\subsection{Internal versus external-driven eruptive styles}

The current classification of volcanic eruptions is based mainly on characteristics such as magma composition, magma/water mass ratio, volcanic edifice size and geometry, tephra dispersal, dominant grain-size of pyroclasts and (usually eye-witnessed) column height [e.g. 149]. If the ascending melt or batches of melts reach the near-surface or surface region, it will either behave explosively or intrusively/effusively. Explosive magma fragmentation is triggered either by the dissolved magmatic volatile-content [150] or by the thermal energy to kinetic energy conversion and expansion during magma/water interactions [151-152], producing distinctive eruption styles. These eruption styles can be classified on the basis of the dominance of internal or external processes.

Internally-driven eruptions are promoted by dissolved volatiles within the melt that exsolve into a gas-phase during decompression of magma [153-155]. The volatiles are mainly $\mathrm{H}_{2} \mathrm{O}$ with minor $\mathrm{CO}_{2}$, the latter exsolving at higher pressure and therefore greater depths than $\mathrm{H}_{2} \mathrm{O}$ [e.g. 156]. Expansion of these exsolved gases to form bubbles in the magma suddenly lowers the density of the rising fluid, causing rapid upward magma acceleration and eventually fragmentation along bubble margins [150, 155, 157-159]. The growth of gas bubbles by diffusion and decompression in the melt occurs during magma rise, until the volume faction exceeds $70-80 \%$ of the melt, at which point magma fragmentation occurs [160-161]. Magmas with low $\mathrm{SiO}_{2}$ contents, such as basalts and undersaturated magmas have low viscosity, allowing bubbles to expand easily in comparison to andesitic and rhyolitic magmas. Thus these low-silica magmas generate mild to moderate explosive types of eruptions such as Hawaiian [e.g. 162], Strombolian [e.g. 153], violent Strombolian [e.g. 163] and in very rare instances sub-Plinian types [e.g. 164, 165]. There is a conceptual difference between Hawaiian and Strombolian-style eruptions because in the former case magmatic gases rise together with the melt [154], whereas in Strombolian-style eruptions an essentially stagnant magma has gas slugs that rise and bubble through it - generating large gas slug bursts and foamcollapse at the boundary of the conduit [153, 166]. According to the rise speed-dependent model, bubbles form during magma ascent [150], while in the case of the foam collapse model, bubbles up to $2 \mathrm{~m}$ in diameter are generated deeper, in the upper part of a shallow 
magma chamber, based on acoustic measurements at the persistently active Stromboli volcano in the Aeolian Islands, Italy [153].

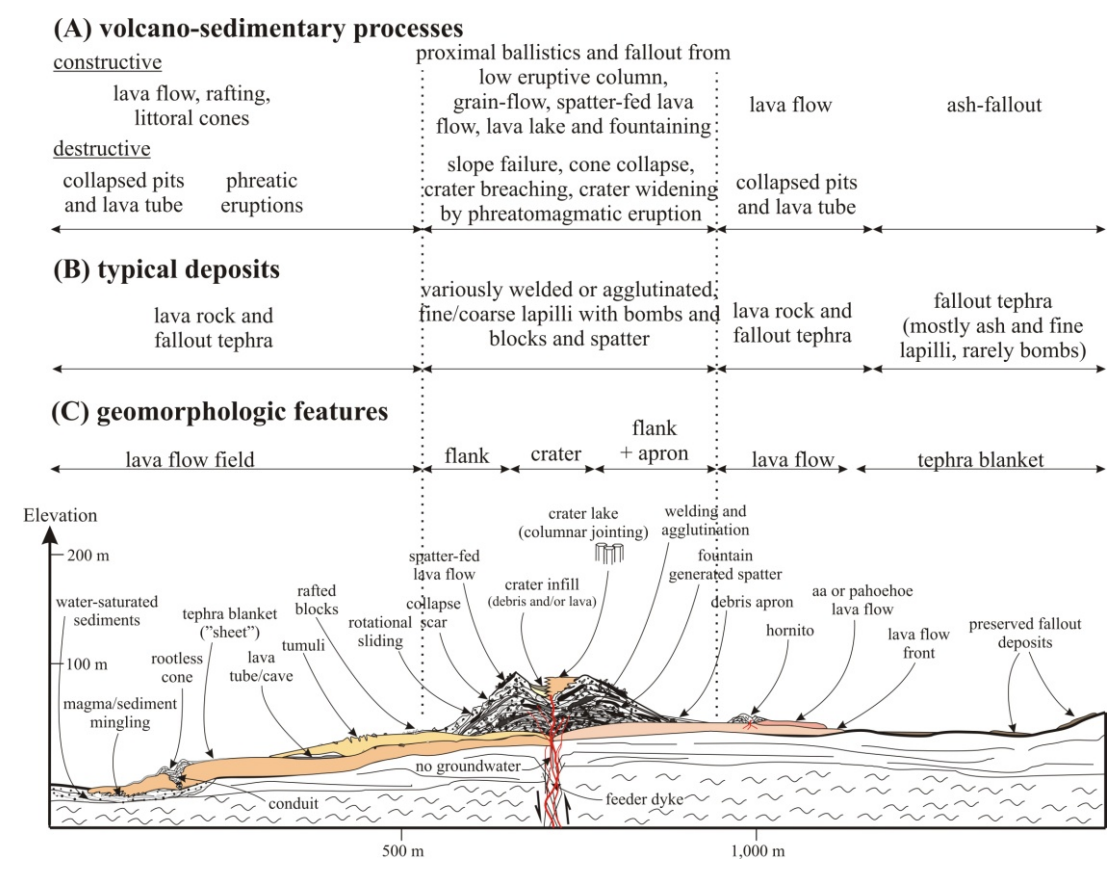

Figure 2. Schematic cross-section through a spatter cone showing the typical volcano-sedimentary processes and geomorphologic features.

A Hawaiian eruption results from one of the lowest energy magma fragmentation that are driven mostly by the dissolved gas content of the melt, which produces lava fountaining along fissures or focussed fountains up to $500 \mathrm{~m}$ in height [150,162, 167-168]. The lava fountaining activity ejects highly deformable lava 'rags' at about $200-300 \mathrm{~m} / \mathrm{s}$ exit velocity with an exit angle that typically ranges between $30-45^{\circ}$ from vertical [169-170]. The nature and the distribution of the deposits associated with lava fountaining depend on the magma flux and the magma volatile content [162, 171-172]. Magmatic discharge rates during lava fountain activity range typically between 10 and $10^{5} \mathrm{~kg} / \mathrm{s}[162,166]$. The duration of typical lava fountaining activity may last only days or up to decades. An example for the former is Kilauea Iki, which erupted in 1959 [167, 170], while an example for the latter is $\mathrm{Pu}^{\prime} \mathrm{u}^{\prime} \mathrm{O}^{\prime} \mathrm{o}-\mathrm{Ku}$ paianaha, which began to erupt in 1983 [173]. Both are located on the Kilauea volcano in the Big Island of Hawaii, USA. Pyroclasts generated by lava fountaining are coarsely fragmented clots of magma which do not travel far from and above the vent [170-171]. They commonly land close to the vent and weld (i.e. mechanical compaction of fluid pyroclasts due to overburden pressure), agglutinate (i.e. flattening and deformation of fluid pyroclasts) or coalesce (i.e. homogenously mixed melt formed by individual fluidal clots) due to the high 
emplacement temperature of fragmented lava lumps on the depositional surface and/or the fast burial of lava fragments, which can retain heat effectively for a long time [171-172, 174]. The degree of welding and agglutinating of lava spatter is dependent on the [170-172, 174-175]:

1. accumulation rate and thickness of the deposit,

2. duration of eruption,

3. lava fountain height,

4. initial temperature determined by the magma composition,

5. heat loss rate, as well as

6. the grain size.

As a result of the limited energy involved in this type of magma fragmentation, the coarsely fragmented lava clots are transported ballistically, while the fines are transported by a low eruption column, as in the case of Plinian eruptions $[162,176]$. The fragments tend to accumulate in proximal position, forming a cone-shaped pile, a spatter cone (Figure 2), which is built up by alternation of lava spatter and lava fountain-fed flows $<100 \mathrm{~m}$ in diameter and a few tens of meters in height [170-172, 177-179].

Based on the grain size and the limited areal dispersion of tephra associated with typical Strombolian-style eruptions, it is considered a result of a mild magma fragmentation [149, 155]. However, larger volumes of tephra are produced than Hawaiian-style eruptions [159, 180]. Tephra production is derived from relatively low, non-sustained eruption columns $[111,153,158,181]$. Individual explosions last $<1 \mathrm{~min}$ and eject 0.01 to $100 \mathrm{~m}^{3}$ of pyroclasts to $<200 \mathrm{~m}$ in height with an exit velocity of particles of 3-100 m/s [180]. The magma discharge rate of $10^{3}$ to $10^{5} \mathrm{~kg} / \mathrm{s}$ is based on historical examples of volcanoes erupted from water-rich, subduction-related magma [156]. The near surface fragmentation mechanism and limited energy released in a single eruption results in coarse lapilli-to-block-sized pyroclasts, predominantly between 1 and $10 \mathrm{~cm}$ in diameter, accumulating in close proximity to the vent [84, 182-183]. The exit velocity and angle of ballistic trajectories of particles of $20-25^{\circ}$ determines the maximum height of the edifice and produces a limited size range of clasts in these volcanic edifices [184-185]. The repetition of eruptions produces individual, moderately-tohighly vesicular pyroclasts, called scoria or cinder, that do not agglutinate in most situations, but tend to avalanche downward forming talus deposits on the flanks of the growing cone [185-187]. Due to the mildly explosive nature of the eruptions, and the relatively stable pyroclast exit angles and velocity, a well-defined, conical-shaped volcano is constructed and is commonly referred to as a scoria or cinder cone (Figure 3). These cones have a typical basal diameter of 0.3 to $2.5 \mathrm{~km}$, and they are up to $200 \mathrm{~m}$ high [153, 179, 182, 185, 188-189].

A more energetic magma fragmentation than is normally associated with Strombolian-activity cause violent Strombolian eruptions $[163,190]$. In the 'normal' Strombolian-style eruptions, the magma is separated by gas pockets, which rise periodically in the magma through the conduit forming a coalescence of gas pockets, or a slug flow regime [153]. When the gas 
segregation increases, the eruptions become more explosive due to episodic rupture of liquid films of large bubbles, causing alternation of the flow regime from slug flow to churn flow, which is a typical characteristic of the violent Strombolian activity [163]. Based on numerical simulations, the increases in the gas flux, which creates the "churn flow", is caused by factors such as an increased length of conduit, the change in magma flux from $10^{4}$ to $10^{5}$ $\mathrm{kg} / \mathrm{s}$, the gas content, and/or the ascent speed variations that allow magma to vesiculate variably within the conduit [156, 163, 191]. Larger energy release during more explosive eruptions produces a higher degree of fragmentation, and hence finer-grained, ash-lapilli dominated beds [191], as well as higher eruption columns $(<10 \mathrm{~km})$ that disperse tephra efficiently over longer distances [83, 163].

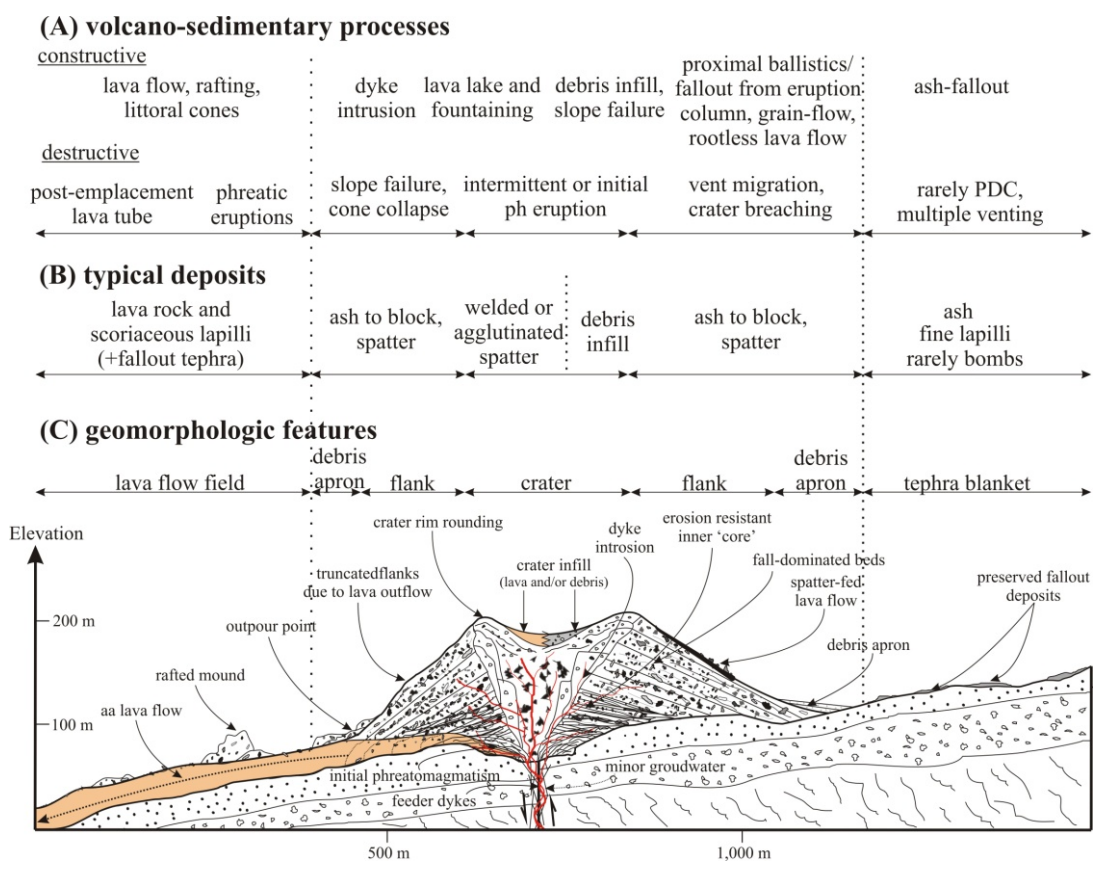

Figure 3. Schematic cross-section through a typical scoria cone showing the typical volcano-sedimentary processes and geomorphologic features. Abbreviations: PDC - pyroclastic density current, ph - phreatomagmatic eruption.

Externally-driven fragmentation occurs when the melt interacts with external water leading to phreatomagmatic or Surtseyan-style eruptions [152, 192-195]. These explosive interactions take place when magma is in contact with porous- or fracture-controlled groundwater aquifers or surface water [151, 194, 196-202]. In special cases when explosive interactions take place between lava and lake, sea water or water-saturated sediments, littoral cone [203-204] and rootless cone [205-208] are generated. Processes and eruption mechanisms associated with these eruptions are not discussed in the present chapter. The evidences of the role of water in the formation of tuff rings and maar have been proofed by many studies [e.g. 152, 
201, 209]. However, there are similar eruptive processes and eruption styles have been described from eruptions of silica-undersaturated magmas (e.g. foidite, melilitite and carbonatite) in environments, where the role of external water on the eruptive style is limited [e.g. 210-212].

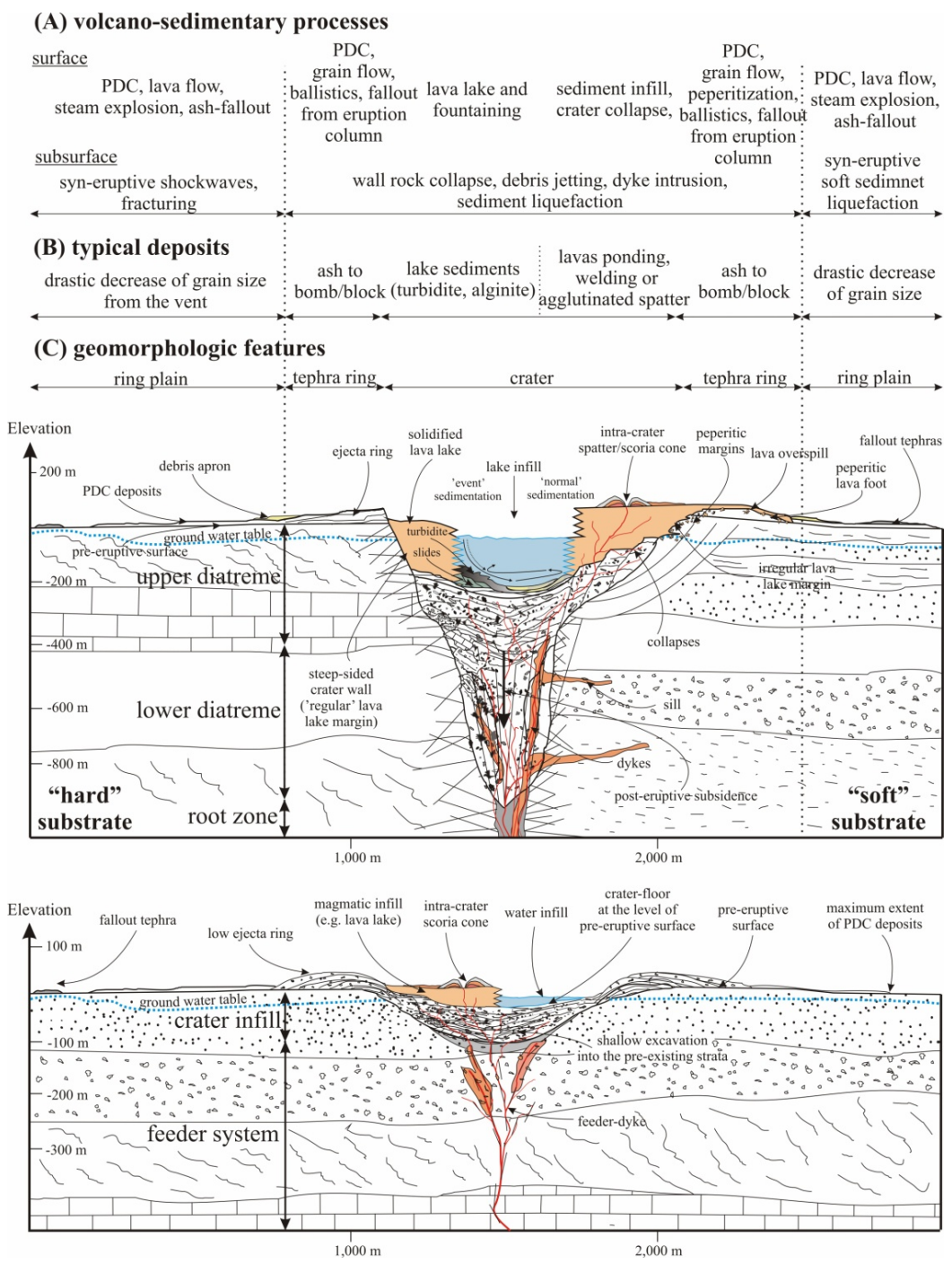

Figure 4. Schematic cross-sections through a maar-diatreme (top figure) and a tuff ring (bottom figure) showing the typical volcano-sedimentary processes and geomorphologic features. Note that the left-hand side represents the characteristics of a maar-diatreme volcano formed in a hard-substrate environment, while the right-hand side is the soft rock environment. Abbreviations: PDC - pyroclastic density current. 
Phreatomagmatic eruptions (rarely called Taalian eruptions) are defined by some as being in subaerial environments [194]. These eruptions may produce a series of volcanic craters which vary in size between $0.1 \mathrm{~km}$ and $2.5 \mathrm{~km}$ in diameter [213]. The largest ones are very likely to be generated by multiple eruptions forming amalgamated craters such as Lake Coragulac maar, Newer Volcanics Province, south-eastern Australia [214] and/or formed in specific environment such as Devil Mountain maar, Seward Peninsula, Alaska [215]. The fragmentation itself is triggered by a molten fuel-coolant interaction (MFCI) processes requiring conversion of magmatic heat to mechanical energy [151, 193-194, 216-220]. The MFCI proceeds as follows [151, 220]:

1. coarse premixing of magma and water producing a vapour film between fuel and coolant,

2. collapse of the vapour film, generating fragmentation of magma and producing shock waves,

3. rapid expansion of superheated steam to generate thermohydraulic explosions, as well as

4. post-eruption (re)fragmentation of molten particles.

In some cases the MFCI process is self-driven and, after the initial interactions, the fragmentation does not involve any other processes [194, 196, 217, 221-222]. The series of eruptions may excavate a crater that cuts into the pre-existing topography, forming a hole-in-theground structure called a maar (Figure 4) [152]. If the explosion locus stays at shallow depths, the resulting volcano is tuff ring, which has a crater floor normally near the preeruptive surface (Figure 4) [223]. Both eruptions result in a surface accumulation of tephra by fallout and pyroclastic density currents, mostly base surges, forming a usually circular ejecta ring around the crater [51, 58, 195, 200, 202, 224-228]. These eruptions produce pyroclastic deposits that have a diversity of juvenile pyroclasts (e.g. various shape, grain-size, vesicularity and microlite content) and variety of accidental lithic clasts derived from the underlying strata [52, 79, 229-231]. Pyroclastic successions of phreatomagmatic volcanoes can form coarse grained, chaotic breccias related to vent construction, conduit wall collapse or migration, as well as well-stratified, lapilli and ash-dominated beds with various degrees of sorting and large ballistically ejected, fluidal-shaped juvenile bombs or angular to heavily milled accidental lithic blocks [41, 59, 81, 223, 232-237]. Due to density current transportation of pyroclasts, the accumulating deposits are stratified and are commonly cross- or dunebedded [81, 229-230, 238-240]. The craters of most of these phreatomagmatic volcanoes are filled by either post-maar eruptive products such as solidified lava lakes commonly showing columnar jointing and/or intra-crater scoria/spatter cones [81, 241-244], or non-volcanic sediments, such as lacustrine alginate, volcaniclastic turbidite deposits [195, 245-250].

Surtseyan-style eruptions occur when the external water is 'technically' unlimited during the course of the eruption when eruptions occur through a lake or the sea [222, 251-254]. In contrast with phreatomagmatic eruptions, Surtseyan-style eruptions require a sustained bulk mixing of melt and coolant, which generates more abrupt and periodic eruptions [194, 196]. During Surtseyan-style eruptions, water is flashed to steam which tears apart large fragments 
of the rising magma tip [222, 252, 254-256]. This process is far less efficient than self-sustained typical MFCI and causes a near continuous ejection of tephra [194]. This tephra feeds subaqueous pyroclastic density currents, which build up a subaqueous volcanic pile that may emerge to become an island in the course of the eruption [222, 253-254, 257-259], as was the case during the well-documented eruption of Surtsey tuff cone, Vestmannaeyjar Islands, Iceland in 1963-1967 AD [260-261]. After emergence, a conical volcano can cap the edifice and build a typical steep-sided tuff cone (Figure 5). The tuff cone gradually grows by rapidly expelled and frequent (every few seconds) tephra-laden jets that eject muddy, water-rich debris, which may initiate mass flows later on in the inner-crater wall and on the outer, steepening flank of the growing cone [253, 260, 262-265]. These shallow explosions eventually produce a cone form, although it often has irregular geometry with a breached or filled crater by late-stage lava flows or asymmetric crater rim [223, 234, 259,264]. The diameters of craters of these tuff cones are comparable to the tuff rings and maars, but the elevation of the crater rims are higher, reaching up to $300 \mathrm{~m}$ [223]. Monogenetic volcanoes that formed by Surtseyan-eruptions typically have no diatreme below their crater, however, some recent research suggested that diatremes may exist beneath a few tuff cones, such as Saefell tuff cone, south Iceland [266] or Costa Giardini diatreme, Iblean Mountains, Sicily [267].

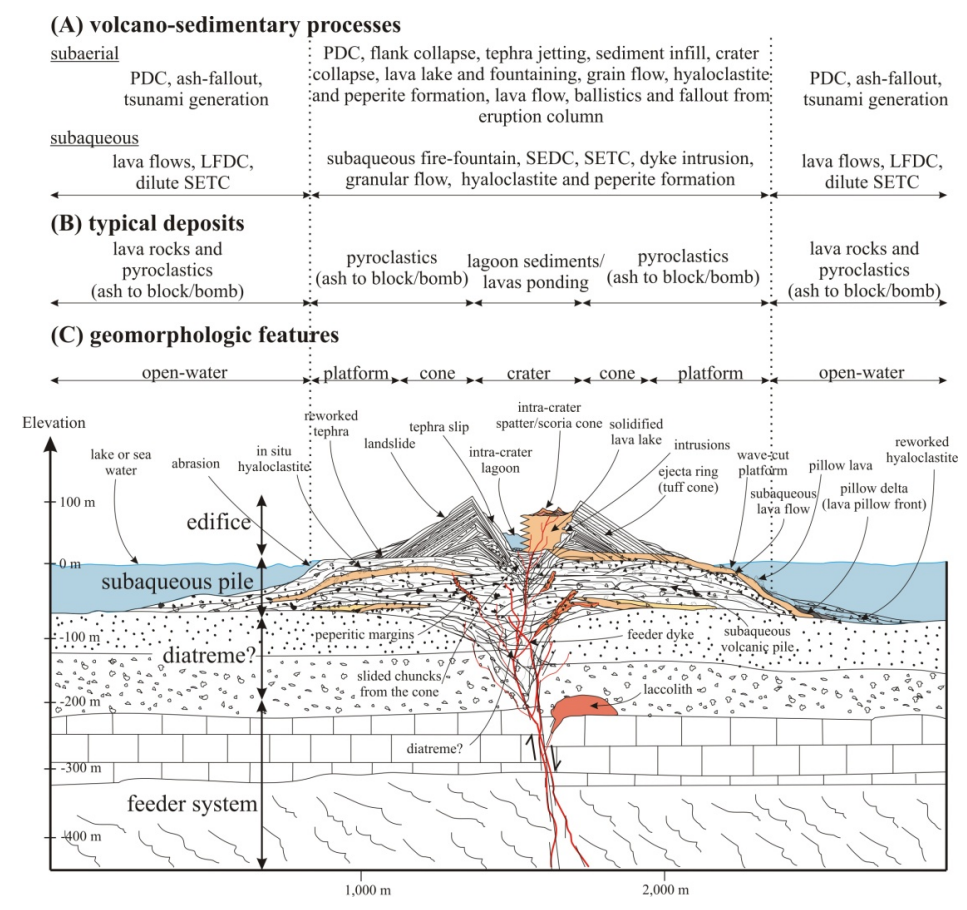

Figure 5. Schematic cross-section through a tuff cone showing the typical volcano-sedimentary processes and geomorphologic features. Abbreviations: PDC - pyroclastic density current, SEDC - subaqueous eruption-fed density current, SETC - subaqueous eruption-fed turbidity current, LFDC - lava flow-fed density current 


\subsection{Spectrum of basaltic monogenetic volcanoes}

As documented above, five types of monogenetic volcanoes are conventionally recognized $[177,179,223]$ :

1. lava spatter cones,

2. scoria or cinder cones,

3. maars or maar-diatremes,

4. tuff rings and

5. tuff cones.

This classification is primarily based on the morphological aspects and dominant eruption styles of these volcanoes. Furthermore, there is a strong suggestion that a given eruption style results in a given type of volcanic edifice, e.g. Strombolian-style eruptions create scoria cones [e.g. 111, 182]. The conventional classification also fails to account for the widely recognized diversity or transitions in eruption styles that may form 'hybrid' edifices, e.g. intra-maar scoria cones with lava flows or scoria cones truncation by late stage phreatomagmatism [229, 244, 268-271]. The variability in the way a monogenetic volcano could be constructed also means that the conventional classification hides important details of complexity that may be important from volcanic hazard perspective (e.g. a volcano built up by initial phreatomagmatic eruptions and later less dangerous Strombolian eruptions). The diversity of pyroclastic successions relates to fluctuation of eruption styles that may be triggered by changing conduit conditions, such as geometry, compositional change, and variations in both magma and/or ground water supply [41, 52, 150, 163, 272-273]. Due to the abundance of intermediate volcanoes, a classification scheme is needed, where the entire eruptive history can be parameterized numerically.

In the present study, the construction of a small-volume volcano is based on two physical properties (Figure 6):

1. eruption style and associated sedimentary environment during an eruption and

2. number of eruption phases.

A given eruption style is a complex interplay between internal and external controlling parameters at the time of magma fragmentation. The internally-driven eruption styles are, for example, controlled by the ascent speed, composition, crystallization, magma degassing, number of magma batches involved, rate of cooling, dyke and conduit wall interactions, depth of gas segregation and volatile content such as $\mathrm{H}_{2} \mathrm{O}, \mathrm{CO}_{2}$ or $\mathrm{S}[9,11,17,111,128,150,154-156,163,188$, 191, 274-276]. These processes give rise to eruption styles in basaltic magmas that are equivalent to the Hawaiian, Strombolian and violent Strombolian eruption styles. However, due to the small-volume of the ascending melt, the controls on magma fragmentation are dominated by external parameters, including conduit geometry, substrate geology, vent stability/migration, climatic settings, and the physical characteristics of the underlying aquifers $[39,82,234$, 277-279]. Another important parameter in the construction of a monogenetic volcanic edifice is the number of eruptive phases contributing to its eruption history (Figure 6). The complexity 
of a monogenetic landform increases with increasing number or combination of eruptive phases. These can be described as "single", "compound" and "complex" volcanic edifices or landforms [280-281]. In this classification, the volcano is the outcome of combinations of eruption styles repeated by $m$ phases. For example, a one-phase volcano requires only one dominant eruption mechanism during its construction. Due the single eruption style, the resulting volcano is considered to be a simple landform with possibly simple morphology. However, monogenetic volcanoes tend to involve two or multiple phases (Figure 6). Their construction requires two or more eruption styles and the result is a compound or complex landforms respectively, e.g. maar-like scoria cones truncated by late stage phreatomagmatic eruptions [e.g. $82,270,282$ ] or a tuff cone with late-stage intra-crater scoria cone(s) [e.g. 265, 283]. These phases may occur at many scales from a single explosion (e.g. a few $\mathrm{m}^{3}$ ) to an eruptive unit comprising products of multiple explosions from the same eruption style.

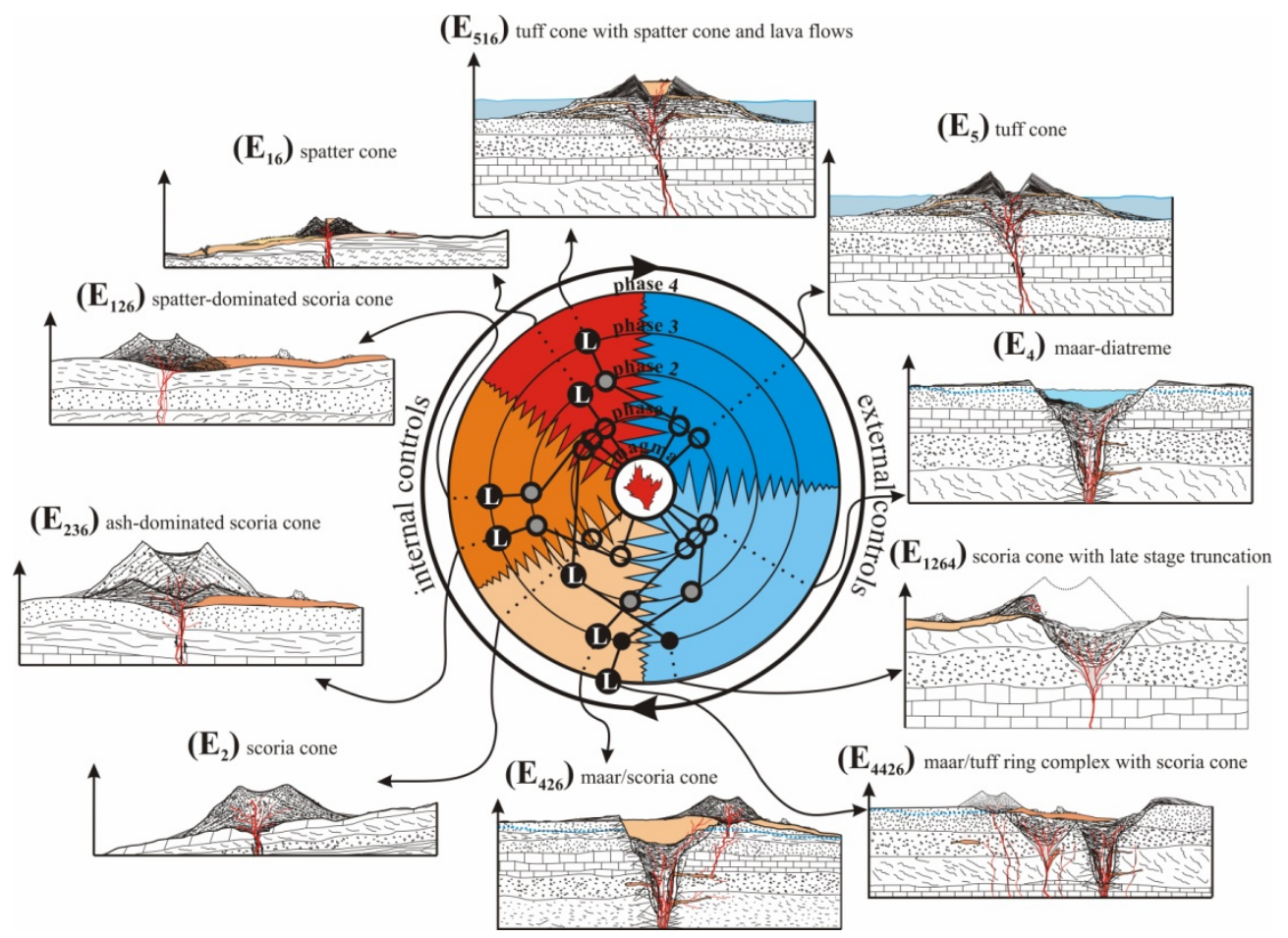

Figure 6. Eruption history (E) defined by a spectrum of eruptive processes determined by internal and external parameters at a given time. The initial magma (in the centre of the graph in red) is fragmented by the help of internal and external processes which determine the magma fragmentation mechanism and eruption style (phase 1). If a change (e.g. sudden or gradual exhaustion of groundwater, shift in vent position or arrival of new magma batch) occurs, it will trigger a new phase (phase 2, 3, 4,.., n); moving away from the pole of the diagram) until the eruption ceases. Note that black circles with white "L" mean lava effusion. If the eruption magma is dominantly basaltic in composition, the colours correspond to Surtseyan (dark blue), phreatomagmatic (light blue), Strombolian (light orange), violent Strombolian (dark orange) and Hawaiian (red) eruption styles. 
To put this into a quantitative context, this genetic diversity can be expressed as set of matrices, similar to Bishop [280]. In Bishop [280], the quantitative taxonomy is represented by matrices of volcanic landforms that were based on surface morphologic complexity and eruption sequences. The role of geomorphic signatures is reduced due to the fact that in the case of an eruption centre built up by multiple styles of eruptions, not all eruption styles contribute to the geomorphology. For example, a scoria cone constructed by tephra from a Strombolian-style eruption, might be destroyed by a late stage phreatomagmatic eruption, as documented from Pinacate volcanic field in Sonora, Mexico [82, 284] and Al Haruj in Libya [282]. In these cases, the final geomorphologies resemble to maar craters, but the formation such volcanoes are more complex than a classical, simple maar volcano. In the proposed classification scheme, the smallest genetic entity (i.e. eruption style and their order) was considered to define the eruption history of a monogenetic volcano quantitatively. Considering only the typical, primitive basaltic composition range $\left(\mathrm{SiO}_{2} \leq 52 \%\right.$ w.t. $)$, internally-driven eruption styles are the Hawaiian, Strombolian and violent Strombolian eruption styles [111]. At the other end of the spectrum, externally-driven eruption styles are the phreatomagmatic and Surtseyan-types [81, 285]. In addition, the effusive activity can also be involved in this genetic classification. The abovementioned eruption/effusion styles can build up a volcano in the following combination: $6 \times 1,6 \times 6,6 \times 6^{2}$ or $6 \times m($ or $n \times m)$ matrices, depending on the number of volcanic phases involved in the course of the eruption. This means that an eruption history $(\mathrm{E})$ of a simple volcano $\left(\mathrm{E}_{\text {simple }}\right)$ could be written as:

$$
\mathrm{E}_{\text {simple }}=\left[\begin{array}{llllll}
1 & 2 & 3 & 4 & 5 & 6
\end{array}\right]
$$

where the elements 1, 2, 3, 4 and 5 corresponds to explosive eruptions such as Hawaiian, Strombolian, violent Strombolian, Taalian (or phreatomagmatic) and Surtseyan-type eruptions, respectively, while the 6 is the effusive eruption. For a more complex eruption history involving two ( $\left.\mathrm{E}_{\text {compound }}\right)$ and multiple $\left(\mathrm{E}_{\text {complex }}\right)$ eruption styles can be written as:

$$
\mathrm{E}_{\text {compound }}=\left[\begin{array}{llllll}
11 & 12 & 13 & 14 & 15 & 16 \\
21 & 22 & 23 & 24 & 25 & 26 \\
31 & 32 & 33 & 34 & 35 & 36 \\
41 & 42 & 43 & 44 & 45 & 46 \\
51 & 52 & 53 & 54 & 55 & 56 \\
61 & 62 & 63 & 64 & 65 & 66
\end{array}\right]
$$

For instance, a monogenetic volcano with an eruption history of fire-fountain activity associated with a Hawaiian-type eruption and effusive activity could be described as having a compound eruption history (or $\mathrm{E}_{16}$ in Figure 6). While an example of a monogenetic volcano with a complex eruption history could be a volcanic edifice with a wide, 'maar-crater-like' morphology, but built up from variously welded or agglutinated scoriaceous pyroclastic rock units (e.g. $\mathrm{E}_{1264}$ in Figure 6), similar to Crater Elegante in Pinacate volcanic field, Sonora, Mexico [284]. In some cases, gaps, paucity of eruptions or opening of a new vent site after 
vent migration between eruptive phases is observed/expected based on reconstructed stratigraphy [e.g. 52, 279] and geochemistry [e.g. 9, 286]. In this classification system, the recently recognized polymagmatic or polycyclic behaviour of monogenetic volcanoes, e.g. an eruption fed by more than one batch of magma with distinct geochemical signatures [17, 23, 287], can be integrated. For example, the volcano could be $\mathrm{E}_{44}$ if the controls on eruption style remained the same or $\mathrm{E}_{42}$ if that chemical change is associated with changes in eruption style. The number of rows and columns in these matrices could be increased until all types of eruption style are described numerically, thus an $\mathrm{n} \times \mathrm{m}$ matrix is created. Increasing the number of volcanic phases will increase the range of volcanoes that could possibly be created. Of course, the likelihood of various eruptive combinations described by these matrices is not the same because there are 'unlikely' (e.g. $\mathrm{E}_{665}$ ) and 'common' eruptive scenarios (e.g. $\mathrm{E}_{412}$ ).

$$
\mathrm{E}_{\text {complex }}=\left[\begin{array}{cccccc}
111 & 112 & 113 & 114 & 115 & 116 \\
\cdot & & & & & \cdot \\
\cdot & & & & & \cdot \\
\cdot & & & & & \cdot \\
661 & 662 & 663 & 664 & 665 & 666
\end{array}\right]
$$

In summary, a volcano from monogenetic to polygenetic can be described as a matrix with elements corresponding to discrete volcanic phases occurring through its evolution. The major advantage of these matrices is that their size is infinite $(n \times m)$, thus an infinite number of combinations of eruption styles could be described (Figure 6). In this system each volcano has a unique eruptive history, in other words, each volcano is a unique combination of $n$ number of eruption styles through $m$ number of volcanic phases (Figure 6). This matrixbased classification scheme helps to solve terminological problems and to describe volcanic landforms numerically. For example, the diversity of scoria cones from spatter-dominated to ash-dominated end-members $[68,288]$ cannot be easily expressed within the previous classification scheme. This completely quantitative coding of volcanic eruption styles into matrices could be used for numerical modelling or volcanic hazard models, e.g. spatial intensity of a given eruption style.

\section{Geomorphology of monogenetic volcanoes}

\subsection{Historical perspective}

The combination of eruption styles (listed above) and related sedimentary processes are often considered to be the major controlling conditions on a monogenetic volcano's geomorphic evolution [84]. Thus, the quantitative topographic parameterization of volcanoes is an important source of information that helps to reveal details about their growth, eruptive processes and associated volcanic hazards and its applicable to both conical [119, 190, 289-292] and non-conical volcanoes [199, 293]. These methods are commonly applied to both 
polygenetic [119, 289, 294-297] and monogenetic volcanic landforms [68-69, 298-299]. Morphometric measurements on monogenetic volcanoes began with the pioneering work of Colton [300], who noticed a systematic change in the morphology of volcanic edifices over time due to erosional processes such as surface wash and gullying. A surge of research in volcanic morphometry, focused mostly on scoria cones, occurred from the 1970s to 1990s, when the majority of morphometric formulae were established and tested [70-71, 84, 179, 185, 199, 213, 223, 293, 301-304]. This intense period of research was initiated by National Aeronautics and Space Administration (NASA) in the 1960s and 1970s due to an increasing interest in extraterrestrial surfaces that could be expected to be encountered during landings on extraterrestrial bodies such as the Moon or Mars [e.g. 33]. Additional interests were to understand magma ascent, the lithospheric settings of extraterrestrial bodies, the evolution of volcanic eruptions, the geometry of volcanoes in different atmospheric conditions, surface processes and seeking $\mathrm{H}_{2} \mathrm{O}$ in extraterrestrial bodies [30, 33, 305-308]. Given the lack of field data from extraterrestrial bodies, many parameters that were able to be measured remotely, such as edifice height $\left(\mathrm{H}_{\mathrm{co}}\right)$, basal $\left(\mathrm{W}_{\mathrm{co}}\right)$ and crater diameters $\left(\mathrm{W}_{\mathrm{cr}}\right)$ were introduced. There were measured manually from images captured by Mariner and Viking orbiter missions [e.g. 33] and Luna or Apollo missions for the Moon [e.g 309] in order to compare these data with the geometry of volcanic landforms on the Earth [e.g. 179, 293]. Dimensions, such as crater diameter, were measured directly from these images, while the elevation of the volcanic edifices was estimated from photoclinometry (i.e. from shadow dimensions of the studied landform) [33, 309-310]. Because elevation measurements were indirect, the horizontal dimensions such as $W_{c o}$ and $W_{c r}$ were preferred in the first morphometric parameterization studies [179]. The increased need for Earth analogues led to intense and systematic study of terrestrial small-volume volcanoes $[179,185,189,293]$. The terrestrial input sources, such as topographic/geologic maps and field measurements, were more accurate than the extraterrestrial input resources; however, they were still below the accuracy required (i.e. the contour line intervals of $\geq 20 \mathrm{~m}$ were not dense enough to capture the topography of a monogenetic volcano having an average size of $\leq 1500-2000 \mathrm{~m}$ horizontally and of $\leq 100-150$ $\mathrm{m}$ vertically). The extensive research on monogenetic volcanoes identified general trends regarding edifice growth, eruption mechanism and subsequent degradation [71, 84, 185, 293]. In addition, morphometric signatures were recognized that associated a certain type of monogenetic volcanic landform with the discrete eruption style that formed it. The morphometric signatures of Earth examples were then widely used to describe and identify monogenetic volcanoes on extraterrestrial bodies such as the Moon and Mars [179]. Basic morphometric parameters were calculated and geometrically averaged to get morphometric signatures for four types of terrestrial, monogenetic volcanoes [179], including spatter cones $\left(\mathrm{W}_{\mathrm{co}}=0.08 \mathrm{~km}, \mathrm{~W}_{\mathrm{cr}} / \mathrm{W}_{\mathrm{co}}=0.36 \mathrm{~km}\right.$ and $\left.\mathrm{H}_{\mathrm{co}} / \mathrm{W}_{\mathrm{co}}=0.22 \mathrm{~km}\right)$, scoria cones $\left(\mathrm{W}_{\mathrm{co}}=0.8 \mathrm{~km}, \mathrm{~W}_{\mathrm{cr}} / \mathrm{W}_{\mathrm{co}}\right.$ $=0.4 \mathrm{~km}$ and $\left.\mathrm{H}_{\mathrm{co}} / \mathrm{W}_{\mathrm{co}}=0.18 \mathrm{~km}\right)$, as well as maars and tuff rings $\left(\mathrm{W}_{\mathrm{co}}=1.38 \mathrm{~km}, \mathrm{~W}_{\mathrm{cr}} / \mathrm{W}_{\mathrm{co}}=0.6\right.$ $\mathrm{km}$ and $\mathrm{H}_{\mathrm{co}} / \mathrm{W}_{\mathrm{co}}=0.02 \mathrm{~km}$ ). These morphometric signatures are still used in landform recognition [e.g. 31, 311].

In terrestrial settings, the morphometric studies of monogenetic volcanoes in volcanic fields and on polygenetic volcanoes have targeted 
1. the characterization of the long-term and short-term evolution of magmatic systems [39, $42,131,134]$,

2. understanding of eruption mechanisms and processes [84, 182, 185, 312-314],

3. expression of tectonic influences on edifice growth [298, 315-316],

4. dating of conical landforms such as scoria or cinder cones [189, 304, 317-320],

5. examination of erosion processes [69-70, 290, 299, 321-327] and landscape evolution [39, $68,73,328]$,

6. reconstruction of the original size, geometry and facies architecture of polygenetic [329-332] and monogenetic edifices [291, 333-336], as well as

7. detection of climate and climate change influences on degradation [71, 324-325, 337].

Morphology quantified via morphometric parameters could be a useful tool to address some of these questions in volcanology, geology and geomorphology. The morphology of a volcanic edifice contains useful information from every stage of its evolution, including eruptive processes, edifice growth and degradation phases. However, the geomorphic information extracted through morphometric parameters often show bi- or even multi-modality, i.e. the morphometry is a mixture of primary and secondary attributes [e.g. 338]. The following section explores the dominant volcanological processes that influence the geomorphology of a monogenetic volcano.

\subsection{Syn-eruptive process-control on morphology}

The eruption styles shaping the volcanic edifices may undergo many changes during the eruption history of a monogenetic volcano (Figure 6). A given volcano's morphology and the grain size distribution of its eruptive products are generally viewed as the primary indicator of the eruption style that forms a well-definable volcanic edifice (i.e. "Stromboliantype scoria cones"). This oversimplification of monogenetic volcanoes, together with the widely used definition that "they erupts only once" [116], suggest a simplicity in terms of magma generation, eruption mechanism and sedimentary architecture. This supposedly simple and homogenous inner architecture of each classical volcanic edifice, such as spatter cones, scoria cones, tuff rings and maars, led to the identification of a "morphometric signature". The morphometric signature of monogenetic volcanoes was used in the terrestrial environment, e.g. to ascribe a relationship between morphometry and "geodynamic setting" [337], as well as extraterrestrial environments, e.g. for volcanic edifice recognition [31, 179, 339-341]. Certain types of volcanoes could be discriminated from each other based on their morphometric signature, but some general assumptions need to be made. For example,

1. the morphometric signature concept is entirely based on the assumption that a volcanic landform directly relates to a certain well-defined eruption style,

2. thus the pyroclast diversity within the edifice is minimal (i.e. homogenous), as well as 
3. the resultant volcanic landform is emplaced in a closed-system with no transitions between eruption styles, especially from externally to internally-driven eruption styles and vice versa.

Consequently, the edifice studied was believed to have a relatively simple eruption history, which is a classical definition of a "monogenetic volcano". As demonstrated above, monogenetic volcanoes develop in an open-system. This section explores the volcanological/ geological constrains of geomorphic processes responsible for the final volcanic edifice and the morphometric development of two end-member types of monogenetic volcanoes such as crater-type (4.2.1.) and cone-type edifices (4.2.2).

\subsubsection{Crater-type monogenetic volcanoes}

Crater-type monogenetic volcanoes such as tuff rings and maar volcanoes (Figure 4), are characterized by a wide crater with the floor above or below the syn-eruptive surface, respectively [81, 152, 223, 234]. Their primary morphometric signature parameters are major/ minor crater diameter and depth, crater elongation and breaching direction, volume of ejecta ring, and crater or slope angle of the crater wall [313, 342-345]. Of these morphometric parameters, the crater diameters were used widely for interpreting crater growth during the formation of a phreatomagmatic volcano. For the genetic integration of crater growth and, consequently, the interpretation of crater diameter values of terrestrial, dominantly phreatomagmatic volcanoes, there are fundamentally two end-member models.

The first model is the incremental growth model (Figure 7A). In this model, the crater's formation is related to many small-volume eruptions and subsequent mass wasting, shaping the crater and underlying diatreme [81, 151, 199-200, 209, 221, 285, 346-347]. Growth initiates when the magma first interacts with external water, possibly groundwater along the margin of the dyke intrusions, triggering molten-fuel-coolant interactions (MFCI) [192-193, 220, 348]. These initial interactions excavate a crater on the surface, while the explosion loci along the dyke gradually deepen the conduit beneath the volcano towards the water source, resulting in a widening crater diameter [199]. This excavation mechanism initiates some gravitational instability of the conduit walls, triggering slumping and wall rock wasting, contributing to the growing crater [81, 195, 199, 223, 229-230, 349]. This classical model suggests that

1. crater evolution is related to diatreme growth underneath, and

2. the crater's growth is primarily a function of the deep-seated eruption at the root zone.

However, it is more likely that the pyroclastic succession created at the rim of the crater preserves only a certain stage of the evolution of whole volcanic edifice. For instance, the possibility of juvenile and lithic fragments being erupted and deposited within the ejecta ring from a deep explosion (i.e. at the depth of a typical diatreme, about $2 \mathrm{~km}$ ) is highly unlikely. Rather than being dominated by the deep-seated eruptions, explosions can occur at variable depths within the diatreme [347]. The individual phreatomagmatic eruptions from various levels of the volcanic conduit create debris jets (solids + liquid + magmatic gases and steam), 

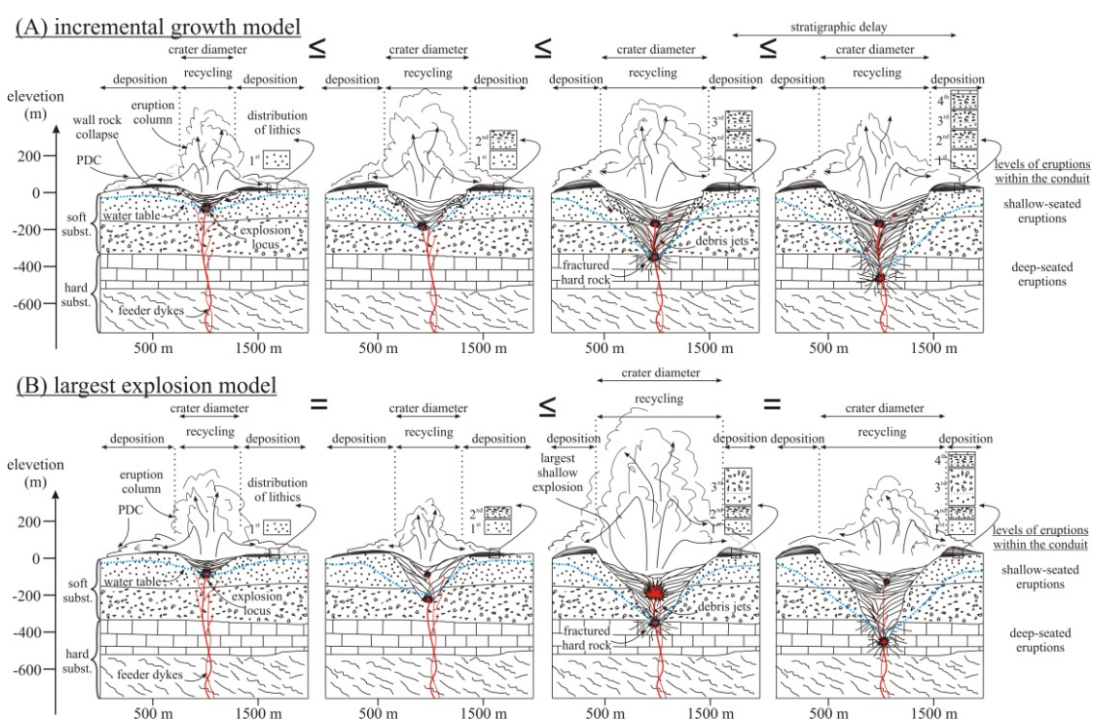

Figure 7. Crater growth envisaged by the incremental growth (A) and largest explosion models (B). In the top figure, the crater grows by each explosion and the subsequent mass wasting processes (e.g. slumping of wall rock). This results in the gradual growth of the crater and the underlying diatreme (if any). On the other hand, in the bottom figure the crater can reach its final size in the middle of the eruption history by the largest near-surface explosion and the further explosions make no contribution to its size, geometry and morphology. Abbreviations: PDC - pyroclastic density current.

which are responsible for the transportation of tephra [285, 347, 350]. Every small-volume explosion causes upward transportation of fragmented sediment in the debris jet, giving rise to small and continuous subsidence/deepening of the crater floor [198-199]. This is in agreement with stratigraphic evidence from eroded diatremes, such as Coombs Hills, Victoria Land, Antarctica [285, 350] and Black Butte diatreme, Missouri River Breaks, Montana [351].

The second model is where the crater geomorphology is dominated by largest explosion event during the eruption sequence. Thus, the crater size directly represents the 'peak' (or maximum) energy released during the largest possible shallow explosion [202, 313, 343-344, 352]. This model of crater growth (Figure 7B) for phreatomagmatic volcanoes is proposed on the basis of analogues from phreatic eruption, such as Uso craters, Hokkaido, Japan in 2000 [352], and experiments on chemical and nuclear explosions [344]. In this model, the crater diameter $(D)$ is a function of the total amount of ejected tephra $\left(\mathrm{V}_{\text {ejecta }}\right)$ [313]:

$$
\mathrm{D}=0.97 V_{\text {ejecta }}^{0.36}
$$

which can further be converted into explosion energy (E) as:

$$
\mathrm{E}=4.45 \times 10^{6} \mathrm{D}^{3.05}
$$


which approximates the largest energy released during the eruptions. This relationship between crater size and ejected volume was based on historical examples of phreatomagmatic eruptions [313]. These historical eruptions are, however, associated with usually polygenetic volcanoes, such as Taupo or Krakatau, and not with classical monogenetic volcanoes, except the Ukinrek maars, near Peulik volcano, Alaska. In this model, the largest phreatomagmatic explosion governs the final morphology of the crater, so the crater size correlates with the peak energy of the maar-forming eruption directly [343]. Scaled experiments showed that there is a correlation between the energy and the crater depth and diameter [353] if the explosions take place on the surface [344]. Most of the explosions modelled in Goto et al. [344] were single explosions, only a few cratering experiments involved multiple explosions at the same point [344], which is more realistic for monogenetic eruptions. In these multiple explosions, the crater did not grow by subsequent smaller explosions, possibly because the blast pressure was lower than the rock strength when it reached the previously formed crater rim [344]. As noted by Goto et al. [344], such experimental explosions on cratering are not applicable to underground eruptions; therefore, they do not express the energy released by deepseated eruptions generating three-phase (solid, gas and fluid) debris jets during diatreme formation [e.g. 350]. Morphologically, these deep-seated eruptions have a minor effect on crater morphology and diameter, and their deposits rarely appear within the ejecta ring around the crater.

Theoretically, both emplacement models are possible because both mechanisms can contribute significantly to the morphology of the resulting landform. The incremental growth model is based on statigraphy, eye-witnessed historical eruptions and experiments [81, 152, 198-199, 346-347], while the largest explosion model is based on analogues of chemical or nuclear explosion experiments, phreatic eruptions and impact cratering [313, 344, 353-354]. Based on eye-witnessed eruptions and geological records, the crater diameter as a morphometric signature for maar-diatreme and tuff ring volcanoes is the result of complex interplay between the eruptions and the substrate. The dominant processes, such as many, small-volume explosions with various energies migrating within the conduit system vertically and horizontally, as well as gradual mass wasting depending on the physical properties of rock strength, are what control the final crater diameter. On the other hand, the substrate beneath the volcano also plays an important role in defining crater morphology, as highlighted for terrestrial volcanic craters [209, 229, 355], as well as extraterrestrial impact craters [356]. In different substrates, different types of processes are responsible for the mass wasting. For example, an unconsolidated substrate tends to be less stable due to explosion shock waves that may liquefy water-rich sediments, and induce grain flow and slumping, enlarging the crater [229]. On the other hand, in a hard rock environment, the explosions and associated shock waves tend to fracture the country rock, depending on its strength, leading to rock falls and sliding of large chucks from the crater rim [229]. The crater walls in these two contrasting environments show different slope angles [229, 345]. These differences in the behaviour of the substrate in volcanic explosions may cause some morphological variations in the ejecta distribution and the final morphology of the crater (Figure 8). 


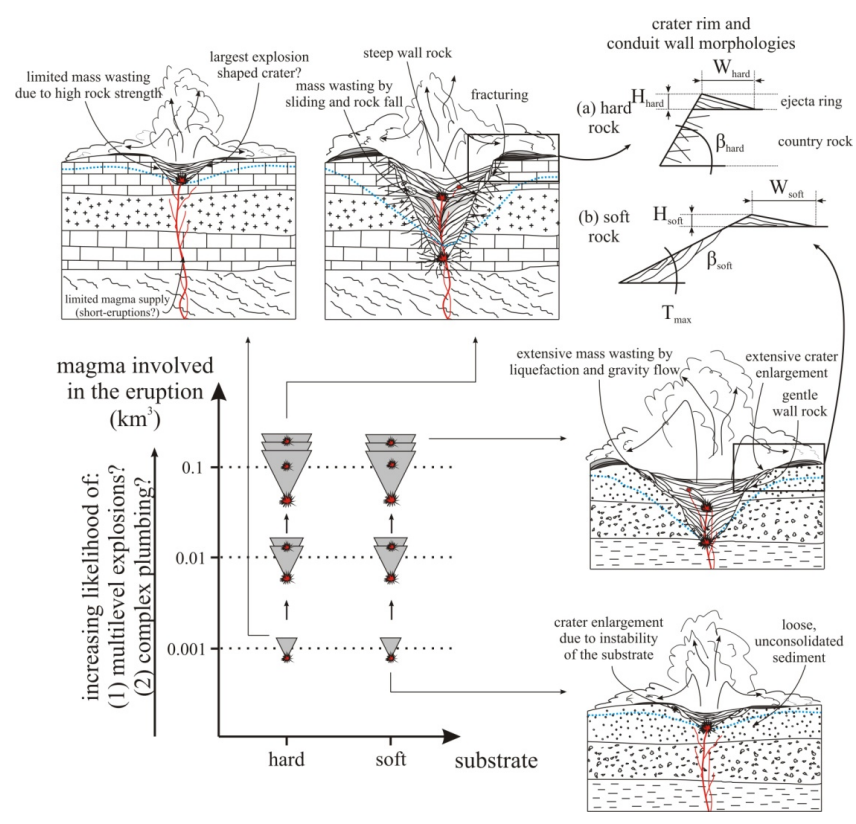

Figure 8. Morphology of volcanic crater and diatreme generated by phreatomagmatic eruptions in soft and hard substrate environments. The parameters ( $\beta$ - wall rock angle, $\mathrm{H}$ - ejecta ring height over the surrounding topography, $\mathrm{W}-$ flank width of the ejecta ring) for crater morphologies have the following possible relationships: $\beta_{\text {hard }}>\beta_{\text {softi }}$ while the $\mathrm{H}_{\text {hard }}>\mathrm{H}_{\text {soft }}\left(\right.$ ?) and $\mathrm{W}_{\text {hard }}>\mathrm{W}_{\text {soft }}($ ?)

The crater diameter is an important morphometric parameter in volcanic landform recognition; however, the final value of the crater diameter is the result of a complex series of processes, usually involving syn-eruptive, mass wasting processes of the crater walls, e.g. the 1977 formation of the Ukinrek maars in Alaska [357-358]. This makes the direct interpretation of crater diameter values more complicated than predicted by simple chemical and nuclear cratering experiments [313, 344]. Thus, the incremental growth (multiple eruptions + mass wasting) model seems to be a better explanation of the growth of a crater during phreatomagmatic eruptions [198-200, 267, 346, 359] and kimberlite volcanism [360-361]. Thus, the morphometric data of a fresh maar or tuff ring volcano contain cumulative information about the eruption energy, the location and depth of (shallow) explosion loci, as well as the stability of the country rock and associated mass wasting. The largest eruption dominated model may only be suitable to express energy relationships without the effects of mass wasting from the crater walls. This probably exists in only a few limited sites. For example, these eruptions should take place from a small-volume of magma, limiting the duration of volcanic activity and reducing the possibility of development of a diatreme underneath (Figure 8). Additionally, these eruptions should be in a consolidated hard rock environment, with high rock strength and stability. The following model for the interpretation of crater diameter and morphology data can be applied for phreatomagmatic volcanoes (Figure 8). This model integrates both conceptual models for crater and edifice growth, but 
the majority of craters experience complex development instead of the dominance of the largest explosion event. The likelihood of the largest explosion event dominated morphology is limited to simple, short-lived eruptions due to limited magma supply or vent migration in a hard rock environment (Figure 8). If the magma supply lasts, the development of a diatreme underneath starts that has a further effect on the size, geometry and morphology of the crater of the resultant volcano.

The crater diameter is often a function of basal edifice diameter $\left(\mathrm{W}_{\mathrm{co}}\right)$ or height $\left(\mathrm{H}_{\mathrm{co}}\right)$, creating ratios which are commonly used in landform recognition in extraterrestrial environments [177, 179, 340]. $W_{\text {co }}$ is often difficult to measure because of the subjectivity in boundary delimitation [293]. This high uncertainty in delimitation of the crater boundary is a result of the gradual thinning of tephra with distance from the crater, with usually a lack of a distinct break in slope between the ejecta ring's flanks and the surrounding tephra sheet, e.g. the Ukinrek maars, Alaska [357-358]. Any break in slope could also be smoothed away by post-eruptive erosional processes. The crater height estimates vary greatly for maar-diatreme and tuff ring volcanoes, but they are usually $\leq 50 \mathrm{~m}[199,223,293]$. This small elevation difference from the surrounding landscape gives rise to some accuracy issues, particularly regarding the establishment of the edifice height.

To demonstrate the limitations (e.g. input data accuracy, data type, and genetic oversimplification) of morphometric signature parameters on phreatomagmatic volcanoes, two examples (Pukaki and Crater Hill) were selected from the Quaternary Auckland volcanic field in New Zealand. Both volcanoes above were used to establish the average morphometric signature of an Earth analogue phreatomagmatic volcano [e.g. 293]. The early morphometric parameters were measured from topographic maps having coarse contour line intervals (e.g. 20-30 m), which cannot capture the details of the topography accurately. Some cross-checks were made on the basic morphometric parameters established from topographic maps and Digital Elevation Models (DEMs) derived from airborne Light Detection And Ranging (LiDAR) survey. The results showed that the differences in each parameter could be as high as $\pm 40 \%$. In addition, both the Pukaki and the Crater Hill volcanoes from Auckland were listed as "tuff rings" [293], due to the oversimplified view of monogenetic volcanism in the 1970s and 80s. Their eruption history, including volume, facies architecture and morphology, are completely different. The present crater floor of Pukaki volcano is well under the syn-eruptive surface, thus it is a maar volcano sensu stricto following Lorenz [199]. This was formed by a magma-water interaction driven phreatomagmatic eruption from a small volume of magma of $0.01 \mathrm{~km}^{3}$ estimated from a DEM and corrected to Dense Rock Equivalent (DRE) volume [362-363]. The present facies architecture of this volcano seems quite simple (e.g. like an $E_{4}$ volcano in Figure 6). On the other hand, Crater Hill has a larger eruptive volume of $0.03 \mathrm{~km}^{3}$ [362-363] and experienced multiple stages of phreatomagmatism (at least 3) and multiple stages of magmatic eruptions (at least 5) with many transitional layers between them, forming an initial tuff ring and an intra-crater scoria cone [80]. Later eruption formed an additional scoria cone and associated lava flow that filled the crater with lava up to $120 \mathrm{~m}$ in thickness $[80,364]$. Consequently, Crater Hill is an architecturally complex volcano with complex eruption history, i.e. at least an $\mathrm{E}_{4226}$. The important implication of the examples 
above and the usual complex pattern and processed involved on the establishment of the final geomorphology (e.g. incremental crater growth) are that morphometric signature (if it exists) can be only used for phreatomagmatic volcanoes if the eruption history of the volcano is reconstructed. In other words, parameters to express morphometric signature cannot be compared between volcanoes with different eruption histories (i.e. they are characterized by different phases with different eruption styles). Comparison without knowledge of the detailed eruption history could be misleading. Furthermore, the morphometric signature properties used in extraterrestrial volcano recognition for crater-type volcanoes should be reviewed, using a volcanological constraint on the reference volcano selection.

\subsubsection{Cone-type monogenetic volcanoes}

Cone-type monogenetic volcanoes, such as spatter- (Figure 2), scoria (or cinder; Figure 3) and tuff cones (Figure 5), are typically built up by proximal accumulation of tephra from low to medium (0.1-10 km in height) eruption columns and associated turbulent jets, as well as block/bombs that follow ballistic trajectories [188, 223, 288, 365-367]. Deposition from localized pyroclastic density currents is possible, mostly in the case of tuff cones [223, 265, 283] and rarely in the case of scoria cones from violent Strombolian eruptions [188]. The primary morphology of cone-type monogenetic volcanoes could be expressed by various morphometric parameters, including height $\left(\mathrm{H}_{\mathrm{co}}\right)$, basal $\left(\mathrm{W}_{\mathrm{co}}\right)$ and crater diameter $\left(\mathrm{W}_{\mathrm{cr}}\right)$ and their ratios $\left(\mathrm{H}_{\mathrm{co}} / \mathrm{W}_{\mathrm{co}}\right.$ or $\left.\mathrm{W}_{\mathrm{cr}} / \mathrm{W}_{\mathrm{co}}\right)$, inner and outer slope angle or elongation. On a fresh edifice, where no post-eruptive surface modification has taken place, these morphometric parameters are related to the primary attributes of eruption dynamics and syn-eruptive sedimentary processes. However, there are potentially two valid models to explain their dominant construction mechanisms, including a ballistic emplacement with drag forces and fallout from turbulent, momentum-driven jets at the gas-thrust region [84, 182, 185, 368-369]. In both models, the angle of repose requires loose, dry media. This criterion is rarely fulfilled in the case of a tuff cone [e.g. 223, 234] and littoral cones that form during explosive interactions between lava and water [e.g. 203, 204]. In these cases the ejected fragments have high water-contents that block the free avalanching of particles upon landing [223, 252, 259, 283, 286]. This is inconsistent with other magmatic cone-type volcanoes; the growth processes of tuff and littoral cones are not discussed in further detail here.

The ballistics model with and without drag for scoria cone growth was proposed as a result of eye-witness accounts of eruptions of the NE crater at Mt. Etna in Sicily, Italy [185]. This model is based on the assumption that the majority of the ejecta of a volcanic cone is coarse lapilli and block/bombs ( $\geq 8-10 \mathrm{~cm}$ in diameter), thus they follow a (near) ballistic trajectory after exiting the vent (Figure 9A). Consequently, the particle transport is momentum-driven, as documented for the bomb/block fraction during bursting of large bubbles in the upper conduit during Strombolian style explosive eruptions [180, 183, 370]. The particle velocity of such bomb/blocks was up to $70-80 \mathrm{~m} / \mathrm{s}$ for a sensu stricto Strombolian style eruption measured from photoballistic data [371-372]. However, recent studies found that the typical exit velocities are about 100-120 m/s [180, 183] and they could reach as high as $400 \mathrm{~m} / \mathrm{s}$ [373]. These studies also showed that the typical particle diameter is $\mathrm{cm}$-scale or less instead of 
dm-scale [180, 183], which cannot be derived purely from impact breakage of clasts upon landing [182, 368]. Especially during paroxysmal activity at Stromboli [374] or more energetic violent Strombolian activity [83, 163], the dominance of fine particles in the depositional records contradicts the ballistics emplacement model for the cones.

To solve the debate about cone growth, the jet fallout model was proposed [182], based on the fact that there is a considerably high proportion of fines in cone-building pyroclastic deposits $[60,182,288]$. This proposed behaviour is similar to the proximal sedimentation from convective plumes, forming cones with similar geometry to scoria cones, e.g. the 1886 eruption of Tarawera, Taupo Volcanic Zone, New Zealand [375] or the 1986 eruption of Izu-Oshima volcano, Japan [368]. The fines content does not fulfil the criteria of pure ballistic trajectory, thus turbulent, momentum-driven eruption jets (Figure 9A) should be part of the cone growth mechanisms $[182,368,376]$. As documented above, scoria cones demonstrate a wider range of granulometric characteristics [182] than previously thought [185]. These slight or abrupt changes of grain size within an edifice imply that the term "scoria cone" is not as narrow and well-defined as proposed in earlier studies [71, 185, 189, 301]. Consequently, there should be a spectrum of characteristics within the "scoria cones" indicating the existence of spatter-, lapilli- and ash-dominated varieties [68, 288]. Such switching from classical lapilli-dominated to ash- or block-dominated cone architectures reflects syn-eruptive reorganization of conduit-scale processes, including

1. multiple particle recycling and re-fragmentation during conduit cleaning [180, 377] or

2. changes in magma ascent velocity (i.e. increase or decrease in the efficiency of gas segregation) that in turn effect the viscosity of the magma [150, 163, 378].

The latter case may or may not cause a change in eruption style (e.g. a shift from normal Strombolian-style to violent Strombolian-style eruption) that could effectively lead to changes in the grain size distribution of the ejecta by possible skewing towards finer fractions $(\leq 1-2 \mathrm{~cm})$. This switching has significant consequences on pyroclast transport as well. The higher efficiency of magma fragmentation and production of finer pyroclasts (e.g. ash) causes more effective pyroclast-to-gas heat transfer in the gas-thrust region. A buoyant eruption column is created when the time of heat transfer is shorter than the residence time of fragments in the lowermost gas-thrust region [111, 182, 379]. Thus, particle transport shifts from momentum- to buoyancy-driven modes [182-183]. Based on numerical simulations, these changes in the way pyroclasts are transported are consistent with modelled sedimentation trends from jet fallout as a function of vent distance [182]. Once the eruption has produced medium (Md $\phi \leq 10-20 \mathrm{~mm}$ ) and coarse fragments (Md $\phi \leq 50-100 \mathrm{~mm}$ ), pyroclasts show an exponential decrease in sedimentation rates away from the vent [182]. This is in agreement with the trend predicted by the ballistic emplacement model [185]. However, once the overall fragment size is dominated by fines $(\mathrm{Md} \phi \leq 2-3 \mathrm{~mm})$, the maximum sedimentation rate departs further towards the crater rim [182]. The threshold particle launching velocity is about $\geq 50 \mathrm{~m} / \mathrm{s}$ [182]. The fragment diameter of $\mathrm{Md} \phi \leq 2-3 \mathrm{~mm}$ is consistent with the calculated threshold for formation of buoyant, eruptive columns during violent Strom- 
bolian activity [111], but is significantly finer than fragments ( $\mathrm{Md} \phi \leq 10-12 \mathrm{~mm}$ ) generated during some paroxysmal events recorded at Stromboli in Italy [374].

In the case of scoria cone growth the final morphology is not only dependent on the mode of pyroclast transportation via air, but also on significant post-emplacement redeposition. If particles are sufficiently molten and hot, their post-emplacement sedimentation processes usually involve some degree of welding/agglutination and rootless lava flows may form [171-172]. In this case, high irregularity in the flank morphology is expected due to the variously coalescent large lava clots and spatter [171-172, 380]. If the particles are brittle and cool, as well as having enough kinetic energy to keep moving, they tend to avalanche on the inclined syn-eruptive depositional surface [84, 141, 172, 185, 234, 288]. The avalanching grain flows often give rise to inversely-graded horizons or segregated lenses within the overall homogenous, clast-supported successions of the accumulating pyroclast pile, while the hot particles cause spatter-horizons in the statigraphy (Figure 10). In the earlier case, the criterion to sustain efficient grain flow processes on the initial flank of a pyroclastic construct is that the particles have to be granular media (i.e. loose and sufficiently chilled). The properties such as grain size, shape and surface roughness determine the angle of repose, which is a material constant [381]. These are all together responsible for the formation of usually smooth cone flank morphologies.

Classically, scoria cones are referred to as being formed by Strombolian-style eruptions, in spite of the fact that Stromboli volcano, Aeolian Islands, is not a scoria cone. In reality, scoria cones are formed by "scoria cone-forming" eruptions. Thus, the term scoria cone includes every sort of small-volume volcano with a conical shape and basaltic to andesitic composition. Additionally, during scoria cone growth, three major styles of internally-driven eruption types can be distinguished, Hawaiian, Strombolian and violent Strombolian, and an additional externally-driven eruption style, such as phreatomagmatism-dominated, is also expected (e.g. Figure 6). From the eruption styles listed above, at least the first three could individually form a "scoria cone", or similar looking volcano, which is rarely or never taken into account during interpretation of geomorphic data of a monogenetic volcano. The cone growth mechanism is, here, considered to be a complex interplay between many contrasting modes of sedimentation of primary pyroclastic materials, including transport via air (by turbulent jets and as ballistics) and subsequent redistribution by particle avalanching (Figure 9A). It is also important to note that cone growth is not only a constructive process; there could also be destructive phases. These processes (e.g. flank failure or crater breaching) alter the morphology in a short period of time. Consequently, the edifice growth is not a straightforward process (e.g. a simple piling up of pyroclastic fragments close to the vent), but rather a combination of constructive and destructive phases at various scales. The spatial and temporal contexts of such constructive and destructive processes are important factors from a morphometric stand point. In this chapter, two modes of cone growth mechanisms are recognized (Figures 9B and C) cones formed by:

1. a distinct and stable eruption style (e.g. $\mathrm{E}_{\text {simple }}$ ) and by

2. various magma eruption styles with transitions between them (e.g. $\mathrm{E}_{\text {compound }}$ or $\mathrm{E}_{\text {complex }}$ ), during the eruption histories. 
The simple cone growth model is applicable to cone growth from a single and stable eruption style, e.g. Strombolian, Hawaiian or violent Strombolian styles only (Figure 9B). Theoretically, if an edifice is formed by a repetition of one of these well-defined and stable eruption style without fluctuation of in efficiency or any changes, the crater excavation and diameter, as well as the mode of pyroclast transport, should vary in a narrow range, i.e. fragmentation mechanism 'constant' (Figure 9B). The first explosions when the gas bubbles manage to escape from the magma leading to the explosive fragmentation of the melt, usually take place on the pre-eruptive surface or at a few tens of meters deep [57, 84, 185, 382-383]. After the first eruption, there is a time involved to either excavate the crater or pile up ejecta around the vent, which is in turn dependent on the eruption style and the tephra accumulation rate. Once the threshold crater rim height is reached, the height and its position are attached to properties of certain eruption dynamics (Figure 9B). In other words, the eruption style and related pyroclast transport distribute tephra to limited vertical and horizontal directions. Due to the steadiness of eruption style, particle fallout from the near-vent, dilute jets at the gas-thrust region and ballistics have an 'average' vertical distance that they travel. This 'average' will determine the width and relative offset of the crater rim above the crater floor, which grows rapidly during the initial establishment of the crater morphology (first cartoon in Figure 9B) and then slows down (second and third cartoons in Figure 9B). Of course the location, morphology of the crater rim and floor are not just dependent on the efficiency of the magma fragmentation, but the subsequent wall rock failure, as documented by Gutmann [369], similar to the development of maar-diatreme volcanoes (Figure 7). Due to the stability of the conduit and a single eruption style, the role of such failures in the control of morphology is minimal in comparison with complex modes of edifice growth (see later).

This growth model is applicable to simple eruptions, with steady eruption styles and possibly steady magma discharge rates, such as the violent-Strombolian eruptions during the Great Tolbachik fissure eruptions in Kamchatka, Russia [84, 382] or the Strombolian-style eruption during the growth of the NE crater at Mt. Etna [185]. During the Tolbachik fissure eruptions, the rim-to-rim crater diameter of Cone 1 grew rapidly from $56 \mathrm{~m}$ to $127 \mathrm{~m}$ during the first 5 days, and later slowed and stayed in a narrow range around $230-280 \mathrm{~m}$ during the rest of the eruptions [84, 382-385]. This is similar to certain stages of growth of the NE crater at Mt. Etna $[84,185]$. This means the crater widens initially until a threshold width is reached, which corresponds to the maximum strength of the pyroclastic pile and the limits of the eruption style (Figure 9B). This trend seems to be consistent with an exponential growth of crater width over time until the occurrence of lava flows, as documented at Cone 1 and 2 of the Tolbachik fissure eruptions [e.g. 383]. The maximum range of the crater width appeared to be reached once the lava outflowed from the foot of the cones. This can be interpreted as an actual decrease in magma flux fuelling the explosion, and therefore the pyroclast supply for flank growth. Assuming that the magma is torn apart into small particles and are launched with sufficiently high initial velocity to the air, e.g. Strombolian eruptions, the particles have enough time to cool down, thus upon landing they initiate avalanching due to their kinetic energy. These processes will smooth the syn-eruptive surface to the angle of repose of the ejected pyroclasts if the pyroclastsupply is high enough to cover the entire flank of the growing edifice. If the angle of repose of the tephra, $\theta$, depending on granulometric characteristics, and the height of the crater rim, $H$, are known at every stage of the eruption $(i=1,2, \ldots, n)$, the flank width $\left(W_{i}\right)$ would indicate at a certain stage of growth (Figure 9B): 


\section{(A) initialization of the volcanism}

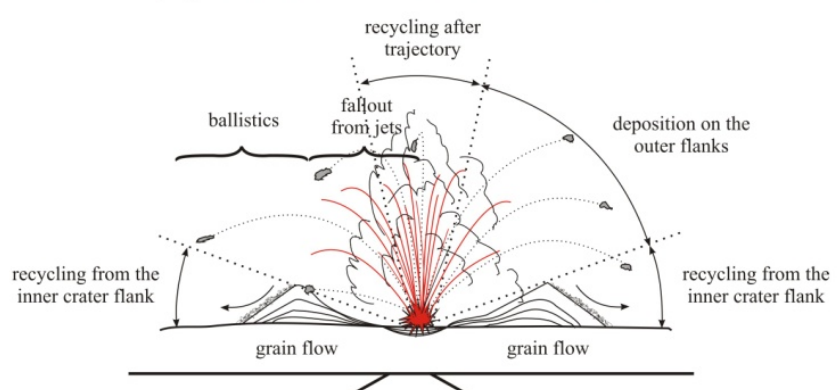

(B) simple cone growth
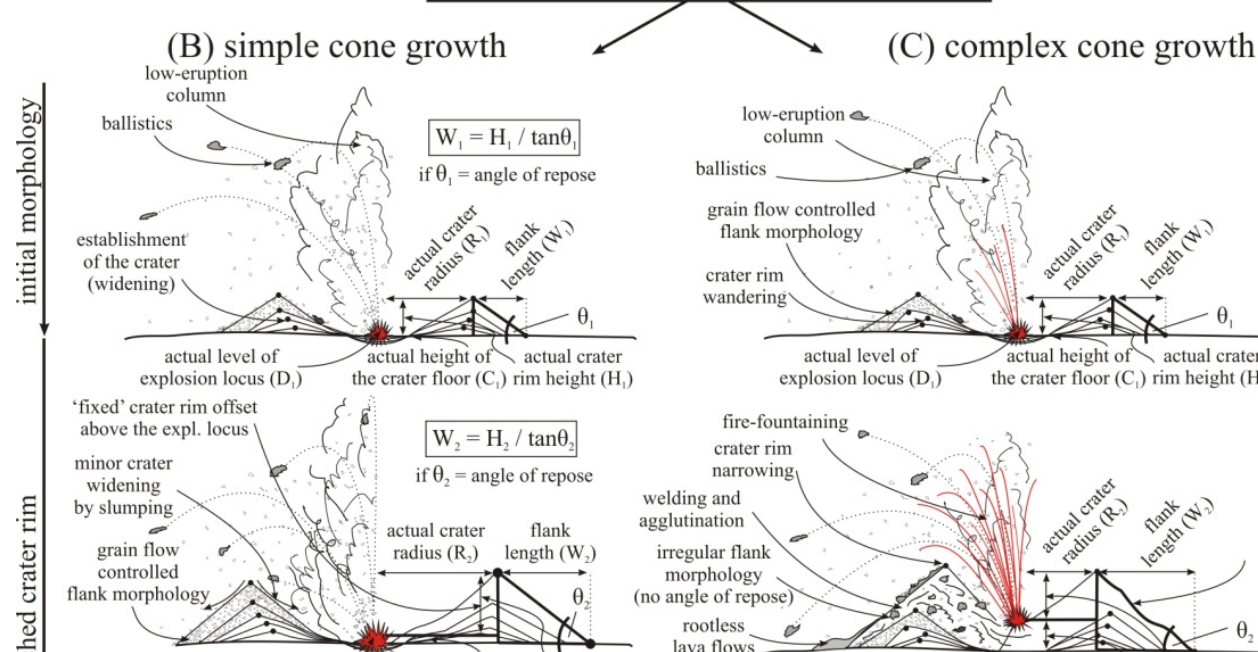

actual level of actual height of actual crater explosion locus $\left(\mathrm{D}_{2}\right) \quad$ the crater floor $\left(\mathrm{C}_{2}\right)$ rim height $\left(\mathrm{H}_{2}\right)$
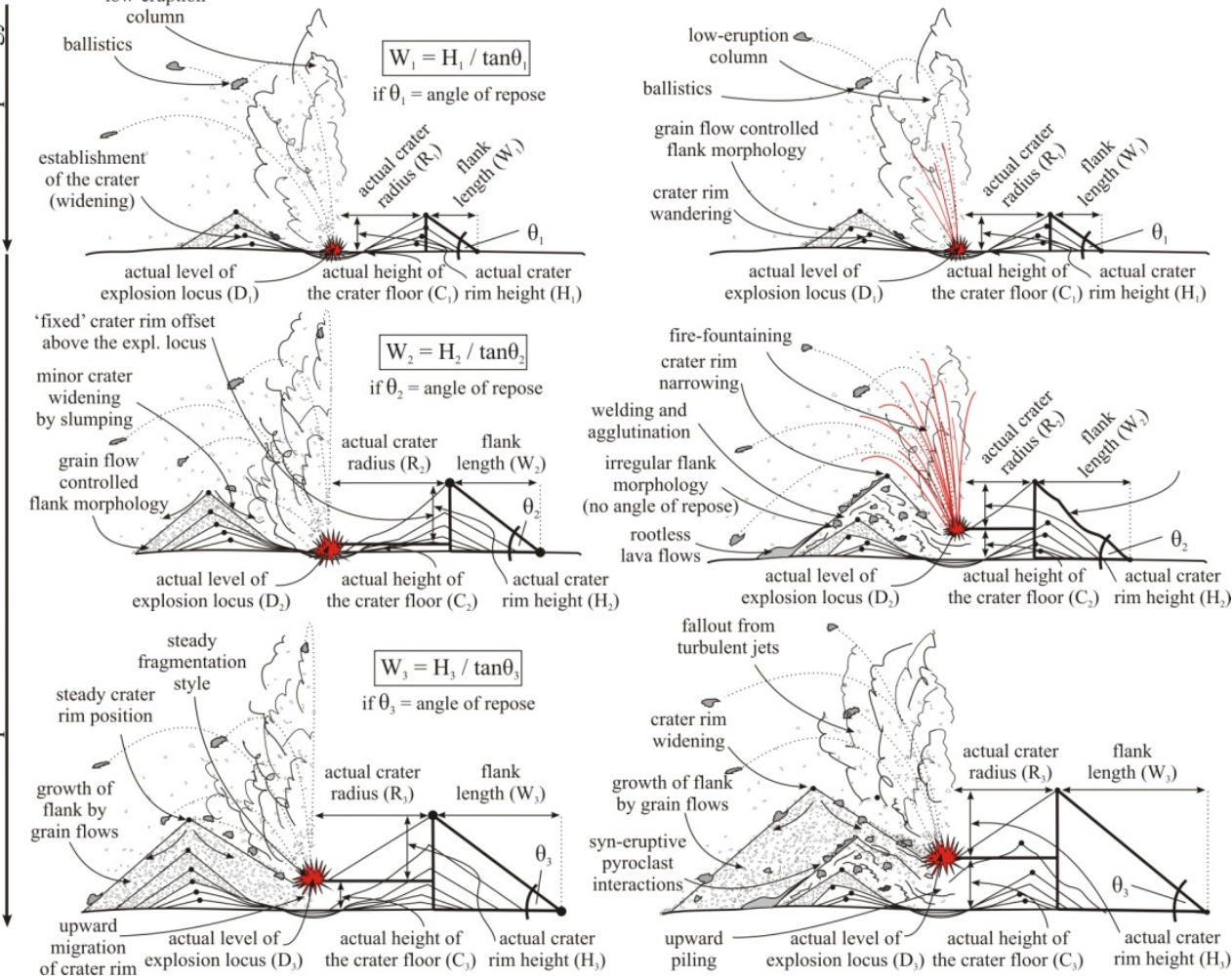

Figure 9. Growth of cone-type volcanoes (e.g. scoria cones) through ballistics' emplacement and jet fallout models. After the initialization of the volcanism (A), there are two different types of cone growth: simple and complex. The simple cone growth model (B) supposes a steady fragmentation mechanism and associated eruptive style and sedimentary processes, thus the angle of repose is near constant, $\theta_{1}=\theta_{2}=\theta_{3}$ over the eruption history. The variation of the relative height of the crater $\operatorname{rim}(\mathrm{H})$ above the location of the explosion locus and the radius of the crater ( $R$ ) is 'fixed' or varies in a narrow range $\left(\mathrm{H}_{1} \leq \mathrm{H}_{2}=\mathrm{H}_{3}\right.$ and $\left.\mathrm{R}_{1} \leq \mathrm{R}_{2}=\mathrm{R}_{3}\right)$, after the initial rapid growth of rim height and crater width. The simple cone growth model implies that constructional and flank morphologies are the results of a major pyroclasttransport mechanism (e.g. grain flows in the case of a scoria cone or welding, formation of rootless lava flows in the 
case of spatter cones). On the other hand, the complex cone growth model (C) involves gradual or abrupt changes in eruption style, triggering multiple modes of pyroclast transport, and possible changes in the relative height and diameters of the crater $\operatorname{rim}\left(\mathrm{H}_{1} \neq \mathrm{H}_{2} \neq \mathrm{H}_{3}\right)$. The granulometric diversity allows for post-emplacement pyroclast interactions which permits or blocks the free-avalanching of the particle on the outer flanks. Therefore, the angle of repose is constant and may not always be reached $\left(\theta_{1} \neq \theta_{2} \neq \theta_{3}\right)$, especially when clast accumulation rate and temperature is higher, causing welded and agglutinated spatter horizons.

$$
\mathrm{W}_{\mathrm{i}}=\mathrm{H}_{\mathrm{i}} / \tan \theta_{\mathrm{i}}
$$

When the eruption style is constant during the eruption and produces pyroclasts of the same characteristics, the pyroclasts behave as granular media (i.e. they are controlled by the angle of repose); the aspect ratio between the height and flank width should be in a narrow range until the 'tandem' relationship is established between the crater rim and explosion loci. Once the eruption is in progress, the explosion locus stay either at the same depth (e.g. at the pre-eruptive ground level) or migrates upwards if enough material is piled up within the crater resulting in a relative up-migration of the crater floor over time (Figure 9B). Consequently, this upward migration of the explosion locus should result in an elevation increase of the crater rim, if the eruption style remains the same. Once the crater rim rises, the majority of the pyroclasts avalanche downward from higher position, which creates a wider flank and increases the overall basal width of the edifice. The repetition of such crater rim growth and flank formation takes place until the magma supply is exhausted. Due to the dominance of loose and brittle scoria in the edifice, the $\mathrm{H}_{\mathrm{co}} / \mathrm{W}_{\text {co }}$ ratio is in a narrow range in accordance with Eq. 3. Although, there is a slight difference between $\mathrm{H}_{\text {co }} / \mathrm{W}_{\text {co }}$ and $\mathrm{H}_{\mathrm{i}} / \mathrm{W}_{\mathrm{i}}$, because the former contains the crater. The crater is possibly the most sensitive volcanic feature of a cone that could be modified easily (e.g. shifting in eruption style in the course of the eruptions and/or vent migration). Finally, this growing process is in agreement with the earlier documented narrow ranges of the $\mathrm{H}_{\mathrm{co}} / \mathrm{W}_{\mathrm{co}}$ ratio that are governed by the angle of repose of the ejecta $[84,301]$.

The complex cone growth model assumes the cone is the result of many distinctive eruption styles and changes between them, which trigger a complex cone growth mechanism from various eruptive and sedimentary processes (Figure 9C). Such changes usually relate to changes from one eruption style to another, which have consequences for the morphological evolution of the growing cone. The switching in efficiency of magma fragmentation can be triggered by the relative influence of externally and internally-governed processes or reorganization of internal or external controls without shifting from one to the other. An example for the first change is a gradual alteration in the abundance of ground water and consequent shift from phreatomagmatism to magmatic eruption styles. On the other hand, the reorganization of processes in either in the internally- or externally-driven eruption styles could be related to the changes in degree of vesiculation and efficiency of gas segregation in the conduit system. Each of these changes could modify the dominant eruption style that determines the grain size, pyroclast transport and in turn edifice growth processes. An internal gas-driven magma fragmentation leading to a Hawaiian eruption produces larger (up to a few meters) magma clots that are emplaced ballistically, while fines are deposited from turbulent jets and a low-eruption column, in agreement with the processes observed at 
Kilauea Iki in Hawaii [e.g. 176]. In this eruption style, the dominance of coarse particles (e.g. lava clots up to 1-2 $\mathrm{m}$ in diameter) are common. These large lava clots cannot solidify during their ballistic transport, and therefore after landing they could deform plastically, weld and/or agglutinate together or with other smaller pyroclasts [171, 380], depending on the accumulation rate and the clast temperature [172]. As a result of the efficient welding processes, the landing is not usually followed by free-avalanching, unlike loose, sufficiently cooled, brittle particles from other eruption styles, e.g. normal Strombolian styles. At the other end of the spectrum, energetic eruptions styles, such as violent Strombolian or phreatomagmatic eruptions, tend to generate localized sedimentation from pyroclastic density currents such as base surges. Similar to spatter generation, pyroclasts from pyroclastic density currents do not conform to the angle of repose. In contrast, the pyroclasts from sensu stricto Strombolian-eruptions are sufficiently fragmented to suffer rapid cooling during transport either as ballistics or fallout from turbulent jets and eruption columns (Figure 9C). Thus, the particle with sufficient kinetic energy post-emplacement can fuel grain avalanches on the outer flanks of a growing pyroclastic pile. The active grain flows deposit pyroclasts on flanks in accordance with the syn-eruptive depositional surface properties and granulometric characteristics that provide the kinetic and static angle of repose of the granular pile. This is sustained until the ejected material is characterized by the same granulometric characteristics. With increasing degree of magma fragmentation, the dominant grain size of the tephra decreases. The increased efficiency of the magma fragmentation (e.g. violent Strombolian eruptions) commonly results in a higher eruption column, and therefore broader dispersion of tephra. The high variability and fluctuating eruption styles form a wide range of textural varieties of edifice such as Lathrop Wells in Southwest Nevada Volcanic Field, Nevada [60, 188], Pelagatos in Sierra Chichinautzin, Mexico [14, 378] or Los Morados, Payún Matru, Argentina [273]. Due to the variability in eruption styles, particles have different surfaces or granulometric characteristics. These differences induce some fine-scale post-emplacement pyroclast interactions. The effect of these syn-eruptive pyroclast interactions could prevent effective grain flow processes, 'reset' or delay (previous) sedimentary processes on the flanks of a growing conical volcano. Thus it could be a key control to determine the flank morphology of the resultant volcanic edifice. Examples for syn-eruptive granulometric differences can be found in the pyroclastic succession of the Holocene Rangitoto scoria cone in Auckland, New Zealand (Figure 10). During deposition of beds with contrasting dominant particle sizes, the angle of repose is not always a function of granulometric properties, but can be a result of the mode of pyroclast interactions with the syn-eruptive depositional surface. There is wide range of combinations of pyroclast interactions among ash, lapilli, block and spatter (Figure 10). Such transitions in eruption style and resulting pyroclast characteristics are important due to their blocking of freshly landed granular particles conforming (immediately) to the angle of repose expected if they were circular, dry and hard grains. For instance, the deposition of an ash horizon on a lapilli-dominated syn-eruptive surface must fill the inter-particle void, causing ash 'intrusions' into the lapilli media (Figure 10). These pyroclast interactions possibly slow the important cone growing mechanisms (e.g. grain flow efficiency) down, creating a sedimentary delay when the angle of repose is established on the syn-eruptive surface. In the complex cone growth model, the changes of eruptions 
style have an effect on the relative position of the crater rim shifting the position of the maximum sedimentation and the mode of pyroclast transport [182]. For example, switching from normal Strombolian to violent Strombolian style eruptions could increase the initial exit velocity from the usual $60-80 \mathrm{~m} / \mathrm{s}[180,183,372,386]$ to higher values, $\geq 150-200 \mathrm{~m} / \mathrm{s}[111,382$, 387-388]. This shift in eruption style causes further decrease in the grain size of the ejecta $[163,367,389]$. This change could altogether cause migration of the location of the maximum sedimentation point further towards the crater rim if the tephra is transported by jet instead of pure ballistic trajectories [182]. Such changes in eruption styles introduce significant horizontal and vertical crater rim wandering during the eruption history of a monogenetic volcano (Figure 9C). This wandering modifies, in turn, the sedimentary environment leading the formation of cones with complex inner facies architectures, which may or may not be reflected by the morphology. Consequently, the major control in this cone growth model is on the eruption styles and their fluctuations over the eruption history.

In both cone growth models, lava flows can occur as a passive by-product of the explosive eruptions 'draining' the degassed magma away from the vent. Once the magma reaches the crater without major fragmentation it can either form lava lakes and/or (later) intrude into the flanks, increasing the stress [111, 298, 369]. When the magma pressure exceeds the strength of the crater walls, the crater wall may collapse or be rafted outwards [111, 369]. Sometimes, the magma flows out from foot of the cone, possibly fed from dykes [188, 273, $367,369,388,390-391]$. In this case the flank collapse is initiated by the inflation of the lava flow by discrete pulsation of magma injected beneath the cooler dyke margins [392-393] beneath a certain flank sector of a cone [111]. If the lava yield strength is reached and overtakes the pressure generated by the total weight of a certain flanks sector, flank collapse and subsequent rafting of remnants are common [111, 273, 390], leading to complex morphologies with breached craters and overall horse-shoe shape [322, 394]. The direction of crater breaching of scoria cones may not always be the consequence of effusion activity, but may coincide with regional/local principal stress orientations or fault directions [298, 315, 395-396]. If the magma supply is sufficient, the edifice that has been (partially) truncated by slope failure could be (partially) rebuilt or 'reheal' as documented from Los Morados scoria cone in Payun Matru, Argentina [273] or Red Mountain, San Francisco Volcanic Field, Arizona [397]. The direction of lava outflow from a cone commonly overlaps with the overall direction of background syn-eruptive surface inclination. This overall terrain tilt could cause differences in the tension in the downhill flank sector [82, 298, 391, 398]. Any kinds of changes during basaltic monogenetic eruptions could cause sudden decompression of the conduit system, leading to a change in the eruption style [273, 399]. Consequently, these destructive processes are more likely to occur during complex edifice growth, instead of simple cone growth. These changes could account for the fine-scale morphometric variability and architectural diversity observed in granular pile experiments and field observations [68, 182, 298, 314, 398]. Evidence of fine-scale morphometric variability due to lava outflow and crater breaching is observed through systematic morphometric analysis on young ( $\leq 4 \mathrm{ka}$ ) scoria cones in Tenerife [398]. Two types of morphometric variability were found: intra-cone and inter-cone variability. Intra-cone variability was characterised among individual flank facets. The slope angle variability was calculated to be as high as $12^{\circ}$ between flanks sectors along $\left( \pm 45^{\circ}\right)$ and 
perpendicular $\left( \pm 45^{\circ}\right)$ to the main axis of the tilt direction of the syn-eruptive terrain [398]. This is about a third of the entire range of the natural spectrum of angles of repose of loose, granular material, i.e. scoria-dominated flanks [84, 182]. Inter-cone variability was detected on cones of the same age. According to Wood [71], these fresh cones should be in a narrow morphometric range (e.g. slope angle of $30.8 \pm 3.9^{\circ}$ ) based on fresh and pristine scoria cones analysed from the San Francisco Volcanic Field, Arizona [71, 324]. In contrast to this expected high value, the average slope angles of the studied cones from Tenerife turned out to vary from $22^{\circ}$ to $30^{\circ}$, which has significant impact on many traditionally used interpretations of morphometric data including morphometric-based dating [e.g. 338], the morphometric signature concepts and erosion rate calculations. Both inter- and intra-cone variability were interpreted as a sign of differences in syn-eruptive processes coupled between internal, such as changes in efficiency of fragmentation, magma flux, effusive activity and associated crater breaching [398], and external controlling factors, such as interaction between pre-existing topography and the eruption processes [398]. All of these diverse eruptive and sedimentary processes are somehow integrated into the fresh morphology that is the subject of morphometric parameterization. A few of these processes could be detected while others could not, using morphometric parameters at one or multiple scales. For instance, some of this morphometric variability is usually undetectable using topographic maps and manual geomorphic analysis. This narrow variability, possibly associated with syn-eruptive differences in cone growth rates and trends, is in some instances in the range of the accuracy of the morphometric parameterization technique. For example, a manual calculation of slope angle from a 1:50 000 topographic maps with contour intervals of $20 \mathrm{~m}$ is $\pm 5^{\circ}$ [e.g. 312]. The fine-scale morphometric variability cannot be assessed accurately with this high analytical error range. On a DEM (either contour-based or airborne-based) with high vertical and horizontal accuracies (e.g. Root Mean Square Error under a few meters), this small-scale variability can be detected [e.g. 398]. An important consequence of this variability is that the initial geometry of the cone-type volcanoes, such as scoria cones, is not in a narrow range as previously expected [e.g. 71]. In other words, the morphometric signature of cone-type volcanoes are wider than described before, limiting the possibility of morphometric comparisons of individual edifices (especially eroded edifices) due to the lack of control on their initial geometries. It seems on the basis of the presented eruptive diversity, comparative morphologic studies should be focused on comparing cones that have similar processes involved in their formation (i.e. $\mathrm{E}_{\text {simple }}, \mathrm{E}_{\text {compound }}$ or $\mathrm{E}_{\text {complex }}$ ) and limited post-eruptive surface modifications (i.e. younger than a few ka in age). The morphology of a fresh ( $\leq$ a few ka) cone-type volcano is the result of primary eruptive processes; therefore, the morphometric parameters should be interpreted as the numerical integration of such eruptive diversity and mode of edifice growth. As stated by Wood [84], only fresh cones must be used for detecting causes and consequences of changes in morphology. When cone-type volcanoes from a larger age spectrum, e.g. up to a few Ma [e.g. 312, 337], are studied, the primary, volcanic morphometric signatures are modified by post-eruptive processes. Thus, they contain a mixture of syn- and post-eruptive morphometric signatures. Hence, interpretation of large morphometric datasets should be handled with care. Furthermore, it is also evident that not all geomorphic changes experienced by the edifice during the eruption history are preserved 
in the final volcano morphology. This could be due to, for instance, rehealing of the edifice after a collapse event, or changing eruption style, reflecting the complex nature of cone growth. Future research should focus on finding the link between the eruptive processes and morphology, as well as finding out how syn-eruptive constructive and destructive processes can be discriminated from each other on an 'unmodified', fresh cone.

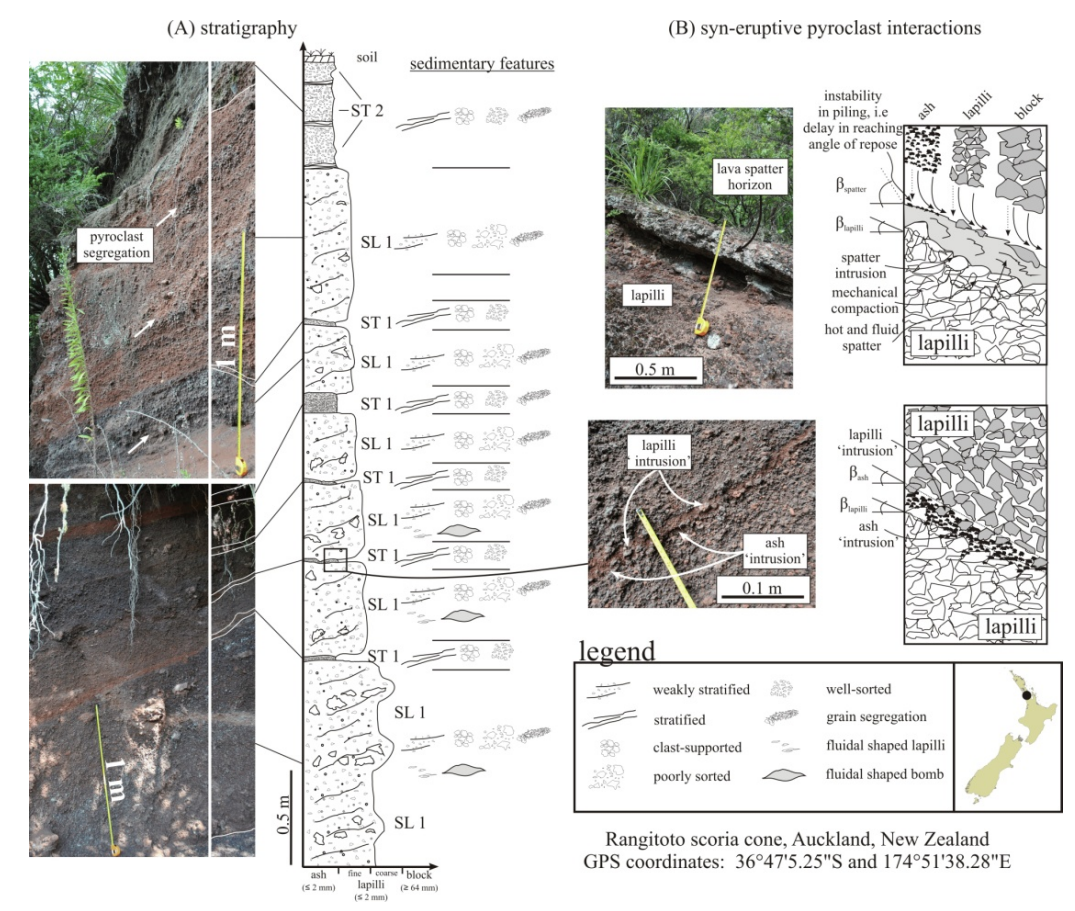

Figure 10. Stratigraphic log (A) of Rangitoto scoria cone, Auckland Volcanic Field, New Zealand showing the typical alteration of scoriaceous lapilli (SL1) and scoriaceous ash (ST1-2). Some examples are for syn-eruptive pyroclast interactions during growth of cone-type volcanoes such as scoria cones (B).

\section{Degradation of monogenetic volcanoes}

Once the eruption ceases, a bare volcanic surface is created with all of the primary morphologic attributes that have been determined by the temporal and spatial organization of the internally- and externally-controlled eruptive and sedimentary processes during the eruption history (Figure 6). The fresh surface is usually 'unstabilized' and highly permeable due to the unconsolidated pyroclasts, but there is often some degree of welding/agglutination, the presence of compacted ash, or lava flow cover. The degradation processes of a volcanic landform have a significant effect on the alteration of primary, volcanic geomorphic attributes (e.g. lowering of $\mathrm{H}_{\mathrm{co}} / \mathrm{W}_{\mathrm{co}}$ or slope angle values). The significant transition 
from primary (pristine) volcanic to erosion landforms fundamentally starts when, for example, soil is formed, vegetation succession is developed or the surface is dissected over the primary eruptive products. However, modification of the pristine, eruption-controlled morphology could happen by non-erosion processes. For example, rapid, post-eruptive subsidence of the crater of a phreatomagmatic volcano due to diagenetic compaction, or lithification of the underlying diatreme infill during and immediately after the eruptions [400-401]. This usually leads to deepening of the crater or thickening of the sediments accumulated within the crater. Some compaction and post-eruptive surface fracturing, due to the gradual cooling down of the conduit and fissure system, is also expected at cone-type volcanoes, such as after the formation of Laghetto scoria cones at Mt. Etna, Italy [184] or Pu'u 'O'o spatter/scoria cone in Hawaii [173]. These processes could cause some geomorphic modification that may affect the morphometric parameters. On the other hand, the long-term surface modification of a monogenetic volcanic landform is related to degradation and aggradation processes over the erosion history. The structure of the degradation processes that operate on volcanic surfaces can be classified into two groups based on their frequency of occurrence and efficiency:

1. long-term (ka to Ma), slow mass movements, called 'normal degradation', as well as

2. short-term (hours to days), rapid mass movements, called 'event degradation'.

In the following section a few common degradation and aggradation processes are discussed briefly.

\subsection{Long-term, normal degradation of monogenetic volcanoes}

Normal degradation is a long-term (ka to Ma) mass wasting process that occurs by a combination of various sediment transport mechanisms and erosion processes such as rill and gully erosion, raindrop splash erosion, abrasion or deflation. Normal degradation requires initiation of the erosion agent that is usually the 'product' of the actual balance between many internal and external degradation controls at various levels, such as the climate or inner architecture (Figure 11). The external environment (e.g. annual precipitation, temperature or dominant wind direction etc.) is recognized as a major control on degradation [68, $71,324-325,337-338]$, influencing the chemical weathering and rates of $\mathrm{CO}_{2}$ consumption [e.g. 402]. However, there is no single control on chemical weathering rates; the actual weathering rates are often a function of many controlling conditions [e.g. 403]. Important controls on weathering rate could be the climatic settings (e.g. surface runoff, moisture availability, temperature, atmospheric $\mathrm{CO}_{2}$ level, rates of evaporation [e.g. 404]), the tectonics (e.g. the post-orogenic increase in chemical weathering that decreases the atmospheric $\mathrm{CO}_{2}$ concentration [e.g. 405]), the geomorphology (e.g. age of the surface, surface drainage system, rates of sediment transport, relief, soil cover, sediment composition [e.g. 406]) or the biology (e.g. microorganism, plant cover, animal activity [e.g. 407]).

A combination of the abovementioned controls and processes on chemical weathering interacts in many ways depending on the internal composition and characteristics of the volcanics exposed to the environment (Figure 11). The importance of internal controls on degradation seems to be neglected by earlier studies on monogenetic volcanic edifices [e.g. 
71] in contrast with recent studies [e.g. 68]. The facies architecture and granulometric characteristics of a volcanic surface govern how the edifice reacts to the environmental impacts, e.g. the flanks drain the rainwater 'overground' leading to the formation of rills and gullies or allow infiltration [71, 408-412]. The pyroclast-scale properties are determined by fluctuation of eruption styles during the eruption history, leading to accumulation of pyroclasts with contrasting geochemical, textural and granulometric characteristics. This pyroclast diversity will be responsible for the various rates of chemical weathering. Additionally, this diversity has an effect on the mode and efficiency of sediment transport during the course of degradation. For instance, the 'stability' (or amount of loose particles on the flanks) causes slight differences in rates, styles and susceptibility for erosion. The stability could increase with the formation of mature/immature soil, thick accumulation of weathering products, denudation of a lava-spatter horizon and/or heavy vegetation cover, which altogether help to stabilize the landscape. These changes on the mineral- to pyroclast-scales lead to transitions from 'unstabilized' to 'stabilized' stages. The duration of the transition depends on many factors (e.g. Figures 12A and B), such as the initial surface morphology, granulometric characteristics, volcanic environment and climatic settings [408-410, 413-417]. The transition could be as short as a couple of years if the volcanic surface is characterized by the dominance of fines, e.g. ejecta ring around a tuff ring, and typically exposed to a humid, tropical climate [408]. In arid climates the lag time between soil formation is significantly longer (if it takes place at all), up to $0.1-0.2 \mathrm{Ma}[188,413]$. There are extreme environments where the soil/vegetation cover can barely be developed due to the high rates of volcanic degassing and acid rain, e.g. the intra-caldera environment in Ambrym, Vanuatu [e.g. 408] or cold polar regions, e.g. Deception Island, Antarctica [e.g. 418, 419]. Changes in surface stability could be governed by gradual denudation of inner, texturally compacted (e.g. welded or agglutinated spatter horizons or zones) pyroclastic units. This leads to rock selective erosion and higher preservation potential of an edifice in the long-term [e.g. 68]. Consequently, the degradation processes cannot be separated from the architecture of the degrading volcanic edifice, and therefore the erosion history is strongly attached to the eruption history. In this respect, the erosion history and rates seem to be governed (at least on one hand) by the time-lagged denudation of pyroclastic beds with varying susceptibility to erosion. In other words, the rate and style of degradation are theoretically the 'inverse' of the eruption history if the external controls are steady over the erosion history.

The actual balance between the internal and external controls determines the dominant rates and mode of sediment transport mechanism at a given point on the flanks of a monogenetic volcano (Figure 11). The mode and style of erosion of monogenetic volcanic landforms can be subdivided into 'overground' and 'underground' erosion. The long-term, overground degradation of volcanic surfaces can be accounted for through water-gravity (including rainfall, sea or freshwater, underground water or ice or various lateral movements of sediment/soil cover due to gravitation and water), and wind erosion agents. The sediment transport fluxes of such erosion agents and their time-scales are highly variable. The most significant, normal degradation processes on bare unstable (volcanic) surfaces are possibly triggered by the presence of water. Rainfall erosion causes small-scale movement of particles up to a couple of $\mathrm{cm}$ in diameter or chunks of soil when the rain drops impact on the 


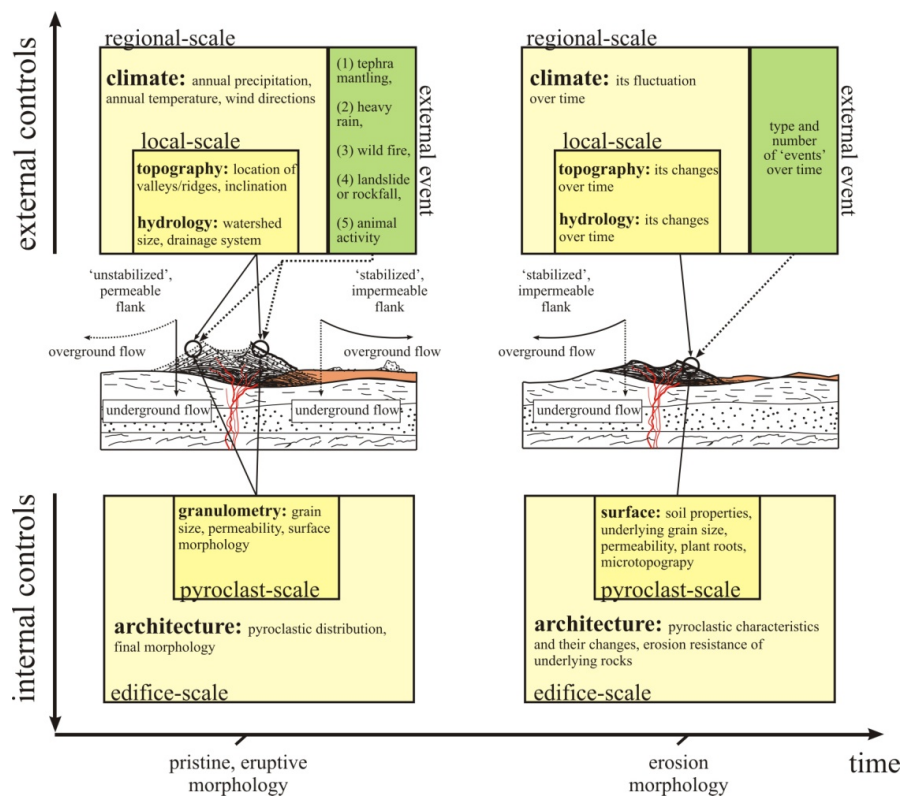

Figure 11. Conceptualized model for the configuration of internal and external degradation controls on determining erosion agents and sediment transport processes at a given point on 'unstabilized' and 'stabilized' volcanic surfaces over the erosion history. Degradation of a monogenetic volcano takes place by both long-term (ka to Ma; dark and light yellow boxes) and short-term, event-degradation processes (hours to years; green boxes) with different rates over the erosion history. The effects of such degradation processes take place both 'overground' and 'underground'.

surface [e.g. 420]. Besides the impact-triggered (or raindrop splash) sediment detachments, there are associated processes such as minor raindrop-induced surface wash [420-421]. On volcanic surfaces, the raindrop introduced and/or wind-driven rain splash erosion and related downward sediment transport on steep flanks $\left(20-25^{\circ}\right)$ is about $15.8 \mathrm{~cm} / \mathrm{yr}$ for pyroclasts with diameter of $1.7 \mathrm{~cm}$ [323]. The regional-scale lowering of the landscape (over a $100 \mathrm{~m}$ length with $10^{\circ}$ of slope angle) associated with rain-splash could be in the range of $0.1-1$ $\mathrm{mm} / \mathrm{yr}$ [e.g. 422]. This equivalent to a long-term erosion rates of $0.1 \mathrm{t} / \mathrm{km} / \mathrm{yr}$, calculating with $2.5 \mathrm{~mm}$ median rain drop diameter on a flank with $10^{\circ}$ of slope angle [422]. If rainfall intensity exceeds the soil's infiltration capacity at any time during a rainfall event, overground flow, such as unchannelized sheet flow can be generated [e.g. 423]. The erosion capacity of sheet flow is higher than the rain-splash, but it is significantly lower than mass-wasting once the rill and gully network is developed (e.g. Figures 12E and F). Drainage system development on the flanks of monogenetic volcanoes is found to correlate with the age of the volcanic edifice [70, 321, 324, 424]. Although, the required time for their formation could be as short as a couple of months or years and it could develop on the gentle flanks (e.g. a tuff ring with slope angle of $5-10^{\circ}$ in Figures $12 \mathrm{E}$ and F) which anomalously short period of time could introduce error in the relative morphology-based dating [425]. The fluvial erosion could remove sediment in a range of 10-100 $000 \mathrm{t} / \mathrm{km}^{2} / \mathrm{yr}$ [e.g. 426]. These overground sur- 
face processes, such as rill and gullies, and various soil/sediment creep [70-71, 323, 408, 425] have been accounted as a major mass wasting mechanism over the degradation history of a monogenetic volcanoes. The effect of these overground degradation processes were modelled mostly on scoria cones [324-325, 327, 337].

All varieties of soil and sediment creep and solifluction processes, such as soil and frost creep and gelifluction, are usually slow processes [e.g. 427], in comparison with surface runoff. Thus, these processes modify the volcano flanks' morphology constantly and over a longer period of time. The rates of erosion vary depending on the topography (e.g. slope gradient), sediment/soil properties (e.g. proportion of fines, moist content) and predominant climate (e.g. amount and type of precipitation, annual temperature), but rarely exceed the downhill movement rates of $1 \mathrm{~m} / \mathrm{yr}$ and the volumetric velocity of between $1 \times 10^{-10}-1 \times 10^{-8}$ $\mathrm{km}^{3} / \mathrm{km} / \mathrm{yr}$ [e.g. 427]. The sediment transport rates introduced by solifluction are many orders of magnitude smaller than the erosion loss of a volcano by fluvial processes. In cold semi-arid and arid regions, the ice plays the major role on the sediment transport [e.g. 428]. Consequently, the surface modification and movements are related to diurnal and annual frost-activity, such as ground freezing and thawing cycles. On scoria cones at the periglacial Marion Island, South Indian Ocean, dominant sediment transportation processes on scoria cone flanks are the needle-ice-induced frost creep related to the diurnal and possibly annual frost cycles [428]. The frost creep rates are $53.2 \mathrm{~cm} / \mathrm{yr}$ for ash $(\geq 70 \%$ of grains $\leq 2 \mathrm{~mm}), 16.1$ $\mathrm{cm} / \mathrm{yr}$ for lapilli ( $\geq 30 \%$ of grains between $2-60 \mathrm{~mm}$ ), and $2.6 \mathrm{~cm} / \mathrm{yr}$ for bomb/blocks $(\geq 70 \%$ of grains $\leq 60 \mathrm{~mm}$ ), based on measurements on painted rocks [428]. The rates are primarily controlled by the predominant grain-size of the sediment, the slope angle of the underlying terrain and altitude [428]. Based on the transportation rates, the processes are the same or an order of magnitude faster than rain-splash-induced pyroclast transport in a semi-arid environment, such as San Francisco volcanic field in Arizona [323].

Probably the most effective overground degradation process on a freshly created volcanic surface is the wave-cut erosion. In rocky, coastal regions, the wave cut notch moving back and sideward removes mass by hydraulic action and abrasion [e.g. 429]. Wave-cut erosion mostly affects tuff cones that are located on or offshore (Figures 12C, D, E and F). In this environment abrasion is a common syn-eruptive [430] or post-eruptive erosion process, e.g. Surtsey [431-432] or the early formation Jeju Island, Korea [433]. For instance, post-eruptive coastal modification through abrasion generated an area-loss of about $0.2 \mathrm{~km}^{2}$ between 1975 and 1980 on Surtsey island in Iceland [431]. The rate of volume-loss of non-volcanic coastal regions is in the range of 10000 to $100000 \mathrm{t} / \mathrm{km} / \mathrm{yr}$ [e.g. 434]. This enhanced rate of massremoval is in agreement with advanced states of erosion on a recently formed tuff cone within Lake Vui in the caldera of Ambae volcano, Vanuatu, which formed in 2005 [263]. The initial surface has been intensively modified by wave-cut erosion and slumping from the crater walls, leading to an enormous enlargement of the crater and crater breaching over 10 months (Figures 12C and D).

The effect of wind deflation is often limited, especially in humid climates. However, there are examples in volcanic environments where, in spite of the high annual precipitation, the sediment transport rates are still significantly high due to wind action, e.g. in some parts of 
south Iceland, around $600 \mathrm{t} / \mathrm{km} / \mathrm{yr}$ [435]. Expressing the long-term effect and rate of sediment transport by wind is complicated due the high variability of wind intensities (i.e. storm events versus normal background intensities) and directions [e.g. 436]. Sediment transport fluxes can vary in a wide range as a function of wind energy and surface characteristics (e.g. sediment availability, vegetation cover or water saturation). Long-term sediment transport by wind in volcanic areas (e.g. Iceland) is in the range of 100 to $1000 \mathrm{t} / \mathrm{km} / \mathrm{yr}$ [435-436]. However, this sediment transport rate is in relation, but it is not equivalent to the erosion rates. Furthermore, efficient wind transportation as bed load by creep and saltation, and suspended load, is limited to particles generally $\leq 8 \mathrm{~mm}$ in diameter [e.g. 436]. This granulometric limit is crucial for the long-term erosion of volcanic landforms that built up from coarser pyroclasts, such as coarse lapilli-dominated scoria cones. Significant increase is observed during storm events, when these sediment transport rates could reach as high as a couple of percentage of the annual fluxes within an hour [435]. Thus, the long-term approximation of the sediment transport rates could be interpreted as cumulative values of normal, background and increased, storm/related erosion rates [e.g. 435]. In addition, there are a few examples such as Surtsey, where the wind deflation is considerable. In Surtsey, the strong wind is responsible for the polishing of palagonitized tephra surfaces and transporting and redistributing unconsolidated tephra on the freshly created island [431]. Direct observation of short-term volumetric change of a young scoria cones (e.g. Laghetto or Monte Barbagallo, ca. $2700-2800 \mathrm{~m}$ asl) is through deflation by wind in the summit region of Mt. Etna, Sicily [326]. Surface modification is inferred to occur on the windward side of the Monte Barbagallo cones [326]. The wind likely induces some minor pyroclast disequilibrium on the flanks that may lead to minor rock fall events or initiate grain flows [326]. In real semi-arid areas, wind-erosion is an important transport agent and surface modificator over unstabilized volcanic surfaces such as the Carapacho tuff ring in the Llancanelo Volcanic Field, Mendoza, Argentina (Figure 12A). The layer-by-layer stripping of the volcanic edifice is completely visible on the windward side of the erosion remnant facing the Andes. On the other hand, the wind-blown sediments can accumulate over time leading to sometimes expressible aggradation on volcanic surfaces (Figure 13A). Accumulation of aeolian addition could significantly contribute to the soil formation by gaining excess material, e.g. quartz or mica [415, 437]. Due to the generally high roughness of pyroclast- or lava rock-dominated surfaces (e.g. highly vesicular scoria or a'a lava flow), the wind slows down, leading to sedimentation and later accumulation of wind-transported particles [415-416, 437-438]. The wind-induced aggradation helps to reduce the transition time between an 'unstabilized' to a 'stabilized' surface by developing desert pavement in semi-arid/arid desert environments [415-416].

The previously mentioned, generally long-term overground degradation processes often account for most of the volumetric loss and surface modification of monogenetic volcanoes [e.g. 71]. In the case of the underground degradation, the surface water leaves the system through the groundwater if the actual soil infiltration capacity exceeds the rainfall intensity [423]. This underground water can remove weathering products (e.g. leaching of cations from the regolith) as dissolved sediment fluxes [e.g. 439]. The rate of chemical weathering could be extremely high in humid [e.g. 439] and lower in moderate climates [e.g. 440], based on chemical and solute-derived weathering data from rivers draining mafic to intermediate igneous rocks. The 

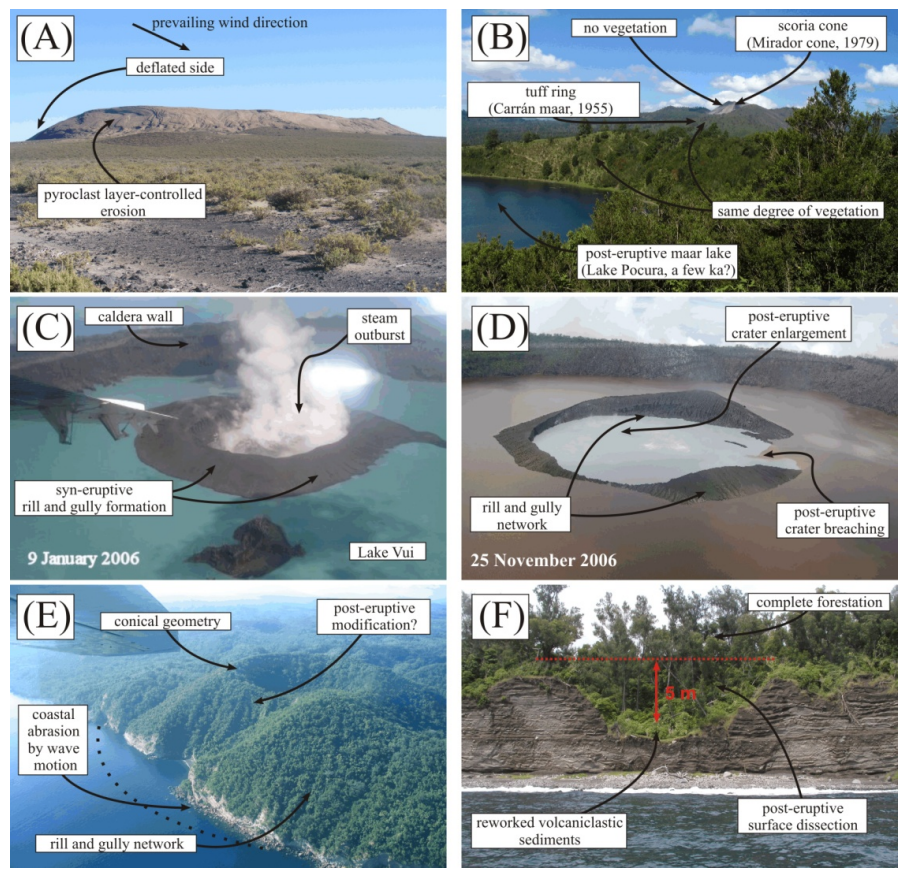

Figure 12. A) Contrasting rates of wind erosion on Pleistocene Carapacho tuff ring [61] under a semi-arid climate in the Llancanelo Volcanic Field, Mendoza, Argentina. It is interesting to note that the wind-erosion is strongly controlled by the resistance of individual beds to wind deflation. Lack of vegetation cover helps to maintain the long-term, slow erosion on the windward side of the volcanic edifice. (B) Contrasting style and rates of revegetation of volcanic surfaces on the flanks of maar/tuff ring and scoria cones. Lake Pocura (Ranco Province, Chile) is a few ka old maar crater and is characterised by the same degree of vegetation cover as the recently formed Carran maar (1955). The Mirador scoria cone (1979) lacks of vegetation cover. In comparison with Carapacho tuff ring (in A), and, the surface stabilization in semi-arid/arid climates, the time for vegetation to develop is much shorter, in a few decade time-scales. (C and D) Rapid syn- and post-eruptive erosion is observed on a freshly formed tuff cone in the caldera of Ambae, Vanuatu in 2006. (E) A tuff cone ( $\leq 2 \mathrm{ka}$ old) located along the coastal region in Ambrym, Vanuatu. Note the geomorphic similarities of this tuff cone with scoria cones. (F) Cross-section through a post-eruptive, well-developed, gully exposed by intensive wave-cut erosion since 1913. The gully developed on the gentle-flanks of a tuff ring formed in the phreatomagmatic eruption in Ambrym, Vanuatu [425].

rates of underground chemical weathering could be in the range of 10 to $1000 \mathrm{t} / \mathrm{km}^{2} /$ year in a humid climate [e.g. 439], which is in the same order of magnitude as the erosion rate by surface runoff. This efficient removal of weathering products by infiltrating rainwater and subsequent underground flow has an important, previously unaccounted for effect on degradation of monogenetic volcanic landforms. It is also worth noting that volcanoes with conical geometry are suspected to have different weathering regimes in accordance with microclimatic and topographic conditions [e.g. 437]. Taking the Rangitoto scoria cone (Auckland, New Zealand) as an example, the area of the cone is about $0.41 \mathrm{~km}^{2}$, while the bulk DEM-based volume is about $0.022 \mathrm{~km}^{3}$ above $140 \mathrm{~m}$ asl $[363,441]$. The edifice has a basal diameter of about $600 \mathrm{~m}$ and a crater diameter of $200 \mathrm{~m}$. Considering the abovementioned ranges of subsurface weather- 
ing and erosion rates, the time scales of complete erosion of the scoria cone can be calculated. Assuming a $1200 \mathrm{~kg} / \mathrm{m}^{3}$ average density for moderately to highly vesiculated scoria deposits (i.e. 3.4 to $341.6 \mathrm{~m}^{3} / \mathrm{yr}$ volume loss rates), the time scale of complete degradation would be between 6.4 Ma and 0.06 Ma, using the constant degradation rates mentioned above. Of course, the rates of chemical weathering tend to slow down when the soil coverage becomes thicker and the weatherable parental rocks are reduced [e.g. 442]. Apart from this, the underground erosion of volcanic edifices by infiltrating surface water (e.g. initial stages of scoria cone degradation) and groundwater flow could be very important and effective long-term degradation process that should have some influence on the morphology of monogenetic volcanoes, especially for volcanic areas with strong chemical weathering rates (e.g. humid, tropical areas with high annual temperature).

In summary, the degradation of a monogenetic volcano is many orders of magnitude longer ( $\geq 100 \mathrm{ka}$ to $\leq 50000 \mathrm{ka}$ ) than their formation $(\leq 0.01 \mathrm{ka})$. For example, the degradation of a small-volume $\left(\leq 0.1 \mathrm{~km}^{3}\right)$ volcanic edifice usually takes place in a couple or 10 s of Ma for welded and/or spatter-dominated edifices, such as in the Bakony-Balaton Highland Volcanic Field in Hungary [68] or in Sośnica hill volcano is Lower Silesia, Poland [335]. Phreatomagmatic volcanoes, especially those with diatremes, could degrade over a longer period of time due to their significant vertical extent, e.g. the Oligocene Kleinsaubernitz maar-diatreme volcano in Eastern Saxony, Germany [401]. During such a long degradation time, the rates and style of post-eruptive surface modification of monogenetic volcanic landforms are generally vulnerable to changes in the configuration and balance between internal and external degradation controls (Figure 11). These could be triggered internally, e.g. denudation of a spatter-dominated or a fine ash horizon (e.g. Figure 13B), or externally, such as long-term climate change or climate oscillation [39], initializing a gradual shift in the dominant mode of sediment transport. Each of these gradual changes (e.g. soil formation, granulometric and climatic changes etc.) causes a partial or complete reorganization of the controls on degradation. This adjustment of erosion settings could result in a change in erosion agent that may or may not increase or decrease sediment yield on the flanks of a volcano. All of these changes over the long erosion history open systemically new potential 'pathways' for erosion, leading to diverse erosion scenarios. The long-term degradation seems to be an iterative process, repeating a constant erosion agent adjustment that is triggered by many gradual changes over the erosion history of a volcano. In many previous erosion studies, the edifices are usually treated as individuals sharing the same internal (i.e. configuration of pyroclastic successions) and initial geometry [e.g. 71] and degrading in accordance with the climate of the volcanic field [324-325, 337]. Of course the climate is in general a important control on degradation, but the climatic forces are in continuous interactions with the volcanic surface, promoting the importance of architecture and granulometric characteristics of the exposed pyroclasts and lava rocks in the volcanic edifice. In extreme cases such as $\mathrm{Pu}$ keonake scoria cone (having typical monogenetic edifice dimensions of $150 \mathrm{~m}$ in height and $900 \mathrm{~m}$ in basal width) in the Tongariro Volcanic Complex in New Zealand, there is an unusual wide granulometric contrast within the pyroclastic succession (Figure 13B). Additionally, the trends and processes in degradation are in close relationship with the exposed pyroclast characteristics which determine the rates of chemical weathering, soil characteris- 
tics, surface permeability and, in turn, the mode of sediment transport on the flanks (e.g. Figures $13 \mathrm{C}$ and D).

\subsection{Short-term, event degradation of monogenetic volcanoes}

The event degradation processes take place in a short time frame (hours to days), but they could cause sudden disequilibrium in the degradation and sedimentary system. A monogenetic magmatic system tends to operate inhomogeneously both spatially, forming volcanic clusters, and temporally, forming volcanic cycles. Additionally, there are monogenetic volcanoes that can be found as parasitic or satellite vents on the flanks of larger, polygenetic volcanoes, such as Mt. Etna in Sicily [317] or Mauna Kea in Hawaii [314]. The spatial and temporal closeness of volcanic events, however, pose a generally overlooked problem related to the degradation of monogenetic volcanic landforms, such as tephra mantling or geomorphic truncation by eruptive processes of a surrounding volcano. Tephra mantling is considered to be an important process for the degradation of volcanic edifices as stated by Wood [71] and White [412]. The average distance between neighbouring volcanoes in intraplate settings, such as Auckland in New Zealand, is about $1340 \mathrm{~m}$ (i.e. $5.6 \mathrm{~km}^{2}$ ), while on the flank of a polygenetic volcanic/volcanic island, such as Tenerife in Canary Islands, that average is about $970 \mathrm{~m}$ (i.e. $2.9 \mathrm{~km}^{2}$ ). On the other hand, the typical area of a tephra blanket 1-2 $\mathrm{cm}$ thick ranges from $10 \mathrm{~km}^{2}$ for Hawaiian eruptions [162] to $10^{3} \mathrm{~km}^{2}$ for violent Strombolian eruptions [163, 443-444] and for phreatomagmatic eruptions [358]. Consequently, the individual edifices commonly overlap each other's eruption footprint (i.e. area affected by the primary sedimentation from the eruptions), showing the importance of tephra mantling. Furthermore, there are monogenetic volcanic edifices that are developed on flanks of larger polygenetic volcanoes where the mantling by tephra could be more frequent and more significant than in intraplate volcanic fields (e.g. Mt. Roja in the southern edge of Tenerife in the Canary Islands, Figure 13E). A few $\mathrm{cm}$ thick tephra cover could cause complete or partial damage to the vegetation canopy [411, 445-447]. Mantling could reset all dominant surface processes, including sediment transport systems, erosion agents, vegetation cover or soil formation processes. This leads to similar reorganization of the degradation controls to those seen with the long-term gradual changes of external or internal factors during normal degradation, but in much shorter time-scales (hours to years). The sedimentary responses to mantling could occur instantly or with a slight delay. Increased erosion rates of older cones were documented instantly after the tephra mantling by fine/coarse ash from Paricutin, Michoacán-Guanajuato, Mexico between 1943 and 1952 [411]. The tephra that mantled the topography was fine $(\mathrm{Md} \phi=0.1-0.5 \mathrm{~mm})$ and relatively impermeable, which led to the formation of new, extensive incisions by rill channels and significant deepening of older gullies by the increased sediment yield [411]. In contrast, the sedimentary response for the Tarawera eruption in New Zealand was delayed by the well-sorted, coarse and high permeability of the tephra accumulated over the landscape [448]. The mantling may have an effect on vegetation coverage (e.g. cover or burn the vegetation) and the erosional agent responsible for shaping the morphology of the volcano. The long-term effect of this may be the longer preservation of the landform, or increased dissection which temporarily enhances 
the overall rates of erosion. These changes will have an important influence on the majority of the morphometric parameters and their pattern of changes over the erosion history.

Surface modification of an already formed monogenetic volcanic edifice could also be triggered by the formation of another monogenetic vent close by [52, 412, 449]. The amalgamated or nested volcanic complexes that have some time delay between their formation are common in volcanic fields, for example Tihany in the Bakony-Balaton Highland, Hungary [41], Rockeskyllerkopf volcanic complex in the Eifel, Germany [450] or Songaksan in Jeju Island, Korea $[9,278]$. The eruption of nearby volcano(es) seems to be a common process that may lead to the minor truncation of surfaces, bomb/block-dominated horizons and discordances in the stratigraphic log. This type of 'event' degradation by monogenetic eruption could modify the previously formed topography instantly.

On pyroclast surfaces with limited permeability (e.g. fine ash, lava spatter horizon or lava flows), the rain water tends to simply runoff depending on the actual infiltration rate and the rain fall intensity rate [409-410, 447, 451-452]. On this fine ash surface, the infiltration rates are an order of magnitude lower than on a loose, lapilli-covered flank. This is visible on the flank of La Fossa cone in Vulcano, Aeolian Islands (Figure 13C). The La Fossa cone is not a typical monogenetic volcano, but it has similar geometry and size to a typical monogenetic volcanic edifice. Erosion on the La Fossa cone is characterized by surface runoff on the upper steeper flanks $\left(\geq 30^{\circ}\right)$ built up by fine indurated ash $(\mathrm{Md} \phi=100 \mu \mathrm{m})$, while the erosion of the lower flanks $\left(\geq 28^{\circ}\right.$ and $\mathrm{Md} \phi=1-2 \mathrm{~mm}$ ) is usually due to debris flows forming levees and terminal lobes [410]. The strikingly different style of mass wasting mechanism is interpreted to be the result of the lack of vegetation cover and strong contrast in permeability and induration of the underlying pyroclastic deposits [410]. Erosion by debris flows forms deep and wide gullies even on a flank built up by permeable rocks, e.g. La Fossa in Vulcano [410] or Benbow tuff cone in Ambrym, Vanuatu [408]. The triggering mechanism for a volcaniclastic debris flow is limited to a period of intense, heavy rainfall [408, 410, 451, 453]. Thus it operates infrequently and it tends to typically redistribute a pocket of a few tens of $\mathrm{m}^{3}$ of sediments [410].

Similarly to the volcaniclastic debris flows, landslides could also be part of the event degradation processes, especially on steep flanks (e.g. cone-type morphology). The susceptibility for landslides that remove large chunks from the original volcanic edifice, increases by diversity of the pyroclast in the succession. In other words, the layer-cake, usually bedded, inner architecture of either the ejecta ring around a phreatomagmatic volcano or a scoria cone, is extremely susceptible to landsliding triggered, for instance by heavy rain, earthquake, animal activity or surface instability of freshly deposited mantling tephra [e.g. 411].

Another event degradation process is the wild fire that is responsible for the temporal increase (by 100000 times the 'background' sediment yield) in erosion rates and sediment yields on steep flanks [e.g. 456, 457]. The major effects on a surface by a wild-fire include accumulation of ash, partial or complete damage of vegetation, and organic matter in the soil, and modification of soil structure, if any, and its nutrient content [e.g. 456]. These changes of the surface properties lead to modifications of porosity, bulk density and infiltration rates of the surface, promoting overground flow which is able to carry the increased 


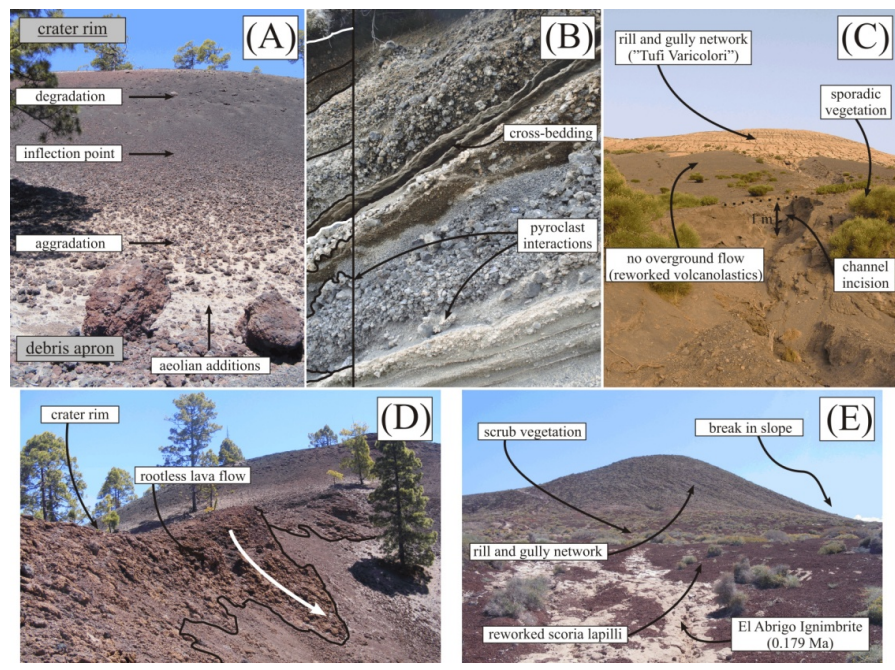

Figure 13. A) Degradation/aggradation on the outer flanks of Mt. Cascajo volcano (a few ka old?) in the NW rift zone, Tenerife, Canary Island. (B) Textural and granulometric inhomogeneity of the Pukeonake scoria cone, at the foot of the Tongariro Volcanic Complex in New Zealand. It is important to note that each of these units has different erosion resistance that may have an effect on the trends and patterns in the erosion history. (C) Contrasting granulometry and permeability caused difference in erosion surface modification on the flanks of La Fossa cone at Vulcano, Aeolian Islands. (D) Spatter accumulated on the crater rim feeds a small-volume rootless lava flow at the Mt. Cascajo volcano in Tenerife, Canary Island. The spatter is relatively impermeable in comparison with its environment (e.g. loose, scoria lapilli), thus will have an influence on the subsequent erosion patterns. (E) View of Mt. Roja in the southern edge of Tenerife, Canary Island. The Mt. Roja edifice was partly or completely covered by the El Ambrigo Ignimbrite (0.18 Ma) sourced from the former Las Cañadas edifice [454-455]. This mantling resulted in development of a rill and gully system on the flanks facing toward north.

sediment yield [e.g. 456]. The overground flow removes the fine sediment (e.g. volcanic ash and lapilli and non-volcanic ash) and the topsoil, causing enrichment of coarser sediment on the surface.

Animal activity is a commonly recognized erosion type due to its effect on the compaction of the uppermost soil [e.g. 458, 459] and/or linear dissection of the surface by trampling [e.g. $460,461]$. As a result of compaction, the rainwater cannot penetrate through the soil cover easily, leading to overground flow that increases the erosion rate and sediment yield [e.g. 458]. Wild animal tramping could be a source of rill and gully formation on flanks, mostly in semi-arid and arid environments [e.g. 460], particularly in, the crater-type volcanoes that commonly host post-eruptive lakes within the crater basins, such as Laguna Potrok Aike in Pali Aike Volcanic Field, Patagonia, Argentina [462] or Pula maar, Bakony-Balaton Highland, Western Hungary [195, 463]. These maar lakes create special habitats that could increase animal activity, creating more opportunity for animal activity-induced erosion.

The event degradation processes, such as heavy rain-induced debris flow, tephra mantling, landslide, post-wild fire runoff or animal activity, could individually trigger rapid geomorphic modifications that affect the long-term degradation rates of the volcanic edifices (Figure 
11). The rates of sediment yield could be a thousand times larger in response to event degradation than in the case of normal degradation. These events are usually randomly or inhomogeneously distributed over the erosion history of a volcanic landform, making the quantification to the total erosion-loss complicated. Due to significant surface modification, their effect on the morphometric parameters could be large and difficult to quantify.

\subsection{Post-eruptive erosion of monogenetic volcanoes by normal and event degradation processes}

The geomorphic state of (monogenetic) volcanoes is commonly expressed by various morphometric parameters, including edifice height, slope angle or $\mathrm{H}_{\mathrm{co}} / \mathrm{W}_{\mathrm{co}}$ ratios. The values of these morphometric parameters usually show a decreasing trend over the course of the erosion history [70-71, 290, 299, 317, 320, 464-465]. Consequently, the morphometric parameters show strong time-dependence. This systematic change in morphology was observed mostly on scoria cones in many classical volcanic fields, such as San Francisco volcanic field in Arizona [71] or Cima Volcanic Field in California [70]. This recognition led to the most obvious interpretation: the morphology is dependent on the degree of erosion, which is a function of time and the climate [e.g. 71]. Therefore, morphometric parameters may be used as a dating tool for volcanic edifices if the final geometry and internal architecture are similar among the volcanic edifices being compared [e.g. 71, 324]. These fundamental assumptions (regardless if stated or not) are valid for all comparative morphometric studies targeted volcanoes.

The concept outlined above is, however, sometimes oversimplified and the assumptions are not always fulfilled. The concern about the classical interpretation of morphometric parameters and their change over time is derived from various sources.

- The architecture of a single monogenetic edifice is commonly inhomogeneous in terms of internal facies characteristics. This architectural diversity usually results in diversity in erosion-resistance and susceptibility to chemical weathering of the pyroclastic rocks exposed to the external environment (e.g. Figures 10 and 13B or [e.g. 68]. Due to the continuous denudation of internal beds, the internal architectural irregularities could cause different rates of weathering and erosion leading to hardly predictable trends in degradation.

- The previous concept of monogenetic volcanism implied that the morphology of a volcanic landform is linked only to the specific eruption styles (i.e. Strombolian-type scoria cone). However, this is an oversimplification and belies the complex pattern in edifice growth (e.g. Figures 6-9).

- The final, pristine edifice morphology is mostly controlled by syn-eruptive processes (e.g. explosion energy, substrate stability, mass wasting and mode of pyroclast transport, e.g. Figures 7-9). Any change in either the internal or external controls during the course of an eruption could modify the final morphology of the edifice partially or dramatically. This is in agreement with the measured high variability of slope angle [e.g. 398] or aspect ratios [e.g. 314] on relatively fresh edifices. This supposedly eruptive process-related morphometric variability is observed on both the intra-edifice scale (e.g. between various parts of an edifice) and inter-edifice scale [398]. 
- There is a large difference in the rates and mode of chemical weathering and sediment transport operating on different types of pyroclastic deposits or lava rock surfaces (e.g. Figures 12 and 13). For instance, there is a contrast between mass wasting rates by underand overground flow processes, e.g. spatter or a higher degree of welding/agglutination could cause asymmetric patterns in the permeability and, therefore, the subsequent initialization of the erosion on a freshly created surface.

- One theoretical concern about morphometric parameters, such as edifice height, aspect ratio or slope angle, is that they are intra-edifice, 'static' descriptors. Thus, they only express the current geomorphic state of the volcano. In contrast, they are often used to reveal and describe 'dynamic' processes, such as erosion patterns over time. It is obvious that trends in erosion processes cannot be seen based on these intra-edifice, 'static' parameters unless they are compared with other edifice parameters, or measure direct geomorphic modification by erosion processes over short periods of time (e.g. Figures $12 \mathrm{C}$ and D or [e.g. 464]). The first seems an 'extrapolation' due to the assumption of that all volcanic edifices in the comparison have similar eruptive- and erosion histories. The second is more suitable, because it is the direct observation of erosion loss and surface modification [e.g. 326].

- Comparative morphometric studies often lack or have limited age constraints (e.g. a few $\%$ of the total population of the studied edifices are dated) on the morphology, or inversely in special cases, the dating is the purpose of the comparison. There are just a few studies with complete age constraint [e.g. 68, 70, 326].

- The long-term surface modification is often believed as a result of the climate forces and climate-induced erosion processes. Wood [71] stated the importance of tephra mantling as a possible source of acceleration of erosion rates, but such event-degradation (e.g. tephra mantling, edifice truncation by eruption nearby, landsliding, wild fire, animal activity etc.), are usually neglected. They occur infrequently, but they could cause rapid and significant modification that may influence the patterns of future degradation.

Due to the concerns and arguments listed above, the morphometric parameters and their classical interpretations should be revised. Referring back to the complexity of construction of monogenetic volcanoes (Figure 6) and their primary geomorphic development (Figures 7-9), it is obvious that on a fresh volcanic landform the geomorphic feature is determined by syn-eruptive processes, which in turn are governed by the internally and externally-driven processes during the eruption history. Once the eruption ceases, the 'input' configuration of a monogenetic volcano in terms of architecture, pyroclast granulometric characteristics, geometry and geomorphology is given. The erosion agents at the start of the erosion history are determined by the interactions between the internal (e.g. pyroclastic rocks on the surface) and external processes (e.g. climate; Figure 11). The results of such series of interactions between these properties lead to surface and subsurface weathering, soil formation and development of vegetation succession over time. Each of these developments on the flanks of a monogenetic volcano has a feedback to the original controls modifying the actual balance towards one side. This leads to disequilibrium in the system and subsequent adjusting mechanism. These processes are called normal degradation, operating at a longer-time scale (ka to Ma). However, the degradation mechanism sometimes does not function as 'nor- 
mal'. During the erosion history of a monogenetic volcano, there are some environmental effects called 'events' such as tephra mantling or heavy-rain-induced grain flows. These 'events' are documented to cause orders of magnitude larger surface modification and possibly initialize new rates and trends in the dominant sediment-transport system and increase the sediment yield [e.g. 411-412, 447-448, 457]. Consequently, the erosion history of a monogenetic volcano comprises both normal ('background') and event degradation processes (Figure 11). The cumulative result of many interactions, reorganization of erosion agents, and effects of event degradation processes over the erosion history, are integrated into the geomorphic state at the time of examination.

The degradation of the volcanic edifice leads to aggradation at the foot of the edifice and the development of a debris apron (Figure 13A). Based on the behaviour and changes of intensity of the abovementioned major sediment transport processes, it is evident that the individual contribution of such erosion processes is not constant over time. It is more likely that they are enhanced or eased by each other at certain stages of the degradation. The gradual changes in style, rate and mode of sediment transport on the flank of a monogenetic volcanic edifice are likely triggered by the shifting of dominant external (e.g. climate change) and internal environments (e.g. variability of erosion resistant layer within the edifice as observed in Figure 14A). Consequently, the degradation of the monogenetic edifice as a whole cannot be linear (or maybe just certain parts of the erosion history) and must erode faster at the beginning and slower at the end of the degradation $[71,324]$ in accordance with the wide range of rates and time-scales of sediment transport processes. Consequently, a single geomorphic agent cannot account for a volcano's degradation. Instead, it seems to be the result from the overall contribution of all processes with complex temporal distribution. Without event degradation processes, given the fact that the erosion history lasts at least over a timescale of a couple of ka for a typical monogenetic volcanoes, this increases the likelihood of some changes in the external environment that could modify the degradation trend.

These surface modifications and degradation processes should be in correlation with the values of morphometric parameters, but their interpretation is possibly not a straightforward process. The pristine unmodified geomorphic stage of a monogenetic volcano is predominantly controlled by the processes that occurred in the eruption history. Once the degradation proceeds (e.g. erosion surface modification, soil formation or development of vegetation cover), these primary geomorphic attributes are gradually replaced by excess 'signatures' of the various post-eruptive processes. This will result in 'noise' in the original syn-eruptive state of morphometric parameters extracted from the topographic attributes. The soil cover on the surface creates a buffer zone between the pyroclastic deposits and the environment. In this buffer zone, most of the weathering and erosion processes take place (e.g. overground flow). During the degradation the actual erosion surface, regardless of whether it is 'unstabilized' or 'stabilized', could contain pyroclasts with contrasting granulometric and textural characteristics (e.g. Figure 13B). For instance, the rates of weathering, weathering product transport and soil formation could be different at the base of a volcanic cone than at the crater rim, due to the differences in flank morphology, aspect or microclimate. These differences are demonstrated for various sectors of a cone-type volcano by the 
variation in microclimatic setting, e.g. insolation, freeze-thaw cycles or snow cover [437]. If there are a couple of meter difference in sediment accumulation/loss, chemical weathering and soil formations, it could cause a variation of a few degrees in the slope angle values. In extreme cases, these differences could cause misinterpretation of the morphometric parameters, thus these should be taken into account or stated as an assumption of the interpretation. The increase of post-eruptive 'noise' of the morphometric parameters will possibly increase over the erosion history, and possibly the largest in the late stage degradation of the edifice (e.g. Ma after its formation). In the case of older scoria cones, the architectural control could increase, as the well-compacted and welded units are exposed, leading to rock-selective erosion styles and longer preservation potential for a volcanic landform. This is found to be important to the good preservation of the Pliocene (2.5-3.8 Ma) scoria cones such as Agár-tető or Bondoró at the Bakony-Balaton Highland in Hungary [68]. For instance, these scoria cones are old but they resemble considerably younger cone morphologies, due to their higher morphometric values (e.g. height about $40-80 \mathrm{~m}$, slope angle of $10-15^{\circ}$ ). These parameters could be similar to the degradation signatures of a much younger cone, e.g. Early Pleistocene cones (slope angle of $13 \pm 3.8^{\circ}$ ) from Springerville volcanic field, Arizona [324].

Many lines of evidence suggest that the neglected internal architecture, initial variability in geomorphic state or effect of 'event' degradation processes play an important role on edifice degradation rates and trends. Once the degradation histories for various edifices are characterized by

1. different 'input' morphometric conditions (e.g. Figure 14B), and

2. large variability of rates and trends in mass wasting processes in accordance with the susceptibility of chemical weathering of the underlying volcanic rocks and the total capacity of sediment transport, it is possible that the same geomorphic state can be reached not only by ageing of the edifice, but via a combination of other processes.

This further implies that the monogenetic volcanic edifice has a unique eruptive (e.g. Figure 6) and erosion history (e.g. Figures 12-14). As a result of the eruptive diversity, the erosion history is not independent from the eruption history (i.e. the complexity of the monogenetic edifices). In this interpretation, there is a chance to have edifices showing the same 'geomorphic state' (in terms of the basic geometric parameters) reached through different 'degradation paths'. An example for this could be the case of the two scoria cones in Figures 14C and D. In Figure $14 \mathrm{C}$, the geometry of the edifice is strongly attached to the erosion-resistance and to the position of the spatter-dominated collar along the crater rim. In this eruptive history and subsequent erosion, the slope angle can be increased due to the undermining of the flanks. Consequently, the morphology of the cone is becoming 'younger' over time, that is the slope angle or $\mathrm{H}_{\mathrm{co}} / \mathrm{W}_{\mathrm{co}}$ ratio will increase rather than decrease. On the other hand, a classical-looking cone (Figure 14D) that has a homogenous inner architecture, experiences different rates and degrees of erosion over different time scales. Therefore, both cones degrade through different patterns and rates. To confidently say that the decreasing trend in morphometric parameters is associated with age, it is important to reconstruct the likely environment where the edifice degradation has taken place, including the number of 'event' and 
major changes in the degradation controls. This includes understanding the combination and diversity of facies architecture $[68,468]$, the stratigraphic position of the edifice within the stratigraphic record of the volcanic field [412,469], the approximate likelihood of aggradation by, for example, tephra mantling [411], and spatial and temporal combination and fluctuation of 'normal' and 'event' degradation processes over the erosion history.
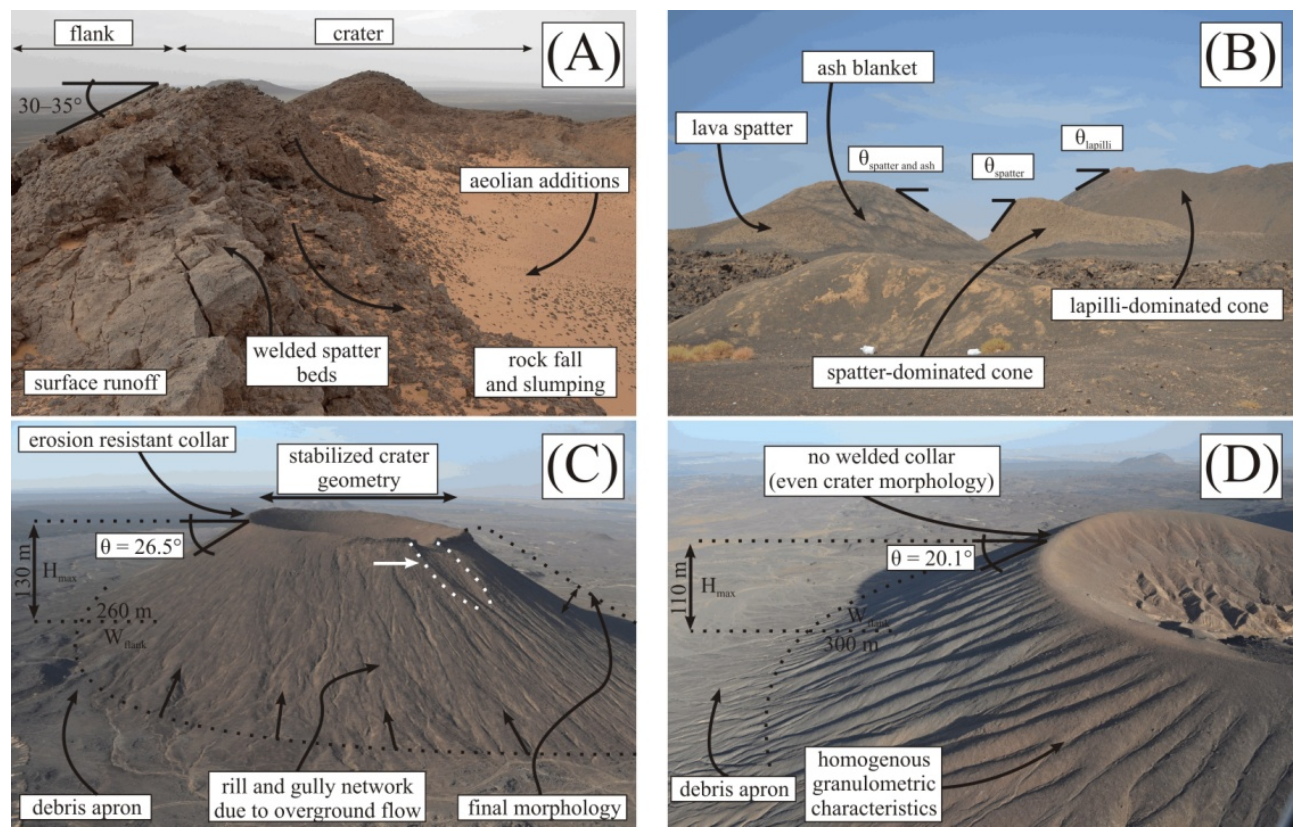

Figure 14. A) Difference in mode of erosion (rock fall or surface runoff) due to spatter accumulation on the crater rim of a 1-3 Ma old scoria cone in the Al Haruj Volcanic Field in Libya [288, 466]. (B) Variability in slope angle on the flanks of spatter-dominated and lapilli-dominated cones (1256 AD) in the last eruptions at the Harrat Al-Madinah Volcanic Field, Saudi Arabia [467]. Due to the young ages, these differences could be the results of differences in syn-eruptive processes (e.g. fragmentation mechanism, degree of welding and granulometric properties). These different 'input' geomorphic states alone can also lead to the large variability of degradation paths of monogenetic volcanic landforms. (C and D) Architecturally-controlled erosion pattern on Pleistocene scoria cones in the Harrat Al-Madinah Volcanic Field, Saudi Arabia. The ages are between 1.2 and 0.9 Ma for the cone in Figure $C$, and only a couple of ka for the cone in Figure D [467]. The geomorphic contrast between the edifices is striking in the slope angles, $\theta$, calculated as $\theta$ $=\arctan \left(\mathrm{H}_{\text {max }} / \mathrm{W}_{\text {flank }}\right)$ from basic morphometric data. The erosion resistant collar on the crater rim changes the erosion patterns by keeping the crater rim at the same level over even Ma. This results in the 'undermining' of the flanks (small black arrows at the foot of the cones represented by a dashed line in Figure D) leading to a gradual increase of the slope angles in contrast to all previously proposed erosion models for cone-type monogenetic volcanoes. The white arrow near the rim (Figure C) indicates the significant surface modification by event degradation (e.g. mass wasting of the erosion-resistant spatter collar). It is speculative, but the consequence of this irreversible and possibly 'random' event may have initialized the formation of a deeper gully (white dashed lines) leading to crater breaching over a longer time-scale. 


\section{Conclusions: towards understanding the complexity of monogenetic volcanoes}

A typical monogenetic volcanic event begins at the magma source region, usually in the mantle, and ends when the volcanics have been fully removed by, for example, erosion processes. Within this conceptualized life cycle of a monogenetic volcano, there is an active stage (e.g. propagation of the magma towards the surface feeding a monogenetic eruption; Figure 15) and a passive stage (e.g. post-eruptive degradation until the feeder system is exposed; Figure 15). The active stage of evolution is dependent on many interactions between internally- or externally-driven factors. The magma (left hand side on Figure 15) intrudes into shallow parts of the crust that can be fragmented in accordance with the actual balance between the magmatic and external conditions at the time of the fragmentations. This could result in 6 varieties of volcanic eruptions if the composition is dominantly basaltic, which is responsible for the construction of a monogenetic volcanic edifice with a simple eruption history ( $E_{\text {simple, }}$ that is $6^{1}$ combinations of eruption styles). Once there is some disequilibrium in the system during the course of the eruption that will result in changing eruption styles adjusting the balance in the system, forming compound eruption histories $\left(\mathrm{E}_{\text {compound }}\right.$ that is $6^{2}$ combinations of eruption styles). Each number of shifts in dominant eruption style opens a new phase of edifice growth and therefore increases the complexity of the eruption history towards $\mathrm{E}_{\text {complex }}$ (that is $6^{3}$ or more combinations of eruption styles). There could be even thousands of theoretical combinations of eruption styles if the volcano is built up by more than 4 phases with different eruption styles, until the magma supply is completely exhausted or new vent is established by migration of the magma focus. With increasing complexity of the eruption history, the complexity of the facies architecture of the volcanic edifice increases. Conceptually, these eruption histories can be numerically described by matrices, based on spatial and temporal characteristics of eruption styles (e.g. Figure 6). The coding of eruption styles could be

1. Hawaiian,

2. Strombolian,

3. violent Strombolian,

4. phreatomagmatic,

5. Surtseyan and

6. effusive activity

, if the erupting melt is characterised by basaltic to basaltic andesitic in composition. This systems can be modified by adding further eruption styles such as sub-Plinian. The syn-eruptive geomorphology of a volcano is, however, not only the result of the eruption style and associated pyroclast transport mechanism, but there are stages of destructive processes, such as flank collapse during scoria cone growth (e.g. Figure 3) or wall rock mass wasting during excavation of a maar crater (e.g. Figure 4). These common syn-eruptive processes (constructive and destructive phases during the eruption history) have an important role on the resulting morphology, but they are not always visible/detectable in the morphology of the edifice. 


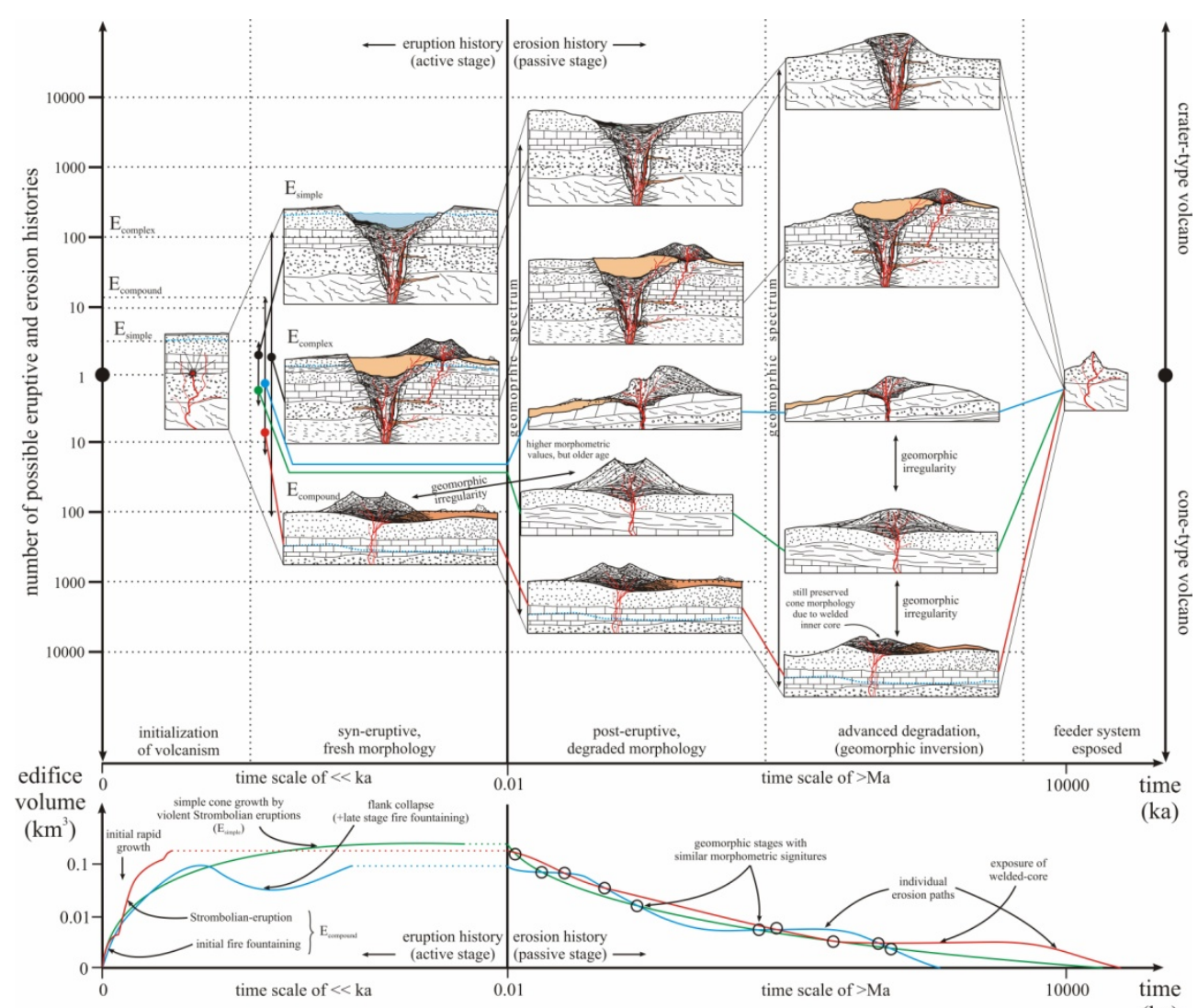

(ka)

Figure 15. Conceptualized model to understand causes and consequences in the life cycle of crater- and cone-type monogenetic volcanoes. See the text for a detailed explanation. Note that the colour coding in the bottom graph corresponds the conceptualized degradation paths for the three cone-type volcanoes in the top graph. The double-headed arrows (top graph) and black circles (bottom graph) show the time slices when geomorphic states of the edifices are similar, expressed by the morphometric parameters.

On the other hand, after the eruption ceases a passive stage of surface modification takes place (right hand side on Figure 15). In the passive stage, the erosion history is also governed significantly by a series of interactions between the exposed pyroclastic deposits and lava rocks (and their textural and granulometric characteristics determining permeability) and external influences such as climate, location or hydrology of the area. These interactions determine the long-term ( $\mathrm{ka}$ to $\mathrm{Ma}$ ) degradation processes and rates. However, it is important to note that the erosion history is often a function of 'normal' and 'event' degradation. The effect of event degradation is expected to be larger, in some cases, than the cumulative surface modification by normal degradation processes. The relationship between event and 
normal degradation should be a subject for future studies. Due to the large number of combinations of eruption styles that can generate edifices with different pyroclastic successions and different initial geometries (at least a broader range than previously thought), volcanoes can have very different susceptibilities for erosion. This implies that degradation trends and patterns of monogenetic volcanoes should be individual volcano-specific (right hand side on Figure 15). In addition, the combination of erosion path of individual monogenetic volcanoes is an order of magnitude larger than during the eruption history due to the larger number of controlling factors (6 eruption styles versus varieties of 'normal' and 'event' mass wasting processes) and the longer time-scale of degradation ( $<<$ ka versus $>\mathrm{Ma})$. This has an important practical conclusion: there are certain stages during the degradation when some morphometric irregularity occurs if two or more volcanic edifices are compared. The morphometric irregularity refers to the state when two volcanoes appear similar through morphometric parameters such as $\mathrm{H}_{\mathrm{co}} / \mathrm{W}_{\mathrm{co}}$ ratio or slope angle, but they have different absolute ages (black double-headed arrows of the top graph and black circles on the bottom graph in Figure 15). An important practical application of the volcano-specific degradation is that the correlation between the morphology of the edifice is not always a function of the time elapsed since formation of the volcanic edifice. As a consequence of the diverse active and passive evolution of a volcanic edifice, age grouping based on geomorphic parameters, such as $\mathrm{H}_{\mathrm{co}} / \mathrm{W}_{\mathrm{co}}$ ratio or average or maximum cone slope angle, should be avoided. In terms of interpretation of the morphometric data, the post-eruptive surface modification causes unfortunate 'noise' in the primary morphometric signatures, which can be only reduced by using edifices with absolute age constraints. Due to the long-lived evolution of monogenetic volcanic fields (Ma-scale), there are usually volcanoes that are freshly formed, sometimes close to volcanoes with no primary morphological features at the time of the examination. The large contrasting and dynamic geological environment of such monogenetic volcanoes makes the interpretation of available topographic information more complicated than previously thought. Future studies should target this particular issue and define the meaning of morphology of these monogenetic volcanic edifices at many scales.

\section{Acknowledgements}

Constructive discussion about various aspects of monogenetic volcanism and remote sensing with Shane Cronin, Jon Procter, Jan Lindsay, Javier Agustín-Flores, Marco Brenna, Natalia Pardo, Nicola Le Corvec, Mark Bebbington and Mike Tuohy is acknowledged. Remarks and suggestion by Bob Stewart, Adrian Pittari, Marco Brenna, Kate Arentsen and Javier Agustín-Flores and an anonymous reviewer are gratefully appreciated. This study was supported by the NZ MSI-IIOF Grant "Facing the challenge of Auckland's Volcanism" (MAUX0808). The authors would like to thank the Auckland City Council for the LiDAR dataset and the Department of Conservation (Te Papa Atawhai) for the logistical help during field trips. 


\section{Author details}

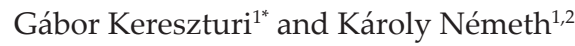

*Address all correspondence to: kereszturi_g @yahoo.com

1 Volcanic Risk Solutions, Massey University, Palmerston North, New Zealand

2 King Abdulaziz University, Jeddah, Kingdom of Saudi Arabia

\section{References}

[1] Canon-Tapia, E., \& Walker, G. P. L. (2004). Global aspects of volcanism: the perspectives of "plate tectonics" and "volcanic systems. Earth-Science Reviews, 66, 163-82.

[2] Morgan, W. J. (1971). Convection Plumes in the Lower Mantle. Nature, 230, 42-3.

[3] Tarduno, J., Bunge-P, H., Sleep, N., \& Hansen, U. (2009). The Bent Hawaiian-Emperor Hotspot Track: Inheriting the Mantle Wind. Science, 324, 50-3.

[4] De Paolo, D. J., \& Manga, M. (2003). Deep Origin of Hotspots- The Mantle Plume Model. Science, 300, 920-1.

[5] Németh, K. (2010). Monogenetic volcanic fields: Origin, sedimentary record, and relationship with polygenetic volcanism. The Geological Society of America Special Paper, 470, 43-66.

[6] Conrad, CP, Bianco, T. A., Smith, E. I., \& Wessel, P. (2011). Patterns of intraplate volcanism controlled by asthenospheric shear. Nat Geosci, 4, 317-21.

[7] Bebbington, M. S., \& Cronin, S. J. (2011). Spatio-temporal hazard estimation in the Auckland Volcanic Field, New Zealand, with a new event-order model. Bull Volcanol, 73(1), 55-72.

[8] Keating, G. N., Valentine, G. A., Krier, D. J., \& Perry, F. V. (2008). Shallow plumbing systems for small-volume basaltic volcanoes. Bull Volcanol, 70, 563-82.

[9] Brenna, M., Cronin, S. J., Németh, K., Smith, I. E. M., \& Sohn, Y. K. (2011). The influence of magma plumbing complexity on monogenetic eruptions, Jeju Island, Korea. Terra Nova, 23, 70-5.

[10] Connor, C. B., Stamatakos, J. A., Ferrill, D. A., Hill, B. E., Ofoegbu, G., Conway, F. M., et al. (2000). Geologic factors controlling patterns of small-volume basaltic volcanism: Application to a volcanic hazards assessment at Yucca Mountain, Nevada. J Geophys Res, 105(1), 417-32. 
[11] Smith, I. E. M., Blake, S., Wilson, C. J. N., \& Houghton, B. F. (2008). Deep-seated fractionation during the rise of a small-volume basalt magma batch: Crater Hill, Auckland, New Zealand. Contrib Mineral Petrol, 155(4), 511-27.

[12] Gencalioglu-Kuscu, G. (2011). Geochemical characterization of a Quaternary monogenetic volcano in Erciyes Volcanic Complex: Cora Maar (Central Anatolian Volcanic Province, Turkey). Int J Earth Sci, 100(8), 1967-85.

[13] Browne, B., Bursik, M., Deming, J., Louros, M., Martos, A., \& Stine, S. (2010). Eruption chronology and petrologic reconstruction of the ca. $8500 \mathrm{yr}$ B.P. eruption of Red Cones, southern Inyo chain, California. Geol Soc Am Bull, 122(9-10), 1401-1422.

[14] Agustín-Flores, J., Siebe, C., \& Guilbaud-N, M. (2011). Geology and geochemistry of Pelagatos, Cerro del Agua, and Dos Cerros monogenetic volcanoes in the Sierra Chichinautzin Volcanic Field, south of México City. J Volcanol Geotherm Res, 201(1-4), 143-162.

[15] Strong, M., \& Wolff, J. (2003). Compositional variations within scoria cones. Geology, 31(2), 143-6.

[16] Németh, K., White, J. D. L., Reay, A., \& Martin, U. (2003). Compositional variation during monogenetic volcano growth and its implication for magma supply to continantal volcanic fields. J Geol Soc London, 160, 523-30.

[17] Brenna, M., Cronin, S. J., Smith, I. E. M., Sohn, Y. K., \& Németh, K. (2010). Mechanisms driving polymagmatic activity at a monogenetic volcano, Udo, Jeju Island, South Korea. Contrib Mineral Petrol, 160, 931-50.

[18] Cebriá, J. M., Martiny, BM, López -Ruiz, J., \& Morán-Zenteno, D. J. (2011). The Parícutin calc-alkaline lavas: New geochemical and petrogenetic modelling constraints on the crustal assimilation process. J Volcanol Geotherm Res, 201(1-4), 113-125.

[19] Shaw, C. S. J. (2004). The temporal evolution of three magmatic systems in the West Eifel volcanic field, Germany. J Volcanol Geotherm Res, 131, 213-40.

[20] Hasenaka, T., Ban, M., \& Granados, H. D. (1994). Contrasting volcanism in the Michoacán-Guanajuato Volcanic Field, central Mexico: Shield volcanoes vs. cinder cones. Geofisica Internacional, 33(1), 125-38.

[21] Connor, C. B., \& Conway, F. M. (2000). Basaltic volcanic fields. Sigurdsson H, Houghton BF, McNutt SR, Rymer H, Stix J, editors. Encyclopedia of Volcanoes. San Diego: Academic Press, 331-343.

[22] Hoernle, K., White, J. D. L., van den Bogaard, P., Hauff, F., Coombs, DS, Werner, R., et al. (2006). Cenozoic intraplate volcanism on New Zealand: Upwelling induced by lithospheric removal. Earth Planet Sci Lett, 248, 350-67.

[23] Németh, K., Cronin, S. J., Haller, MJ, Brenna, M., \& Csillag, G. (2010). Modern analogues for Miocene to Pleistocene alkali basaltic phreatomagmatic fields in the Pan- 
nonian Basin: "soft-substrate" to "combined" aquifer controlled phreatomagmatism in intraplate volcanic fields. Cent Eur J Geosci, 2(3), 339-61.

[24] Condit, C. D., \& Connor, C. B. (1996). Recurrence rates of volcanism in basaltic volcanic fields: An example from the Springerville volcanic field, Arizona. Geol Soc Am Bull, 108, 1225-41.

[25] Kshirsagar, P. V., Sheth, H. C., \& Shaikh, B. (2011). Mafic alkalic magmatism in central Kachchh, India: a monogenetic volcanic field in the northwestern Deccan Traps. Bull Volcanol, 73(5), 595-612.

[26] Sheth, H. C., Mathew, G., Pande, K., Mallick, S., \& Jena, B. (2004). Cones and craters on Mount Pavagadh, Deccan Traps: Rootless cones? Earth and Planetary Sciences (Proceedings of the Indian Academy of Sciences), 113(4), 831-8.

[27] Márquez, A., Verma, S. P., Anguita, F., Oyarzun, R., \& Brandle, J. L. (1999). Tectonics and volcanism of Sierra Chichinautzin: extension at the front of the Central TransMexican Volcanic belt. J Volcanol Geotherm Res, 93(1-2), 125-150.

[28] Germa, A., Quidelleur, X., Gillot, P. Y., \& Tchilinguirian, P. (2010). Volcanic evolution of the back-arc Pleistocene Payun Matru volcanic field (Argentina). J S Am Earth Sci, 29(3), 717-30.

[29] Baloga, S. M., Glaze, L. S., \& Bruno, B. C. (2007). Nearest-neighbor analysis of small features on Mars: applications to tumuli and rootless cones. J Geophys Res, 112(E03002), 10.1029/2005JE002652.

[30] Bishop, M. A. (2007). Higher-order neighbor analysis of the Tartarus Colles cone groups, Mars: The application of geographical indices to the understanding of cone pattern evolution Icarus. 197(1), 73-83.

[31] Broz, P., \& Hauber, E. (2012). A unique volcanic field in Tharsis, Mars: Pyroclastic cones as evidence for explosive eruptions. Icarus, 218, 88-99.

[32] Keszthelyi, L. P., Jaeger, W. L., Dundas, C. M., Martínez-Alonso, S., Mc Ewen, AS, \& Milazzo, M. P. (2010). Hydrovolcanic features on Mars: Preliminary observations from the first Mars year of HiRISE imaging. Icarus, 205, 211-29.

[33] Wilson, L., \& Head, J. W. (1994). Mars: Review and analysis of volcanic eruption theory and relationships to observed landforms. Rev Geophys, 32(3), 221-63.

[34] Sandri, L., Jolly, G., Lindsay, J., Howe, T., \& Marzocchi, W. (2011). Combining longand short-term probabilistic volcanic hazard assessment with cost-benefit analysis to support decision making in a volcanic crisis from the Auckland Volcanic Field, New Zealand. Bull Volcanol, 74(3), 705-23.

[35] Lindsay, J., Marzocchi, W., Jolly, G., Constantinescu, R., Selva, J., \& Sandri, L. (2010). Towards real-time eruption forecasting in the Auckland Volcanic Field: application of BET_EF during the New Zealand National Disaster Exercise 'Ruaumoko' Bull Volcanol. 72(2), 185-204. 
[36] Siebe, C., Rodriguez-Lara, V., Schaaf, P., \& Abrams, M. (2004). Radiocarbon ages of Holocene Pelado, Guespalapa, and Chichinautzin scoria cones, south of Mexico City: implications for archaeology and future hazards. Bull Volcanol, 66, 203-25.

[37] Delgado, H., Molinero, R., Cervantes, P., Nieto-Obregón, J., Lozaro-Santa, Cruz. R., Macías-González, H. L., et al. (1998). Geology of Xitle volcano in southern Mexico City-a 2000- year-old monogenetic volcano in an urban area. Rev Mex Cienc Geol, 15(2), 115-31.

[38] Valentine, G. A., \& Hirano, N. (2010). Mechanisms of low-flux intraplate volcanic fields-Basin and Range (North America) and northwest Pacific Ocean. Geology, 38(1), $55-8$.

[39] Kereszturi, G., Németh, K., Csillag, G., Balogh, K., \& Kovács, J. (2011). The role of external environmental factors in changing eruption styles of monogenetic volcanoes in a Mio/Pleistocene continental volcanic field in western Hungary. J Volcanol Geotherm Res, 201(1-4), 227-240.

[40] Brenna, M., Cronin, S. J., Smith, I. E. M., \& Maas, R., Sohn, Y. K. (2012). How Smallvolume Basaltic Magmatic Systems Develop: a Case Study from the Jeju Island Volcanic Field, Korea. J Petrol, 53(5), 985-1018.

[41] Németh, K., Martin, U., \& Harangi, S. (2001). Miocene phreatomagmatic volcanism at Tihany (Pannonian Basin, Hungary). J Volcanol Geotherm Res, 111(1-4), 111-35.

[42] Valentine, G. A., \& Perry, F. V. (2007). Tectonically controlled, time-predictable basaltic volcanism from a lithospheric mantle source (central Basin and Range Province, USA). Earth Planet Sci Lett, 261(1-2), 201-16.

[43] Geyer, A., \& Martí, J. (2010). The distribution of basaltic volcanism on Tenerife, Canary Islands: Implications on the origin and dynamics of the rift systems. Tectonophysics, 483(3-4), 310-326.

[44] Németh, K. (2012). An Overview of the Monogenetic Volcanic Fields of the Western Pannonian Basin: Their Field Characteristics and Outlook for Future Research from a Global Perspective. Stoppa F, editors. Updates in Volcanology- A Comprehensive Approach to Volcanological Problems. In-Tech, 27-52, http://www.intechopen.com/books/updatesin-volcanology-a-comprehensive-approach-to-volcanological-problems/an-overviewof-the-monogenetic-volcanic-fields-of-the-western-pannonian-basin-their-fieldcharacteri.

[45] Jankovics, M. É., Harangi, S., Kiss, B., \& Ntaflos, T. (2012). Open-system evolution of the Füzes-tó alkaline basaltic magma, western Pannonian Basin: Constraints from mineral textures and compositions. Lithos, 140-141, 25-37.

[46] Bali, E., Zanetti, A., Szabó, C., Peate, D. W., \& Waight, T. E. (2008). A micro-scale investigation of melt production and extraction in the upper mantle based on silicate melt pockets in ultramafic xenoliths from the Bakony-Balaton Highland Volcanic Field (Western Hungary). Contrib Mineral Petrol, 155, 165-79. 
[47] Kovács, I., Falus, G., Stuart, G., Hidas, K., Szabó, C., Flower, M. F. J., et al. (2012). Seismic anisotropy and deformation patterns in upper mantle xenoliths from the central Carpathian-Pannonian region: Asthenospheric flow as a driving force for Cenozoic extension and extrusion? Tectonophysics, 514-517, 168-79.

[48] Yang, K., Hidas, K., Falus, G., Szabó, C., Nam, B., Kovács, I., et al. (2010). Relation between mantle shear zone deformation and metasomatism in spinel peridotite xenoliths of Jeju Island (South Korea): Evidence from olivine CPO and trace elements. J Geodyn, 50(5), 424-40.

[49] Hidas, K., Falus, G., Szabó, C., Szabó, P. J., Kovács, I., \& Földes, T. (2007). Geodynamic implications of flattened tabular equigranular textured peridotites from the Bakony-Balaton Highland Volcanic Field (Western Hungary). J Geodyn, 43, 484-503.

[50] Rubin, A. M. (1995). Propagation of Magma-Filled Cracks. Annual Review Of Earth And Planetary Sciences, 23, 287-336.

[51] Németh, K., \& Cronin, S. J. (2011). Drivers of explosivity and elevated hazard in basaltic fissure eruptions: The 1913 eruption of Ambrym Volcano, Vanuatu (SW-Pacific). J Volcanol Geotherm Res, 201(1-4), 194-209.

[52] Kereszturi, G., \& Németh, K. (2011). Shallow-seated controls on the evolution of the Upper Pliocene Kopasz-hegy nested monogenetic volcanic chain in the Western Pannonian Basin, Hungary. Geol Carpath, 62(6), 535-46.

[53] Gaffney, E. S., Damjanac, B., \& Valentine, G. A. (2007). Localization of volcanic activity: 2. Effects of pre-existing structure. Earth Planet Sci Lett, 263, 323-38.

[54] Valentine, G. A., \& Krogh, K. E. C. (2006). Emplacement of shallow dikes and sills beneath a small basaltic volcanic center- The role of pre-existing structure (Paiute Ridge, southern Nevada, USA). Earth Planet Sci Lett, 246(3-4), 217-30.

[55] Kiyosugi, K., Connor, C. B., Wetmore, P. H., Ferwerda, B. P., Germa, A. M., Connor, L. J., et al. (2012). Relationship between dike and volcanic conduit distribution in a highly eroded monogenetic volcanic field: San Rafael, Utah, USA. Geology, 40(8), 695-698.

[56] Lefebvre, N. S., White, J. D. L., \& Kjarsgaard, B. A. (2012). Spatter-dike reveals subterranean magma diversions: Consequences for small multivent basaltic eruptions. Geology, 40(5), 423-6.

[57] Hintz, A. R., \& Valentine, G. A. (2012). Complex plumbing of monogenetic scoria cones: New insights from the Lunar Crater Volcanic Field (Nevada, USA). J Volcanol Geotherm Res, 239-240(0), 19-32.

[58] Sulpizio, R., De Rosa, R., \& Donato, P. (2008). The influence of variable topography on the depositional behaviour of pyroclastic density currents: The examples of the Upper Pollara eruption (Salina Island, southern Italy). J Volcanol Geotherm Res, 175(3), 367-85. 
[59] Kereszturi, G., Csillag, G., Németh, K., Sebe, K., Balogh, K., \& Jáger, V. (2010). Volcanic architecture, eruption mechanism and landform evolution of a Pliocene intracontinental basaltic polycyclic monogenetic volcano from the Bakony-Balaton Highland Volcanic Field, Hungary. Cent Eur J Geosci, 2(3), 362-84.

[60] Valentine, G. A., Krier, D., Perry, F. V., \& Heiken, G. (2005). Scoria cone construction mechanisms, Lathrop Wells volcano, southern Nevada, USA. Geology, 33(8), 629-32.

[61] Risso, C., Németh, K., Combina, A. M., Nullo, F., \& Drosina, M. (2008). The role of phreatomagmatism in a Plio-Pleisotcene high-density scoria cone field: Llancanelo Volcanic Field, Argentina. J Volcanol Geotherm Res, 168, 61-86.

[62] Magill, C., \& Blong, R. (2005). Volcanic risk ranking for Auckland, New Zealand. II: Hazard consequences and risk calculation. Bull Volcanol, 67(4), 340-9.

[63] Connor, L. J., Connor, C. B., Meliksetian, K., \& Savov, I. (2012). Probabilistic approach to modeling lava flow inundation: a lava flow hazard assessment for a nuclear facility in Armenia. Journal of Applied Volcanology, 1, 3, http:// www.appliedvolc.com/1//3.

[64] Harris, A. J. L., Favalli, M., Wright, R., \& Garbeil, H. (2011). Hazard assessment at Mount Etna using a hybrid lava flow inundation model and satellite-based land classification. Nat Hazards, 58(3), 1001-27.

[65] Németh, K., \& Cronin, S. J. (2009). Phreatomagmatic volcanic hazards where rift-systems meet the sea, a study from Ambae Island, Vanuatu. J Volcanol Geotherm Res, 180(2-4), 246-258.

[66] Cronin, S. J., Bebbington, M., \& Lai, C. D. (2001). A probabilistic assessment of eruption recurrence on Taveuni volcano, Fiji. Bull Volcanol, 63, 274-89.

[67] Siebe, C., Arana-Salinasa, L., \& Abrams, M. (2005). Geology and radiocarbon ages of Tláloc, Tlacotenco, Cuauhtzin, Hijo del Cuauhtzin, Teuhtli, and Ocusacayo monogenetic volcanoes in the central part of the Sierra Chichinautzin, México. J Volcanol Geotherm Res, 141, 225-43.

[68] Kereszturi, G., \& Németh, K. (2012). Structural and morphometric irregularities of eroded Pliocene scoria cones at the Bakony-Balaton Highland Volcanic Field, Hungary. Geomorphology, 136(1), 45-58.

[69] Rodriguez-Gonzalez, A., Fernandez-Turiel, J. L., Perez-Torrado, F. J., Aulinas, M., Carracedo, J. C., Gimeno, D., et al. (2011). GIS methods applied to the degradation of monogenetic volcanic fields: A case study of the Holocene volcanism of Gran Canaria (Canary Islands, Spain). Geomorphology, 134(3-4), 249-259.

[70] Dohrenwend, J. C., Wells, S. G., \& Turrin, B. D. (1986). Degradation of Quaternary cinder cones in the Cima volcanic field, Mojave Desert, California. Geol Soc Am Bull, 97(4), 421-7. 
[71] Wood, C. A. (1980). Morphometric analysis of cinder cone degradation. J Volcanol Geotherm Res, 8(2-4), 137-60.

[72] Németh, K. (2004). Calculation of long-term erosion in Central Otago, New Zealand, based on erosional remnants of maar/tuff rings. Z Geomorphol, 47(1), 29-49.

[73] Büchner, J., \& Tietz, O. (2012). Reconstruction of the Landeskrone Scoria Cone in the Lusatian Volcanic Field, Eastern Germany- Long-term degradation of volcanic edifices and implications for landscape evolution. Geomorphology, 151-152, 175-187.

[74] Németh, K., \& Martin, U. (1999). Late Miocene paleo-geomorphology of the BakonyBalaton Highland Volcanic Field (Hungary) using physical volcanology data. Zeitschrift fr Geomorphologie, 43(4), 417-38.

[75] Lister, J. R., \& Kerr, R. C. (1991). Fluid-Mechanical Models of Crack Propagation and Their Application to Magma Transport in Dykes. J Geophys Res, 96(B6), 10049-77.

[76] O'Neill, C., \& Spiegelman, M. (2010). Formulations for Simulating the Multiscale Physics of Magma Ascent. Dosseto A, Turner SP, van Orman JA, editors. Timescales of Magmatic Processes: From Core to Atmosphere. Chichester, UK. : John Wiley E Sons, Ltd, 87-101.

[77] Gardine, M., West, M., \& Cox, T. (2011). Dike emplacement near Parícutin volcano, Mexico in 2006. Bulletin of Volcanology, 73(2), 123-32.

[78] de la Cruz-Reyna, S., \& Yokoyama, I. (2011). A geophysical characterization of monogenetic volcanism. Geofisica Internacional, 50(4), 465-84.

[79] Németh, K. (2010). Volcanic glass textures, shape characteristics and compositions of phreatomagmatic rock units from the Western Hungarian monogenetic volcanic fields and their implications for magma fragmentation. Cent Eur J Geosci, 2(3), 399-419.

[80] Houghton, B. F., Wilson, C. J. N., Rosenberg, M. D., Smith, I. E. M., \& Parker, R. J. (1996). Mixed deposits of complex magmatic and phreatomagmatic volcanism: an example from Crater Hill, Auckland, New Zealand. Bull Volcanol, 58, 59-66.

[81] Lorenz, V. (2007). Syn- and posteruptive hazards of maar-diatreme volcanoes. J Volcanol Geotherm Res, 159, 285-312.

[82] Gutmann, J. T. (2002). Strombolian and effusive activity as precursors to phreatomagmatism: eruptive sequence at maars of the Pinacate volcanic fields, Sonora, Mexico. J Volcanol Geotherm Res, 113(1-2), 345-56.

[83] Foshag, W. F., \& Gonzalez, J. R. (1956). Birth and development of Paricutin volcano, Mexico Geological Survey Bulletin. 965-D, 355-487.

[84] Wood, C. A. (1980). Morphometric evolution of cinder cones. J Volcanol Geotherm Res, 7(3-4), 387-413. 
[85] Davey, F. J. (2010). Crustal seismic reflection measurements across the northern extension of the Taupo Volcanic Zone, North Island, New Zealand. J Volcanol Geotherm Res, 190(1-2), 75-81.

[86] Wilson, C. J. N., Houghton, B. F., Mc Williams, M. O., Lanphere, M. A., Weaver, S. D., \& Briggs, R. M. (1995). Volcanic and structural evolution of Taupo Volcanic Zone, New Zealand: a review. J Volcanol Geotherm Res, 68(1-3), 1-28.

[87] Houghton, B. F., Wilson, C. J. N., Mc Williams, M. O., Lanphere, MA, Weaver, S. D., Briggs, R. M., et al. (1995). Chronology and dynamics of a large silicic magmatic system: Central Taupo Volcanic Zone, New Zealand. Geology, 23, 13-6.

[88] Wallace, L. M., Beavan, J., Mc Caffrey, R., \& Darby, D. (2004). Subduction zone coupling and tectonic block rotations in the North Island, New Zealand. J Geophys Res, 109(B12), B12406. 10.1029/2004jb003241.

[89] Seghedi, I., \& Downes, H. (2011). Geochemistry and tectonic development of Cenozoic magmatism in the Carpathian-Pannonian region. Gondwana Res, 20, 655-72.

[90] Lexa, J., Seghedi, I., Németh, K., Szakács, A., Konečný, V., Pécskay, Z., et al. (2010). Neogene-Quaternary Volcanic forms in the Carpathian-Pannonian Region: a review. Cent Eur J Geosci, 2(3), 207-70.

[91] Pécskay, Z., Lexa, J., Szakács, A., Seghedi, I., Balogh, K., Konecny, V., et al. (2006). Geochronlogy of Neogene magmatism in the Carpathian arc and intra-Carpathian area. Geol Carpath, 57(6), 511-30.

[92] Harangi, S., \& Lenkey, L. (2007). Genesis of the Neogene to Quaternary volcanism in the Carpathian-Pannonian region: Role of subduction, extension, and mantle plume. Beccaluva L, Bianchini G, Wilson M, editors. Cenozoic Volcanism in the Mediterranean Area. London: Geological Society of America, 67-92.

[93] Szabó, C., Falus, G., Zajacz, Z., Kovács, I., \& Bali, E. (2004). Composition and evolution of lithosphere beneath the Carpathian-Pannonian region: a review. Tectonophysics, 393(1-4), 119-37.

[94] Müller, R. D., Sdrolias, M., Gaina, C., \& Roest, W. R. (2008). Age, spreading rates and spreading symmetry of the world's ocean crust. Geochem Geophys Geosyst, 9(Q04006).

[95] Katz, R. F., Spiegelman, M., \& Holtzman, B. (2006). The dynamics of melt and shear localization in partially molten aggregates. Nature, 442, 676-9.

[96] Courtillot, V., Davaille, A., Besse, J., \& Stock, J. (2006). Three distinct types of hotspots in the Earth's mantle. Earth Planet Sci Lett, 205, 295-308.

[97] King, S. D., \& Anderson, D. L. (1998). Edge-driven convection. Earth Planet Sci Lett, 160, 289-96.

[98] Ballmer, MD, Ito, G., van Hunen, J., \& Tackley, P. J. (2011). Spatial and temporal variability in Hawaiian hotspot volcanism induced by small-scale convection. Nat Geosci, 4, 457-60. 
[99] Ballmer, M. D., van Hunen, J., Ito, G., Tackley, P. J., \& Bianco, T. A. (2007). Non-hotspot volcano chains originating from small-scale sublithospheric convection. Geophysical Rerearch Letters, 43(L23310), 10.1029/2007GL031636.

[100] King, S. D., \& Ritsema, J. (2000). African Hot Spot Volcanism: Small-Scale Convection in the Upper Mantle Beneath Cratons. Science, 290, 1137-40.

[101] Foulger, G. R., \& Natland, J. H. (2003). Is "Hotspot" Volcanism a Consequence of Plate Tectonics? Science, 300, 921-2.

[102] King, D. S., Zimmerman, M. E., \& Kohlstedt, D. L. (2010). Stress-driven Melt Segregation in Partially Molten Olivine-rich Rocks Deformed in Torsion. J Petrol, 51(1-2), 21-42.

[103] Holtzman, B. K., Groebner, N. J., Zimmerman, M. E., Ginsberg, S. B., \& Kohlstedt, D. L. (2003). Stress-driven melt segregation in partially molten rocks. Geochem Geophys Geosyst, 4(5), 8607.

[104] Mc Kenzie, D. (1984). The Generation and Compaction of Partially Molten Rock. J Petrol, 25(3), 713-65.

[105] Laporte, D., \& Watson, E. B. (1995). Experimental and theoretical constraints on melt distribution in crustal sources: the effect of crystalline anisotropy on melt interconnectivity. Chem Geol, 124(3-4), 161-184.

[106] Kelemen, P. B., Hirth, G., Shimizu, N., Spiegelman, M., \& Dick, H. J. (1997). A review of melt migration processes in the adiabatically upwelling mantle beneath oceanic spreading ridges. Philosophical Transactions of the Royal Society A: Mathematical Physical $\mathcal{E}$ Engineering Sciences, 355(1723), 283-318.

[107] Sleep, N. H. (1988). Tapping of Melt by Veins and Dikes. J Geophys Res, 93(B9), 10255-72.

[108] Valentine, G. A., \& Perry, F. V. (2006). Decreasing magmatic footprints of individual volcanoes in a waning basaltic field. Geophys Res Lett, 33(L14305), 10.1029/2006GL026743.

[109] Takada, A. (1994). The influence of regional stress and magmatic input on styles of monogenetic and polygenetic volcanism. J Geophys Res, 99(B7), 10.1029/94JB00494.

[110] Ito, G., \& Martel, S. J. (2002). Focusing of magma in the upper mantle through dike interaction. J Geophys Res, 107(B10), 10.1029/2001JB000251.

[111] Valentine, G. A., \& Gregg, T. K. P. (2008). Continental basaltic volcanoes- Processes and problems. J Volcanol Geotherm Res, 177(4), 857-73.

[112] Dahm, T. (2000). On the shape and velocity of fluid-filled fractures in the Earth. Geophys J Int, 142(1), 181-92. 
[113] Delaney, P. T., Pollard, D. D., Ziony, J. I., \& Mc Kee, E. H. (1986). Field Relations Between Dikes and Joints: Emplacement Processes and Paleostress Analysis. J Geophys Res, 91(B5), 4920-38.

[114] Mazzarini, F., \& D'Orazio, M. (2003). Spatial distribution of cones and satellite-detected lineaments in the Pali Aike Volcanic Field (southernmost Patagonia): insights into the tectonic settings of a Neogene rift system. J Volcanol Geotherm Res, 125, 291-305.

[115] Lara, L. E., Lavenu, A., Cembrano, J., \& Rodríguez, C. (2006). Structural controls of volcanism in transversal chains: Resheared faults and neotectonics in the Cordón Caulle-Puyehue area (40.5 S), Southern Andes. J Vol canol Geotherm Res, 158(1-2), 70.

[116] Walker, G. P. L. (2000). Basaltic volcanoes and volcanic systems. Sigurdsson H, Houghton BF, McNutt SR, Rymer H, Stix J, editors. Encyclopedia of Volcanoes. San Diego: Academic Press, 283-290.

[117] Zernack, A. V., Procter, J. N., \& Cronin, S. J. (2009). Sedimentary signatures of cyclic growth and destruction of stratovolcanoes: A case study from Mt. Taranaki, New Zealand. Sediment Geol, 220, 288-305.

[118] Carracedo, J. C., Rodríguez, Badiola. E., Guillou, H., Paterne, M., Scaillet, S., Pérez Torrado, F. J., et al. (2007). Eruptive and structural history of Teide Volcano and rift zones of Tenerife, Canary Islands. Geol Soc Am Bull, 119(9), 1027-51.

[119] Grosse, P., van Wyk de Vries, B., Petrinovic, I. A., Euillades, P. A., \& Alvarado, G. E. (2009). Morphometry and evolution of arc volcanoes. Geology, 37(7), 651-4.

[120] Buck, R. W., Einarsson, P., \& Brandsdóttir, B. (2006). Tectonic stress and magma chamber size as controls on dike propagation: Constraints from the 1975-1984 Krafla rifting episode. J Geophys Res, 111(B12404), 10.1029/2005JB003879.

[121] Marsh, B. D. (1989). Magma Chambers. Annual Review of Earth and Planetary Sciences, $17,439-74$.

[122] Burov, E., Jaupart, C., \& Guillou-Frottier, L. (2003). Ascent and emplacement of buoyant magma bodies in brittle-ductile upper crust. J Geophys Res, 108(2177), 10.1029/2002JB001904.

[123] Hawkesworth, C. J., Blake, S., Evans, P., Hughes, R., Macdonald, R., Thomas, L. E., et al. (2000). Time scales of crystal fractionation in magma chambers- Integrating physical, isotopic and geochemical perspectives. J Petrol, 41(7), 991-1006.

[124] Alaniz-Alvarez, S. A., Nieto-Samaniego, A. F., \& Ferrari, L. (1998). Effect of strain rate in the distribution of monogenetic and polygenetic volcanism in the Transmexican volcanic belt. Geology, 26(7), 591-4.

[125] Fedotov, S. (1981). Magma rates in feeding conduits of different volcanic centres. J Volcanol Geotherm Res, 9(4), 379-94. 
[126] Suter, M., Contreras, J., Gómez-Tuena, A., Siebe, C., Quintero-Legorreta, O., GarcíaPalomo, A., et al. (1999). Effect of strain rate in the distribution of monogenetic and polygenetic volcanism in the Transmexican volcanic belt: Comments and Reply. Geology, 27(6), 571-5.

[127] Mattsson, H., \& Höskuldsson, Á. (2003). Geology of the Heimaey volcanic centre, south Iceland: early evolution of a central volcano in a propagating rift? J Volcanol Geotherm Res, 127(1-2), 55.

[128] Mc Gee, L. E., Beier, C., Smith, I. E. M., \& Turner, S. P. (2011). Dynamics of melting beneath a small-scale basaltic system: a U-Th-Ra study from Rangitoto volcano, Auckland volcanic field, New Zealand. Contrib Mineral Petrol, 162(3), 547-63.

[129] Kiyosugi, K., Connor, C. B., Zhao, D., Connor, L. J., \& Tanaka, K. (2010). Relationships between volcano distribution, crustal structure, and P-wave tomography: an example from the Abu Monogenetic Volcano Group, SW Japan. Bull Volcanol, 72(3), 331-40.

[130] Toprak, V. (1998). Vent distribution and its relation to regional tectonics, Cappadocian Volcanics, Turkey. J Volcanol Geotherm Res, 85(1-4), 55.

[131] Bacon, C. R. (1982). Time-predictable bimodal volcanism in the Coso Range, California. Geology, 10(2), 65-9.

[132] Frey, H. M., Lange, R. A., Hall, C. M., \& Delgado-Granados, H. (2004). Magma eruption rates constrained by 40Ar/39Ar chronology and GIS for the Ceboruco-San Pedro volcanic field, western Mexico. Geol Soc Am Bull, 116(3-4), 259.

[133] Nakamura, K. (1977). Volcanoes as possible indicators of tectonic stress orientationprincipal and proposal. J Volcanol Geotherm Res, 2(1), 1-16.

[134] Kuntz, M. A., Champion, D. E., Spiker, E. C., \& Lefebvre, R. H. (1986). Contrasting magma types and steady-state, volume-predictable, basaltic volcanism along the Great Rift, Idaho. Geol Soc Am Bull, 97(5), 579-94.

[135] King-Y, C. (1989). Volume predictability of historical eruptions at Kilauea and Mauna Loa volcanoes. J Volcanol Geotherm Res, 38, 281-5.

[136] Parsons, T., \& Thompson, G. A. (1991). The role of magma overpressure in suppressing earthquakes and topography: worldwide examples. Science, 253(5026), 1399-402.

[137] Ebinger, C. J., Keir, D., Ayele, A., Calais, E., Wright, T. J., Belachew, M., et al. (2008). Capturing magma intrusion and faulting processes during continental rupture: seismicity of the Dabbahu (Afar) rift. Geophys J Int, 174(3), 1138-52.

[138] Gudmundsson, A., \& Loetveit, I. F. (2005). Dyke emplacement in a layered and faulted rift zone. J Volcanol Geotherm Res, 144(1-4), 311.

[139] Bebbington, M. (2008). Incorporating the eruptive history in a stochastic model for volcanic eruptions. J Volcanol Geotherm Res, 175, 325-33. 
[140] Aranda-Gómez, J. J., Luhr, J. F., Housh, T. B., Connor, C. B., Becker, T., \& Henry, C. D. (2003). Synextensional Pliocene-Pleistocene eruptive activity in the Camargo volcanic field, Chihuahua, México. Geol Soc Am Bull, 115(3), 298-313.

[141] Guilbaud-N, M., Siebe, C., Layer, P., Salinas, S., Castro-Govea, R., Garduño-Monroy, V. H., et al. (2011). Geology, geochronology, and tectonic setting of the Jorullo Volcano region, Michoacán, México. J Volcanol Geotherm Res, 201(1-4), 97-112.

[142] Wijbrans, J., Németh, K., Martin, U., \& Balogh, K. (2007). 40Ar/39Ar geochronology of Neogene phreatomagmatic volcanism in the western Pannonian Basin, Hungary. $J$ Volcanol Geotherm Res, 164(4), 193-204.

[143] Connor, C. B. (1990). Cinder Cone Clustering in the TransMexican Volcanic Belt: Implications for Structural and Petrologic Models. J Geophys Res, 95(B12), 19, 395-19, 405.

[144] Hasenaka, T., \& Carmichael, I. S. E. (1987). The Cinder Cones of Michoacán-Guanajuato, Central Mexico: Petrology and Chemistry. J Petrol, 28(2), 241-69.

[145] Huang, Y., Hawkesworth, C., van Calsteren, P., Smith, I., \& Black, P. (1997). Melt generation models for the Auckland volcanic field, New Zealand: constraints from U-Th isotopes. Earth Planet Sci Lett, 149.

[146] Putirka, K. D., Kuntz, MA, Unruh, D. M., \& Vaid, N. (2009). Magma Evolution and Ascent at the Craters of the Moon and Neighboring Volcanic Fields, Southern Idaho, USA: Implications for the Evolution of Polygenetic and Monogenetic Volcanic Fields. J Petrol, 50(9), 1639-65.

[147] Austin-Erickson, A., Ort, M. H., \& Carrasco-Núñez, G. (2011). Rhyolitic phreatomagmatism explored: Tepexitl tuff ring (Eastern Mexican volcanic belt). J Volcanol Geotherm Res, 201(1-4), 325-41.

[148] Brooker, M. R., Houghton, B. F., Wilson, C. J. N., \& Gamble, J. A. (1993). Pyroclastic phases of a rhyolitic dome-building eruption: Puketarata tuff ring, Taupo Volcanic Zone, New Zealand. Bull Volcanol, 55(6), 395-406.

[149] Walker, G. P. L. (1973). Explosive volcanic eruptions- a new classification scheme. Geol Rundsch, 62(2), 431-46.

[150] Parfitt, E. A. (2004). A discussion of the mechanisms of explosive basaltic eruptions. J Volcanol Geotherm Res, 134(1-2), 77-107.

[151] Wohletz, K. H. (1986). Explosive magma-water interactions: Thermodynamics, explosion mechanism and field studies. Bull Volcanol, 48(5), 245-64.

[152] Lorenz, V. (1985). Maars and diatremes of phreatomagmatic origin: a review. S Afr J Geol, 88(2), 459-70.

[153] Vergniolle, S., Brandeis, G., \& Mareschal-C, J. (1996). Strombolian explosions: Eruption dynamics determined from acoustic measurements. J Geophys Res, 101, 20449-66. 
[154] Parfitt, E. A., \& Wilson, L. (1995). Explosive volcanic eruptions- IX. The transition between Hawaiian-style lava fountaining and Strombolian explosive activity. Geophys J Int, 121(1), 226-32.

[155] Blackburn, E. A., \& Sparks, R. S. J. (1976). Mechanism and dynamics of Strombolian activity. J Geol Soc, 132, 429-40.

[156] Pioli, L., Azzopardi, B. J., \& Cashman, K. V. (2009). Controls on the explosivity of scoria cone eruptions: Magma segregation at conduit junctions. J Volcanol Geotherm Res, 186(3-4), 407-415.

[157] Johnson, E., Wallace, P., Chashman, K., Granados, H. D., \& Kent, A. (2008). Magmatic volatile contents and degassing-induced crystallization at Volcán Jorullo, Mexico: Implications for melt evolution and the plumbing systems of monogenetic volcanoes. Earth Planet Sci Lett, 269, 478-87.

[158] Walker, G. P. L., \& Croasdale, R. (1972). Characteristics of some basaltic pyroclastics. Bull Volcanol, 35(2), 303-17.

[159] Houghton, B. F., \& Gonnermann, H. M. (2008). Basaltic explosive volcanism: Constraints from deposits and models. Chem Erde, 68, 117-40.

[160] Wilson, L., \& Head, J. W. (1981). Ascent and eruption of basaltic magma on the Earth and Moon. J Geophys Res, 86, 2971-3001.

[161] Sparks, R. S. J. (1978). The dynamics of bubble formation and growth in magmas: A review and analysis. J Volcanol Geotherm Res, 3(1-2), 1-37.

[162] Parfitt, E. A. (1998). A study of clast size distribution, ash deposition and fragmentation in a Hawaiian-style volcanic eruption. J Volcanol Geotherm Res, 84, 197-208.

[163] Pioli, L., Erlund, E., Johnson, E., Cashman, N. K., Wallace, P., Rosi, M., et al. (2008). Explosive dynamics of violent Strombolian eruptions: The eruption of Parícutin Volcano 1943-1952 (Mexico). Earth Planet Sci Lett, 271(1-4), 359-68.

[164] Coltelli, M., Del Carlo, P., \& Vezzoli, L. (1998). Discovery of a Plinian basaltic eruption of Roman age at Etna volcano, Italy. Geology, 26(12), 1095-8.

[165] Houghton, B. F., Wilson, C. J. N., Del Carlo, P., Coltelli, M., Sable, J. E., \& Carey, R. (2004). The influence of conduit processes on changes in style of basaltic Plinian eruptions: Tarawera 1886 and Etna 122 BC. J Volcanol Geotherm Res, 137, 1-14.

[166] Vergniolle, S., \& Mangan, M. T. (2000). Hawaiian and Strombolian eruptions. Sigurdsson H, Houghton B, McNutt SR, Rymer H, Stix J, editors. Encyclopedia of VolcanoesSan Diego: Academic Press, 447-461.

[167] Stovall, W. K., Houghton, B. F., Gonnermann, H., Fagents, S. A., \& Swanson, D. A. (2011). Eruption dynamics of Hawaiian-style fountains: the case study of episode 1 of the Kilauea Iki 1959 eruption. Bull Volcanol, 73(5), 511-29. 
[168] Polacci, M., Corsaro, R. A., \& Andronico, D. (2006). Coupled textural and compositional characterization of basaltic scoria: Insights into the transition from Strombolian to fire fountain activity at Mount Etna Italy. Geology, 34(3), 201-4.

[169] Duffield, W. A., Christiansen, R. L., Koyanagi, R., \& Peterson, D. W. (1982). Storage, migration, and eruption of magma at Kilauea volcano, Hawaii, 1971-1972. J Volcanol Geotherm Res, 13, 273-307.

[170] Head, J. W., \& Wilson, L. (1987). Lava fountain heights at Pu'u'O'o, Kilauea, Hawaii: Indicators of amount and variations of exsolved magma volatiles. J Geophys Res, 92(B13), 13715.

[171] Sumner, J., Blake, S., Matela, R., \& Wolff, J. (2005). Spatter. J Volcanol Geotherm Res, $142,49-65$.

[172] Head, J. W., \& Wilson, L. (1989). Basaltic pyroclastic eruptions: Influence of gas-release patterns and volume fluxes on fountain structure, and the formation of cinder cones, spatter cones, rootless flows, lava ponds and lava flows. J Volcanol Geotherm Res, 37(3-4), 261-271.

[173] Heliker, C., Kauahikaua, J., Sherrod, D. R., Lisowski, M., \& Cervelli, P. F. (2003). The Rise and Fall of $\mathrm{Pu}^{\prime} \mathrm{u}^{\prime} \mathrm{O}$ 'ö Cone, 1983-2002. US Geological Survey Professional Paper $1676,29-52$.

[174] Wolff, J. A., \& Sumner, J. M. (2000). Lava fountains and their products. Sigurdsson H, Houghton BF, McNutt SR, Rymer H, Stix J, editors. Encyclopedia of Volcanoes. San Diego: Academic Press, 321-329.

[175] Capaccioni, B., \& Cuccoli, F. (2005). Spatter and welded air fall deposits generated by fire-fountaining eruptions : Cooling of pyroclasts during transport and deposition. $J$ Volcanol Geotherm Res, 145(3-4), 263 -280.

[176] Parfitt, E. A., \& Wilson, L. (1999). A Plinian treatment of fallout from Hawaiian lava fountains. J Volcanol Geotherm Res, 88(1-2), 67-75.

[177] Head, J. W., Bryan, W. B., Greeley, R., Guest, J. E., Schultz, P. H., Sparks, R. S. J., et al. (1981). Distribution and morphology of basalt deposits on planets. Project BVS, editors. Basaltic Volcanism on the Terrestrial Planets. New York: Pergamon Press, 701-800.

[178] Kauahikaua, J., Sherrod, D. R., Cashman, K. V., Heliker, C., Hon, K., Mattox, T. N., et al. (2003). Hawaiian Lava-Flow Dynamics During the $\mathrm{Pu}^{\prime} \mathrm{u}$ 'Ö'ö-Küpaianaha Eruption: A Tale of Two Decades. US Geological Survey Professional Paper 1676, 63-88.

[179] Wood, C. A. (1979). Monogenetic volcanoes in terrestrial planets. Proceedings of the 10th Lunar and Planetary Science Conference.

[180] Patrick, M. R., Harris, A. J. L., Ripepe, M., Dehn, J., Rothery, D. A., \& Calvari, S. (2007). Strombolian explosive styles and source conditions: insights from thermal (FLIR) video. Bull Volcanol, 69, 769-84. 
[181] Vespermann, D., \& Schmincke-U, H. (2000). Scoria cones and tuff rings. Sigurdsson H, Houghton BF, McNutt SR, Rymer H, Stix J, editors. Encyclopedia of VolcanoesSan Diego: Academic Press, 683-694.

[182] Riedel, C., Ernst, G. G. J., \& Riley, M. (2003). Controls on the growth and geometry of pyroclastic constructs. J Volcanol Geotherm Res, 127(1-2), 121-52.

[183] Harris, A. J. L., Ripepe, M., \& Hughes, E. A. (2012). Detailed analysis of particle launch velocities, size distributions and gas densities during normal explosions at Stromboli. J Volcanol Geotherm Res, 132, 109-131.

[184] Calvari, S., \& Pinkerton, H. (2004). Birth, growth and morphologic evolution of the'Laghetto' cinder cone during the 2001 Etna eruption. J Volcanol Geotherm Res, 132, 225-39.

[185] Mc Getchin, T. R., Settle, M., \& Chouet, BA. (1974). Cinder cone growth modeled after Northeast Crater, Mount Etna, Sicily. J Geophys Res, 79, 3257-72.

[186] Houghton, B. F., \& Wilson, C. J. N. (1989). A vesicularity index for pyroclastic deposits. Bull Volcanol, 51(6), 451-62.

[187] Mangan, M. T., \& Cashman, K. V. (1996). The structure of basaltic scoria and reticulite and inferences for vesiculation, foam formation, and fragmentation in lava fountains. J Volcanol Geotherm Res, 73, 1-18.

[188] Valentine, G. A., Krier, D. J., Perry, F. V., \& Heiken, G. (2007). Eruptive and geomorphic processes at the Lathrop Wells scoria cone volcano. J Volcanol Geotherm Res, 161(1-2), 57.

[189] Settle, M. (1979). The structure and emplacement of cinder cone fields. Am J Sci, 279(10), 1089-107.

[190] Mac, Donald. G. A. (1972). Volcanoes. Englewood Cliffs: Prentice-Hall.

[191] Erlund, E. J., Cashman, K. V., Wallace, P. J., Pioli, L., Rosi, M., Johnson, E., et al. (2010). Compositional evolution of magma from Parícutin Volcano, Mexico: The tephra record. J Volcanol Geotherm Res, 197(1-4), 167-87.

[192] Zimanowski, B., \& Büttner, R. (2002). Dynamic mingling of magma and liquefied sediments. J Volcanol Geotherm Res, 114, 37-44.

[193] Zimanowski, B., Büttner, R., \& Lorenz, V. (1997). Premixing of magma and water in MFCI experiments. Bull Volcanol, 58(6), 491-5.

[194] White, J. D. L. (1996). Impure coolants and interaction dynamics of phreatomagmatic eruptions. J Volcanol Geotherm Res, 74(3-4), 155-70.

[195] Németh, K., Goth, K., Martin, U., Csillag, G., \& Suhr, P. (2008). Reconstructing paleoenvironment, eruption mechanism and paleomorphology of the Pliocene Pula maar, (Hungary). J Volcanol Geotherm Res, 177(2), 441-56. 
[196] Kokelaar, P. (1986). Magma-water interactions in subaqueous and emergent basaltic volcanism. Bull Volcanol, 48, 275-89.

[197] Zimanowski, B., \& Wohletz, K. H. (2000). Physics of phreatomagmatism I. Terra Nostra, 6, 515-23.

[198] Lorenz, V., \& Kurszlaukis, S. (2007). Root zone processes in the phreatomagmatic pipe emplacement model and consequences for the evolution of maar-diatreme volcanoes. J Volcanol Geotherm Res, 159, 4-32.

[199] Lorenz, V. (1986). On the growth of maar and diatremes and its relevance to the formation of tuff rings. Bull Volcanol, 48(5), 265-74.

[200] White, J. D. L., \& Ross-S, P. (2011). Maar-diatreme volcanoes: A review. J Volcanol Geotherm Res, 201(1-4), 1-29.

[201] Büttner, R., Dellino, P., \& Zimanowski, B. (1999). Identifying modes of magma/water interaction from the surface features of ash particles. Nature, 401, 688-90.

[202] Sottili, G., Palladino, D., Gaeta, M., \& Masotta, M. (2012). Origins and energetics of maar volcanoes: examples from the ultrapotassic Sabatini Volcanic District (Roman Province, Central Italy). Bull Volcanol, 74(1), 163-86.

[203] Mattox, T. N., \& Mangan, M. T. (1997). Littoral hydrovolcanic explosions: a case study of lava-seawater interaction at Kilauea volcano. J Volcanol Geotherm Res, 75(1-2), $1-17$.

[204] Jurado-Chichay, Z., Rowland, S. K., \& Walker, G. P. L. (1996). The formation of circular littoral cone from tube-fed pahoehoe: Mauna Loa, Hawaii. Bull Volcanol, 57(7), 471-82.

[205] Thorarinsson, S. (1953). The crater groups in Iceland. Bull Volcanol, 14, 3-44.

[206] Hamilton, C. W., Thordarson, T., \& Fagents, S. A. (2010). Explosive lava-water interactions I: architecture and emplacement chronology of volcanic rootless cone groups in the 1783-1784 Laki lava flow, Iceland. Bull Volcanol, 72, 449-67.

[207] Hamilton, C. W., Fagents, S. A., \& Thordarson, T. (2010). Explosive lava-water interactions II: self-organization processes among volcanic rootless eruption sites in the 1783-1784 Laki lava flow, Iceland. Bull Volcanol, 72, 469-85.

[208] Fagents, S. A., \& Thordarson, T. (2007). Rootless volcanic cones in Iceland and on Mars. Chapman MG, editors. The geology of Mars: evidence from Earth-based analogs.New York, USA: Cambridge University Press, 151-177.

[209] Lorenz, V. (2003). Maar-Diatreme Volcanoes, their Formation, and their Setting in Hard-rock or Soft-rock environments. Geolines, 15, 72-83.

[210] Mattsson, H. B., \& Tripoli, B. A. (2011). Depositional characteristics and volcanic landforms in the Lake Natron-Engaruka monogenetic field, northern Tanzania. J Volcanol Geotherm Res, 203, 23-34. 
[211] Stoppa, F., Rosatelli, G., Schiazza, M., \& Tranquilli, A. (2012). Hydrovolcanic vs Magmatic Processes in Forming Maars and Associated Pyroclasts: The Calatrava-SpainCase History. Stoppa F, editors. Updates in Volcanology- A Comprehensive Approach to Volcanological Problems. InTech, 3-26, http://www.intechopen.com/books/updates-involcanology-a-comprehensive-approach-to-volcanological-problems/hydrovolcanicvs-magmatic-processes-in-forming-maars-and-associated-pyroclasts-the-calatravaspain-c.

[212] Stoppa, F. (1996). The San Venanzo maar and tuff ring, Umbria, Italy: eruptive behaviour of a carbonatite-melilitite volcano. Bull Volcanol, 57(7), 563-77.

[213] Lorenz, V., Mc Birney, A. R., \& Williams, H. (1970). An investigation of volcanic depressions. Part III. Maars, tuff-rings, tuff-cones, and diatremes. Houston, Texas.

[214] Blaikie, T. N., Ailleres, L., Cas, R. A. F., \& Betts, P. G. (2012). Three-dimensional potential field modelling of a multi-vent maar-diatreme- The Lake Coragulac maar, Newer Volcanics Province, southeastern Australia. I Volcanol Geotherm Res, 235-236(0), 70-83.

[215] Beget, J. E., Hopkins, D. M., \& Charron, S. D. (1996). Largest known maars (Espenberg Maars) on earth, Seward Peninsula, northwest Alaska. Arctic, 49(1), 62-9.

[216] Grunewald, U., Zimanowski, B., Büttner, R., Phillips, L. F., Heide, K., \& Büchel, G. (2007). MFCI experiments on the influence of NaCl-saturated water on phreatomagmatic explosions. J Volcanol Geotherm Res, 159(1-3), 126.

[217] Sheridan, M. F., \& Wohletz, K. H. (1981). Hydrovolcanic Explosions: The Systematics of Water-Pyroclast Equilibration. Science, 212, 1387-9.

[218] Wohletz, K. H., \& Valentine, G. A. (1990). Computer simulations of explosive volcanic eruptions. Ryan MP, editors. Magma transport and storage, 114-134.

[219] Büttner, R., Dellino, P., La Volpe, L., Lorenz, V., \& Zimanowski, B. (2002). Thermohydraulic explosions in phreatomagmatic eruptions as evidenced by the comparison between pyroclasts and products from Molten Fuel Coolant Interaction experiments. J Geophys Res, 107(B11), 10.1029/2001JB000511.

[220] Büttner, R., \& Zimanowski, B. (1998). Physics of thermohydraulic explosions. Physical Review E, 57(5), 5726-9.

[221] Wohletz, K. H., \& Mc Queen, R. G. (1984). Experimental Studies of Hydrovolcanic Explosions. editors. Explosive volcanism: Inception, evolution and hazards. Washington D.C., USA: National Academy Press, 158-169.

[222] Kokelaar, B. P. (1983). The mechanism of Surtseyan volcanism. J Geol Soc, 140, 939-44.

[223] Wohletz, K. H., \& Sheridan, M. F. (1983). Hydrovolcanic explosions II. Evolution of basaltic tuff rings and tuff cones. Am J Sci, 283, 385-413. 
[224] Gençalioğlu-Kuşcu, G., Atilla, C., Cas, R. A. F., \& Ilkay, K. (2007). Base surge deposits, eruption history, and depositional processes of a wet phreatomagmatic volcano in Central Anatolia (Cora Maar). J Volcanol Geotherm Res, 159(1-3), 198-209.

[225] Funiciello, R., Giordano, G., \& De Rita, D. (2003). The Albano maar lake (Colli Albani Volcano, Italy): recent volcanic activity and evidence of pre-Roman Age catastrophic lahar events. J. Volcanol Geotherm Res, 123, 43-61.

[226] Vazquez, J. A., \& Ort, M. H. (2006). Facies variation of eruption units produced by the passage of single pyroclastic surge currents, Hopi Buttes volcanic field, USA. J Volcanol Geotherm Res, 154(3-4), 222-36.

[227] Sulpizio, R., \& Dellino, P. (2008). Chapter 2 Sedimentology, Depositional Mechanisms and Pulsating Behaviour of Pyroclastic Density Currents. Joachim G, Joan M, iacute, editors. Developments in Volcanology. Elsevier., 57-96.

[228] Carrasco-Núñez, G., Ort, M. H., \& Romero, C. (2007). Evolution and hydrological conditions of a maar volcano (Atexcac crater, Eastern Mexico). J Volcanol Geotherm Res, 159, 179-97.

[229] Auer, A., Martin, U., \& Németh, K. (2007). The Fekete-hegy (Balaton Highland Hungary) „soft-substrate” and "hard-substrate” maar volcanoes in an aligned volcanic complex- Implications for vent geometry, subsurface stratigraphy and the paleoenvironmental setting. J Volcanol Geotherm Res, 159(1-3), 225-45.

[230] Pardo, N., Macias, J. L., Giordano, G., Cianfarra, P., Avellán, D. R., \& Bellatreccia, F. (2009). The $\sim 1245$ yr BP Asososca maar eruption: The youngest event along the Nejapa-Miraflores volcanic fault, Western Managua, Nicaragua. J Volcanol Geotherm Res, 184(3-4), 292-312.

[231] Raue, H. (2004). A new model for the fracture energy budget of phreatomagmatic explosions. J Volcanol Geotherm Res, 129(1-3), 99.

[232] White, J. D. L., \& Schmincke-U, H. (1999). Phreatomagmatic eruptive and depositional processes during the ' 49 eruption on La Palma (Canary Islands). J Volcanol Geotherm Res, 94(1-4), 283-304.

[233] Martin, U., \& Németh, K. (2005). Eruptive and depositional history of a Pliocene tuff ring hat developed in a fluvio-lacustrine basin: Kissomlyó volcano (western Hungary). J Volcanol Geotherm Res, 147, 342-56.

[234] Sohn, Y. K. (1996). Hydrovolcanic processes forming basaltic tuff rings and cones on Cheju Island, Korea. Geol Soc Am Bull, 108(10), 1199-211.

[235] Chough, S. K., \& Sohn, Y. K. (1990). Depositional mechanics and sequences of base surges, Songaksan tuff ring, Cheju Island, Korea. Sedimentology, 37, 1115-35.

[236] Aranda-Gómez, J. J., \& Luhr, J. F. (1996). Origin of the Joya Honda maar, San Luis Potosí, Mexico. J Volcanol Geotherm Res, 74, 1-18. 
[237] Lorenz, V. (1974). Vesiculated tuffs and associated features. Sedimentology, 21(2), 273-91.

[238] Alvarado, G. E., Soto, G. J., Salani, F. M., Ruiz, P., \& de Mendoza, L. H. (2011). The formation and evolution of Hule and Río Cuarto maars, Costa Rica. J Volcanol Geotherm Res, 201(1-4), 342-356.

[239] Ngwa, C. N., Suh, C. E., \& Devey, C. W. (2010). Phreatomagmatic deposits and stratigraphic reconstruction at Debunscha Maar (Mt Cameroon volcano). J Volcanol Geotherm Res, 192(3-4), 201-11.

[240] Dellino, P., Isaia, R., La Volpe, L., \& Orsi, G. (2004). Interaction between particles transported by fallout and surge in the deposits of the Agnano-Monte Spina eruption (Campi Flegrei, Southern Italy). J Volcanol Geotherm Res, 133(1-4), 193-210.

[241] Németh, K., \& White, C. M. (2009). Intra-vent peperites related to the phreatomagmatic 71 Gulch Volcano, western Snake River Plain volcanic field, Idaho (USA). J Volcanol Geotherm Res, 183(1-2), 30-41.

[242] Hetényi, G., Taisne, B., Garel, F., Médard, É., Bosshard, S., \& Mattsson, H. (2012). Scales of columnar jointing in igneous rocks: field measurements and controlling factors. Bull Volcanol, 74(2), 457-82.

[243] Martí, J., Planagumà, L., Geyer, A., Canal, E., \& Pedrazzi, D. (2011). Complex interaction between Strombolian and phreatomagmatic eruptions in the Quaternary monogenetic volcanism of the Catalan Volcanic Zone (NE of Spain). J Volcanol Geotherm Res, 201(1-4), 178-93.

[244] Aranda-Gómez, J. J., Luhr, J. F., \& Pier, G. (1992). The La Brena- El Jagüey Maar Complex, Durango, México: I. Geological evolution. Bull Volcanol, 54(5), 393-404.

[245] Lorenz, V. (2003). Syn- and post-eruptive processes of maar-diatreme volcanoes and their relevance to the accumulation of port-eruptive maar creater sediments. Földtani Kutatás, 11(1-2), 13-22.

[246] Molloy, C., Shane, P., \& Augustinus, P. (2009). Eruption recurrence rates in a basaltic volcanic field based on tephra layers in maar sediments: Implications for hazards in the Auckland volcanic field. Geol Soc Am Bull, 121(11-12), 1666-77.

[247] Pirrung, M., Fischer, C., Büchel, G., Gaupp, R., Lutz, H., \& Neuffer-O, F. (2003). Lithofacies succession of maar crater deposits in the Eifel area (Germany). Terra Nova, 15(2), 125-32.

[248] Németh, K. (2001). Deltaic density currents and turbidity deposits related to maar crater rims and their importance for paleogeographic reconstructionof the BakonyBalaton Highland Volcanic Field, Hungary. Kneller B, McCaffrey B, Peakall J, Druitt T, editors. Sediment transport and deposition by particulate gravity currents. Oxford: Blackwell Sciences, 261-277. 
[249] Pastre-F, J., Gauthier, A., Nomade, S., Orth, P., Andrieu, A., Goupille, F., et al. (2007). The Alleret maar (Massif Central, France): A new lacustrine sequence of the early Middle Pleistocene in western Europe. CR Geosci, 339, 987-97.

[250] Zolitschka, B. (1993). Palaeoecological implications from the sedimentary record of a subtropical maar lake (Eocene Eckfelder Maar; Germany). Negendank JW, Zolitschka B, editors. Paleolimnology of European Maar Lakes. Springer Berlin Heidelberg, 477-484.

[251] Lorenz, V. (1974). Studies of the Surtsey tephra deposits. Surtsey Research Progress Report VII, 72-9.

[252] Kano, K. (1998). A shallow-marine alkali-basalt tuff cone in the Middle Miocene Jinzai Formation, Izumo, SW Japan. J Volcanol Geotherm Res, 87(1-4), 173.

[253] White, J. D. L. (2000). Subaqueous eruption-fed density currents and their deposits. Precambrian Res, 101(2-4), 87-109.

[254] White, J. D. L. (1996). Pre-emergent construction of a lacustrine basaltic volcano, Pahvant Butte, Utah (USA). Bull Volcanol, 58(4), 249-62.

[255] Cas, R. A. F., Landis, C. A., \& Fordyce, R. E. (1989). A monogenetic, Surtla-type, Surtseyan volcano from the Eocene-Oligocene Waiareka-Deborah volcanics, Otago, New Zealand: A model. Bulletin of Volcanology, 51(4), 281-98.

[256] Martin, U., Breitkreuz, C., Egenhoff, S., Enos, P., \& Jansa, L. (2004). Shallow-marine phreatomagmatic eruptions through a semi-solidified carbonate platform (ODP Leg 144, Site 878, Early Cretaceous, MIT Guyot, West Pacific). Mar Geol, 204(3-4), 251.

[257] Garvin, J. B., Williams, R. S., Frawley, J. J., \& Krabill, W. B. (2000). Volumetric evolution of Surtsey, Iceland, from topographic maps and scanning airborne laser altimetry. Surtsey Research, 11, 127-34.

[258] Vaughan, R. G., \& Webley, P. W. (2010). Satellite observations of a surtseyan eruption: Hunga Ha'apai, Tonga. J Volcanol Geotherm Res, 198(1-2), 177-86.

[259] Zanon, V., Pachecoa, J., \& Pimentel, A. (2009). Growth and evolution of an emergent tuff cone: Considerations from structural geology, geomorphology and facies analysis of São Roque volcano, São Miguel (Azores). J Volcanol Geotherm Res, 180(2-4), 277-291.

[260] Kokelaar, B. P., \& Durant, G. P. (1983). The submarine eruption and erosion of Surtla (Surtsey), Iceland. J Volcanol Geotherm Res, 19(3-4), 239-46.

[261] Thorarinsson, S. (1965). Surtsey eruption course of events and the developement of the new island. Surtsey Research Progress Report I, 51-5.

[262] Mattsson, H. B. (2010). Textural variation in juvenile pyroclasts from an emergent, Surtseyan-type, volcanic eruption: The Capelas tuff cone, São Miguel (Azores). J Volcanol Geotherm Res, 189(1-2), 81-91. 
[263] Németh, K., Cronin, S. J., Charley, D., Harrison, M., \& Garae, E. (2006). Exploding lakes in Vanuatu- "Surtseyan-style" eruption witnessed on Ambae Island. Episodes, 29(2), 87-92.

[264] Brand, B. D., \& Clarke, A. B. (2009). The architecture, eruptive history, and evolution of the Table Rock Complex, Oregon: From a Surtseyan to an energetic maar eruption. J Volcanol Geotherm Res, 180(2-4), 203-24.

[265] Sohn, Y. K., \& Chough, S. K. (1993). The Udo tuff cone, Cheju Island, South Korea: transformation of pyroclastic fall into debris fall and grain flow on a steep volcanic cone slope. Sedimentology, 40, 769-86.

[266] Mattsson, H. B., Höskuldsson, A., \& Hand, S. (2005). Crustal xenoliths in the 6220 BP Saefell tuff-cone, south Iceland: Evidence for a deep, diatreme-forming, Surtseyan eruption. J Volcanol Geotherm Res, 145(3-4), 234-248.

[267] Suiting, I., \& Schmincke-U, H. (2009). Internal vs. external forcing in shallow marine diatreme formation: A case study from the Iblean Mountains (SE-Sicily, Central Mediterranean). J Volcanol Geotherm Res, 186(3-4), 361-378.

[268] Martin, U., \& Németh, K. (2004). Mio/Pliocene Phreatomagmatic Volcanism in the Western Pannonian Basin. Budapest.

[269] Cassidy, J., France, S. J., \& Locke, CA. (2007). Gravity and magnetic investigation of maar volcanoes, Auckland volcanic field, New Zealand. J Volcanol Geotherm Res, 159(1-3), 153.

[270] Weinstein, Y. (2007). A transition from strombolian to phreatomagmatic activity induced by a lava flow damming water in a valley. J Volcanol Geotherm Res, 159, 267-84.

[271] Alvarado, G. E., Soto, G. J., Salani, F. M., Ruiz, P., \& de Mendoza, L. H. (2011). The formation and evolution of Hule and Río Cuarto maars, Costa Rica. Journal of Volcanology and Geothermal Research, 201(1-4), 342-356.

[272] Luhr, J. F. (2001). Glass inclusions and melt volatile contents at Paricutin Volcano, Mexico. Contrib Mineral Petrol, 142(3), 261-83.

[273] Németh, K., Risso, C., Nullo, F., \& Kereszturi, G. (2011). The role of collapsing and rafting of scoria cones on eruption style changes and final cone morphology: Los Morados scoria cone, Mendoza Argentina. Cent Eur J Geosci, 3(2), 102-18.

[274] Needham, A. J., Lindsay, J. M., Smith, I. E. M., Augustinus, P., \& Shane, P. A. (2011). Sequential Eruption of Alkaline and Sub-Alkaline Magmas from a small Monogenetic volcano in The Auckland Volcanic Field, New Zealand. J Volcanol Geotherm Res, 201(1-4), 126-42.

[275] Cervantes, P., \& Wallace, P. (2003). Magma degassing and basaltic eruption styles: a case study of 2000 year BP Xitle volcano in central Mexico. J Volcanol Geotherm Res, 120(3-4), 249-70. 
[276] Johnson, E. R., Wallace, P. J., Cashman, K. V., \& Delgado, Granados. H. (2010). Degassing of volatiles $(\mathrm{H} 2 \mathrm{O}, \mathrm{CO} 2, \mathrm{~S}, \mathrm{Cl})$ during ascent, crystallization, and eruption of basaltic magmas. J Volcanol Geotherm Res, 197(1-4), 225-38.

[277] Houghton, B. F., \& Schmincke-U, H. (1986). Mixed deposits of simultaneous strombolian and phreatomagmatic volcanism: Rothenberg volcano, East Eifel Volcanic Field. J Volcanol Geotherm Res, 30, 117-30.

[278] Sohn, Y. K., \& Park, K. H. (2005). Composite tuff ring/cone complexes in Jeju Island, Korea: possible consequences of substrate collapse and vent migration. J Volcanol Geotherm Res, 141, 157-75.

[279] Ort, M. H., \& Carrasco-Núñez, G. (2009). Lateral vent migration during phreatomagmatic and magmatic eruptions at Tecuitlapa Maar, east-central Mexico. J Volcanol Geotherm Res, 181(1-2), 67-77.

[280] Bishop, M. A. (2009). A generic classification for the morphological and spatial complexity of volcanic (and other) landforms. Geomorphology, 111(1-2), 104-9.

[281] Walker, G. (1971). Compound and simple lava flows and flood basalts. Bull Volcanol, 35(3), 579-90.

[282] Németh, K. (2004). The morphology and origin of wide craters at Al Haruj al Abyad, Libya: maars and phreatomagmatism in a large intracontinental flood lava field? $\mathrm{Z}$ Geomorphol, 48(4), 417-39.

[283] Solgevik, H., Mattsson, H., \& Hennelin, O. (2007). Growth of an emergent tuff cone: Fragmentation and depositional processes recorded in the Capelas tuff cone, São Miguel, Azores. J Volcanol Geotherm Res, 159, 246-66.

[284] Gutmann, J. T. (1976). Geology of Crater Elegante, Sonora, Mexico. Geol Soc Am Bull, $87(12), 1718-29$.

[285] Ross-S, P., \& White, J. D. L. (2006). Debris jets in continental phreatomagmatic volcanoes: a field study of their subterranean deposits in the Coombs Hills vent complex, Antarctica. J Volcanol Geotherm Res, 149, 62-84.

[286] Sohn, Y. K., Cronin, S. J., Brenna, M., Smith, I. E. M., Németh, K., White, J. D. L., et al. (2012). Ilchulbong tuff cone, Jeju Island, Korea, revisited: A compound monogenetic volcano involving multiple magma pulses, shifting vents, and discrete eruptive phases. Geol Soc Am Bull, 10.1130/B30447.1.

[287] Shaw, C., \& Woodland, A. (2012). The role of magma mixing in the petrogenesis of mafic alkaline lavas, Rockeskyllerkopf Volcanic Complex, West Eifel, Germany. Bull Volcanol, 74(2), 359-76.

[288] Martin, U., \& Németh, K. (2006). How Strombolian is a "Strombolian" scoria cone? Some irregularities in scoria cone architecture from the Transmexican Volcanic Belt, near Volcán Ceboruco (Mexico), and Al Haruj (Libya). J Volcanol Geotherm Res, 155(1-2), 104-118. 
[289] Karátson, D. (1996). Rates and factors of stratovolcano degradation in a continental climate: a complex morphometric analysis for nineteen Neogene/Quaternary crater remnants in the Carpathians. J Volcanol Geotherm Res, 73(1-2), 65.

[290] Inbar, M., Gilichinsky, M., Melekestsev, I., Melnikov, D., \& Zaretskaya, N. (2011). Morphometric and morphological development of Holocene cinder cones: A field and remote sensing study in the Tolbachik volcanic field, Kamchatka. J Volcanol Geotherm Res, 201(1-4), 301-311.

[291] Rodriguez-Gonzalez, A., Fernandez-Turiel, J. L., Perez-Torrado, F. J., Gimeno, D., \& Aulinas, M. (2009). Geomorphological reconstruction and morphometric modelling applied to past volcanism. Int J Earth Sci, 99(3), 645-60.

[292] Karátson, D., Telbisz, T., \& Wörner, G. (2012). Erosion rates and erosion patterns of Neogene to Quaternary stratovolcanoes in the Western Cordillera of the Central Andes: An SRTM DEM based analysis. Geomorphology, 139-140, 122-135.

[293] Pike, R. J. (1978). Volcanoes on the inner planets: Some preliminary comparisons of gross topography. Proceedings of the 10th Lunar and Planetary Science Conference, 3, 3239-73.

[294] Karátson, D., Favalli, M., Tarquini, S., Fornaciai, A., \& Wörner, G. (2010). The regular shape of stratovolcanoes: A DEM-based morphometrical approach. J Volcanol Geotherm Res, 193(3-4), 171-181.

[295] Grosse, P., van Wyk de Vries, B., Euillades, P. A., Kervyn, M., \& Petrinovic, I. (2012). Systematic morphometric characterization of volcanic edifices using digital elevation models. Geomorphology, 136, 114-31.

[296] Procter, J. N., Cronin, S. J., Platz, T., Patra, A., Dalbey, K., Sheridan, M., et al. (2010). Mapping block-and-ash flow hazards based on Titan 2D simulations: a case study from Mt. Taranaki, NZ. Nat Hazards, 53, 483-501.

[297] Procter, J., Cronin, S. J., Fuller, I. C., Lube, G., \& Manville, V. (2010). Quantifying the geomorphic impacts of a lake-breakout lahar, Mount Ruapehu, New Zealand. Geolo$g y, 38(1), 67-70$.

[298] Tibaldi, A. (1995). Morphology of pyroclastic cones and tectonics. J Geophys Res, 100(B12), 24521-35.

[299] Inbar, M., \& Risso, C. (2001). A morphological and morphometric analysis of a high density cinder cone volcanic field.- Payun Matru, south-central Andes, Argentina. Z Geomorphol, 45(3), 321-43.

[300] Colton, H. S. (1937). The basaltic cinder cones and lava flows of the San Francisco Mountain Volcanic Field. Museum of Northern Arizona Bulletin, 10, 1-58.

[301] Porter, S. C. (1972). Distribution, Morphology, and Size Frequency of Cinder Cones on Mauna Kea Volcano, Hawaii. Geol Soc Am Bull, 83(12), 3607-12. 
[302] Moriya, I. (1986). Morphometry of Pyroclastic Cones in Japan. The geographical reports of Kanazawa University, 3, 58-76.

[303] Hasenaka, T., \& Carmichael, I. S. E. (1985). A compilation of location, size, and geomophological parameters of volcanoes of the Michoacan-Guanajuato volcanic field, central Mexico. Geofisica Internacional, 24(4), 577-607.

[304] Hasenaka, T., \& Carmichael, I. S. E. (1985). The cinder cones of Michoacán-Guanajuato central Mexico: their age, volume and distribution, and magma discharge rate. J Volcanol Geotherm Res, 25(1-2), 105-24.

[305] Bleacher, J. E., Glaze, L. S., Greeley, R., Hauber, E., Baloga, S. M., Sakimoto, S. E. H., et al. (2009). Spatial and alignment analyses for a field of small volcanic vents south of Pavonis Mons and implications for the Tharsis province, Mars. J Volcanol Geotherm Res, 185, 96-102.

[306] Mest, S. C., \& Crown, D. A. (2005). Millochau crater, Mars: Infilling and erosion of an ancient highland impact crater. Icarus, 175, 335-59.

[307] Glaze, L. S., Anderson, S. W., Stofan, E. R., \& Smrekar, S. E. (2005). Statistical distribution of tumuli on pahoehoe flow surfaces: analysis of examples in Hawaii and Iceland and potential applications to lava flows on Mars. J Geophys Res, 110(B08202), 10.1029/2004JB003564.

[308] Armstrong, J. C., \& Leovy, C. B. (2005). Long term wind erosion on Mars. Icarus, 176, 57-74.

[309] Pike, R. J. (1976). Crater dimensions from Apollo data and supplemental sources. The Moon, 15, 463-77.

[310] Pike, R. J. (1977). Apparent depth/apparent diameter relation for lunar craters. Proceedings of the 8th Lunar Science Conference, 3, 3427-36.

[311] Ghent, R. R., Anderson, S. W., \& Pithawala, T. M. (2012). The formation of small cones in Isidis Planitia, Mars through mobilization of pyroclastic surge deposits. Icarus, 217(1), 169-83.

[312] Bemis, K., Walker, J., Borgia, A., Turrin, B., Neri, M., \& Swisher, III C. (2011). The growth and erosion of cinder cones in Guatemala and El Salvador: models and statistics. J Volcanol Geotherm Res, 201(1-4), 39-52.

[313] Sato, H., \& Taniguchi, H. (1997). Relationship between crater size and ejecta volume of recent magmatic and phreato-magmatic eruptions: Implications for energy partitioning. Geophys Res Lett, 24(3), 205-8.

[314] Kervyn, M., Ernst, G. G. J., Carracedo-C, J., \& Jacobs, P. (2012). Geomorphometric variability of "monogenetic" volcanic cones: Evidence from Mauna Kea, Lanzarote and experimental cones. Geomorphology, 136(1), 59-75. 
[315] Corazzato, C., \& Tibaldi, A. (2006). Fracture control on type, morphology and distribution of parasitic volcanic cones: an example from Mt. Etna, Italy. J Volcanol Geotherm Res, 158(1-2), 177-94.

[316] Tibaldi, A. (2003). Influence of cone morphology on dykes, Stromboli, Italy. J Volcanol Geotherm Res, 126(1-2), 79-95.

[317] Favalli, M., Karátson, D., Mazzarini, F., Pareschi, M. T., \& Boschi, E. (2009). Morphometry of scoria cones located on a volcano flank: A case study from Mt. Etna (Italy), based on high-resolution LiDAR data. J Volcanol Geotherm Res, 186(3-4), 320-30.

[318] Conway, F. M., Connor, C. B., Hill, B. E., Condit, C. D., Mullaney, K., \& Hall, C. M. (1998). Recurrence rates of basaltic volcanism in SP cluster, San Francisco volcanic field, Arizona. Geology, 26(7), 655-8.

[319] Rodríguez, S. R., Morales-Barrera, W., Layer, P., \& González-Mercado, E. (2010). A quaternary monogenetic volcanic field in the Xalapa region, eastern Trans-Mexican volcanic belt: Geology, distribution and morphology of the volcanic vents. J Volcanol Geotherm Res, 197(1-4), 149-66.

[320] Aguirre-Díaz, G. J., Jaimes-Viera, M. C., \& Nieto-Obregón, J. (2006). The Valle de Bravo Volcanic Field: Geology and geomorphometric parameters of a Quaternary monogenetic field at the front of the Mexican Volcanic Belt. Geological Society of America Special Papers, 402, 139-54.

[321] Dóniz, J., Romero, C., Carmona, J., \& García, A. (2011). Erosion of cinder cones in Tenerife by gully formation, Canary Islands, Spain. Physical Geography, 32(2), 139-60.

[322] Doniz, J., Romero, C., Coello, E., Guillen, C., Sanchez, N., Garcia-Cacho, L., et al. (2008). Morphological and statistical characterisation of recent mafic volcanism on Tenerife (Canary Islands, Spain). J Volcanol Geotherm Res, 173(3-4), 185-95.

[323] Hooper, D. M. (1999). Cinder movement experiments on scoria cone slopes: Rates and direction of transport. Landform Analysis, 2, 5-18.

[324] Hooper, D. M., \& Sheridan, M. F. (1998). Computer-simulation models of scoria cone degradation. J Volcanol Geotherm Res, 83(3-4), 241-67.

[325] Hooper, D. M. (1995). Computer-simulation models of scoria cone degradation in the Colima and Michoacán-Guanajuato volcanic fields, Mexico. Geofisica Internacional, 34(3), 321-40.

[326] Fornaciai, A., Behncke, B., Favalli, M., Neri, M., Tarquini, S., \& Boschi, E. (2011). Detecting short-term evolution of Etnean scoria cones: a LIDAR-based approach. Bull Volcanol, 72(10), 1209-22.

[327] Pelletier, J. D., \& Cline, M. L. (2007). Nonlinear slope-dependent sediment transport in cinder cone evolution. Geology, 35(12), 1067-70.

[328] Thouret-C, J. (1999). Volcanic geomorphology- an overview. Earth-Science Reviews, 47, 95-131. 
[329] Karátson, D., Telbisz, T., \& Singer, BS. (2010). Late-stage volcano geomorphic evolution of the Pleistocene San Francisco Mountain, Arizona (USA), based on high-resolution DEM analysis and 40Ar/39Ar chronology. Bull Volcanol, 72(7), 833-46.

[330] Székely, B., \& Karátson, D. (2004). DEM-based morpometry as a tool for reconstructing primary volcanic landforms: examples from the Börzsöny Mountains, Hungary. Geomorphology, 63, 25-37.

[331] Lahitte, P., Samper, A., \& Quidelleur, X. (2012). DEM-based reconstruction of southern Basse-Terre volcanoes (Guadeloupe archipelago, FWI): Contribution to the Lesser Antilles Arc construction rates and magma production. Geomorphology, 136(1), 148-64.

[332] Csatho, B., Schenk, T., Kyle, P., Wilson, T., \& Krabill, W. B. (2008). Airborne laser swath mapping of the summit of Erebus volcano, Antarctica: Applications to geological mapping of a volcano. J Volcanol Geotherm Res, 177(3), 531-48.

[333] Parrot-F, J. (2007). Study of Volcanic Cinder Cone Evolution by Means of High Resolution DEMs. MODSIM 2007 International Congress on Modelling and Simulation; 2007: Modelling and Simulation Society of Australia and New Zealand.

[334] Parrot-F, J. (2007). Tri-dimensional parameterisation: an automated treatment to study the evolution of volcanic cones. Géomorphologie: relief, processus, environnement, 2007(3), 247-57.

[335] Awdankiewicz, M. (2005). Reconstructing an eroded scoria cone: the Miocene Sosnica Hill volcano (Lower Silesia, SW Poland). Geological Quarterly, 49, 439-48.

[336] Rapprich, V., Cajz, V., Kostak, M., Pécskay, Z., Ridkosil, T., Raska, P., et al. (2007). Reconstruction of eroded monogenetic Strombolian cones of Miocene age: A case study on character of volcanic activity of the Jicin Volcanic Field (NE Bohemia) and subsequent erosional rates estimation. Journal of Geoscience, 52(3-4), 169-80.

[337] Fornaciai, A., Behncke, B., Favalli, M., Neri, M., Tarquini, S., \& Boschi, E. (2012). Morphometry of scoria cones, and their relation to geodynamic setting: A DEMbased analysis. J Volcanol Geotherm Res, 217-218, 56-72.

[338] Kereszturi, G., Geyer, A., Martí, J., Németh, K., \& Dóniz-Páez, J. F. (in press) Evaluation of morphometry-based dating of monogenetic volcanoes - A case study from Bandas del Sur, Tenerife (Canary Islands). Bull Volcanol.

[339] Lanz, J. K., Wagner, R., Wolf, U., Kröchert, J., \& Neukum, G. (2010). Rift zone volcanism and associated cinder cone field in Utopia Planitia, Mars. J Geophys Res, 115(E12), E12019.

[340] Pike, R. J. (1974). Craters on Earth, Moon, and Mars: Multivariate classification and mode of origin. Earth Planet Sci Lett, 22(3), 245-55.

[341] Frey, H., \& Jarosewich, M. (1982). Subkilometer Martian Volcanoes: Properties and Possible Terrestrial Analogs. J Geophys Res, 87(B12), 9867-79. 
[342] Avellán, D. R., Macías, J. L., Pardo, N., Scolamacchia, T., \& Rodriguez, D. (2012). Stratigraphy, geomorphology, geochemistry and hazard implications of the Nejapa Volcanic Field, western Managua, Nicaragua. J Volcanol Geotherm Res, 213-214, 51-71.

[343] Taddeucci, J., Sottili, G., Palladino, D. M., Ventura, G., \& Scarlato, P. (2009). A note on maar eruption energetics: current models and their application. Bull Volcanol, 72(1), 75-83.

[344] Goto, A., Taniguchi, H., Yoshida, M., Ohba, T., \& Oshima, H. (2001). Effects of explosion energy and depth to the formation of blast wave and crater: Field Explosion Experiment for the understanding of volcanic explosion. Geophys Res Lett, 28(22), 4287-90.

[345] Martín-Serrano, A., Vegas, J., García-Cortés, A., Galán, L., Gallardo-Millán, J. L., Martín-Alfageme, S., et al. (2009). Morphotectonic setting of maar lakes in the Campo de Calatrava Volcanic Field (Central Spain, SW Europe). Sediment Geol, 222(1-2), 52-63.

[346] Valentine, G. A., Shufelt, N. L., \& Hintz, A. R. L. (2011). Models of maar volcanoes, Lunar Crater (Nevada, USA). Bull Volcanol, 73(6), 753-65.

[347] Valentine, G. A. (2012). Shallow plumbing systems for small-volume basaltic volcanoes, 2: Evidence from crustal xenoliths at scoria cones and maars. J Volcanol Geotherm Res, 223-224, 47-63.

[348] Zimanowski, B. (1998). Phreatomagmatic explosions. Freundt A, Rosi M, editors. From Magma to Tephra: Developments in Volcanology 4. Amsterdam: Elsevier, 25-54.

[349] Leat, P. T., \& Thompson, R. N. (1988). Miocene hydrovolcanism in NW Colorado, USA, fuelled by explosive mixing of basic magma and wet unconsolidated sediment. Bull Volcanol, 50(4), 229-43.

[350] Mc Clintock, M., \& White, J. (2006). Large phreatomagmatic vent complex at Coombs Hills, Antarctica: Wet, explosive initiation of flood basalt volcanism in the Ferrar-Karoo LIP. Bull Volcanol, 68(3), 215-39.

[351] Hearn, B. C. (1968). Diatremes with Kimberlitic Affinities in North-Central Montana. Science, 159(3815), 622-5.

[352] Yokoo, A., Taniguchi, H., Goto, A., \& Oshima, H. (2002). Energy and depth of Usu 2000 phreatic explosions. Geophys Res Lett, 29(24), 10.1029/2002GL015928.

[353] Nordyke, M. D. (1962). An Analysis of Cratering Data from Desert Alluvium. J Geophys Res, 67(5), 1965-74.

[354] Chabai, A. J. (1965). On Scaling Dimensions of Craters Produced by Buried Explosives. J Geophys Res, 70(20), 5075-98.

[355] Ross-S, P., Delpit, S., Haller, MJ, Németh, K., \& Corbella, H. (2011). Influence of the substrate on maar-diatreme volcanoes- an example of a mixed setting from the Pali Aike volcanic field, Argentina. J Volcanol Geotherm Res, 201(1-4), 253-71. 
[356] Jankowski, D. G., \& Squyres, S. W. (1992). The Topography of Impact Craters in "Softened" Terrain. Icarus, 100, 26-39.

[357] Self, S., Kienle, J., \& Hout-P, J. (1980). Ukinrek maar, Alaska, II Deposits and formation of the 1977 craters. J Volcanol Geotherm Res, 7, 39-65.

[358] Kienle, J., Kyle, P. R., Self, S., Motyka, R. J., \& Lorenz, V. (1980). Ukinrek maar, Alaska, I April 1977 Eruption sequence, petrology and tectonic setting. J Volcanol Geotherm Res, 7, 11-37.

[359] Geshi, N., Németh, K., \& Oikawa, T. (2011). Growth of phreatomagmatic explosion craters: A model inferred from Suoana crater in Miyakejima Volcano, Japan. J Volcanol Geotherm Res, 201(1-4), 30-8.

[360] Sparks, R. S. J., Baker, L., Brown, R. J., Field, M., Schumacher, J., Stripp, G., et al. (2006). Dynamical constraints on kimberlite volcanism. J Volcanol Geotherm Res, 155(1-2), 18-48.

[361] Walters, A. L., Phillips, J. C., Brown, R. J., Field, M., Gernon, T., Stripp, G., et al. (2006). The role of fluidisation in the formation of volcaniclastic kimberlite: Grain size observations and experimental investigation. J Volcanol Geotherm Res, 155(1-2), 119-37.

[362] Allen, S. R., \& Smith, I. E. M. (1994). Eruption styles and volcanic hazard in the Auckland Volcanic Field, New Zealand. Geoscience Reports of Shizuoka University, 20, 5-14.

[363] Kereszturi, G., Németh, K., Cronin, J. S., Smith, I. E. M., Agustin-Flores, J., Lindsay, J., (in preparation). Eruptive magmatic volumes of the Quaternary Auckland Volcanic Field (New Zealand).

[364] Rout, D. J., Cassidy, J., Locke, CA, \& Smith, I. E. M. (1993). Geophysical evidence for temporal and structural relationships within the monogenetic basalt volcanoes of the Auckland volcanic field, northern New Zealand. J Volcanol Geotherm Res, 57(1-2), 71-83.

[365] Murtagh, R. M., White, J. D. L., \& Sohn, Y. K. (2011). Pyroclast textures of the Ilchulbong 'wet' tuff cone, Jeju Island, South Korea. J Volcanol Geotherm Res, 201(1-4), 385-96.

[366] Cole, P. D., Guest, J. E., Duncan, A. M., \& Pacheco-M, J. (2001). Capelinhos 1957-1958, Faial, Azores: deposits formed by an emergent surtseyan eruption. Bull Volcanol, 63(2-3), 204-20.

[367] Luhr, J. F., \& Simkin, T. (1993). Parícutin: the volcano born in a Mexican cornfield. Geoscience Press.

[368] Mannen, K., \& Ito, T. (2007). Formation of scoria cone during explosive eruption at Izu-Oshima volcano, Japan. Geophys Res Lett, 34(L18302), 10.1029/2007GL030874.

[369] Gutmann, J. T. (1979). Structure and eruptive cycle of cinder cones in the Pinacate volcanic field and controls of strombolian activity. J Geol, 87, 448-54. 
[370] Ripepe, M., \& Harris, A. J. L. (2008). Dynamics of the 5 April 2003 explosive paroxysm observed at Stromboli by a near-vent thermal, seismic and infrasonic array. Geophys Res Lett, 35(7).

[371] Chouet, B., Hamisevicz, N., \& Mc Getchin, T. R. (1974). Photoballistics of Volcanic Jet Activity at Stromboli, Italy. J Geophys Res, 79(32), 4961-76.

[372] Ripepe, M., Rossi, M., \& Saccorotti, G. (1993). Image processing of explosive activity at Stromboli. J Volcanol Geotherm Res, 54(3-4), 335-51.

[373] Taddeucci, J., Scarlato, P., Capponi, A., Del Bello, E., Cimarelli, C., Palladino, D. M., et al. (2012). High-speed imaging of Strombolian explosions: The ejection velocity of pyroclasts. Geophys Res Lett, 39(2), L02301, 10.1029/2011GL050404.

[374] Rosi, M., Bertagnini, A., Harris, A. J. L., Pioli, L., Pistolesi, M., \& Ripepe, M. (2006). A case history of paroxysmal explosion at Stromboli: Timing and dynamics of the April 5, 2003 event. Earth Planet Sci Lett, 243, 594-606.

[375] Sable, J., Houghton, B., Wilson, C., \& Carey, R. (2006). Complex proximal sedimentation from Plinian plumes: the example of Tarawera 1886. Bull Volcanol, 69(1), 89-103.

[376] Kervyn, M., Ernst, G., Keller, J., Vaughan, R., Klaudius, J., Pradal, E., et al. (2010). Fundamental changes in the activity of the natrocarbonatite volcano Oldoinyo Lengai, Tanzania. Bull Volcanol, 72(8), 913-31.

[377] Patrick, M. R. (2007). Dynamics of Strombolian ash plumes from thermal video: Motion, morphology, and air entrainment. J Geophys Res, 112(B6), B06202-40, 10.1029/2006JB004387.

[378] Guilbaud-N, M., Siebe, C., \& Agustín-Flores, J. (2009). Eruptive style of the young high-Mg basaltic-andesite Pelagatos scoria cone, southeast of México City. Bull Volcanol, 71(8), 859-880.

[379] Ernst, G. G. J., Sparks, R. S. J., Carey, S. N., \& Bursik, M. I. (1996). Sedimentation from turbulent jets and plumes. J Geophys Res, 101(B3), 5575-89.

[380] Bertotto, G. W., Bjerg, E. A., \& Cingolani, C. A. (2006). Hawaiian and Strombolian style monogenetic volcanism in the extra-Andean domain of central-west Argentina. J Volcanol Geotherm Res, 158(3-4), 430-44.

[381] Van Burkalow, A. (1945). Angle of repose and angle of sliding friction: an experimental study. Geol Soc Am Bull, 56(6), 669-707.

[382] Tokarev, P. (1978). Prediction and characteristics of the 1975 eruption of Tolbachik volcano, Kamchatka. Bull Volcanol, 41(3), 251-8.

[383] Fedotov, S., Enman, V., Nikitenko, Y., Maguskin, M., Levin, V., \& Enman, S. (1980). Crustal deformations related to the formation of new tolbachik volcanoes in 1975-1976, Kamchatka. Bull Volcanol, 43(1), 35-45.

[384] Tokarev, P. I. (1983). Calculation of the magma discharge, growth in the height of the cone and dimensions of the feeder channel of Crater I in the Great Tolbachik Fissure 
Eruption, July 1975. Fedotov SA, Markhinin YK, editors. The Great Tolbachik Fissure Eruption: Geological and Geophysical Data, 1975-1976 Cambridge: Cambridge University Press, 27-35.

[385] Fedotov, S., Chirkov, A., Gusev, N., Kovalev, G., \& Slezin, Y. (1980). The large fissure eruption in the region of Plosky Tolbachik volcano in Kamchatka, 1975-1976. Bull Volcanol, 43(1), 47-60.

[386] Ripepe, M., Ciliberto, S., \& Della Schiava, M. (2001). Time constraints for modeling source dynamics of volcanic explosions at Stromboli. J Geophys Res, 106(B5), 8713-27.

[387] Taddeucci, J., Pompilio, M., \& Scarlato, P. (2004). Conduit processes during the JulyAugust 2001 explosive activity of Mt. Etna (Italy): inferences from glass chemistry and crystal size distribution of ash particles. J Volcanol Geotherm Res, 137(1-3), 33-54.

[388] Self, S., Sparks, R. S. J., Booth, B., \& Walker, G. P. L. (1974). The 1973 Heimaey Strombolian Scoria deposit, Iceland. Geol Mag, 111, 539-48.

[389] Doubik, P., \& Hill, B. E. (1999). Magmatic and hydromagmatic conduit development during the 1975 Tolbachik Eruption, Kamchatka, with implications for hazards assessment at Yucca Mountain, NV. J Volcanol Geotherm Res, 91(1), 43-64.

[390] Holm, R. F. (1987). Significance of agglutinate mounds on lava flows associated with monogenetic cones: An example at Sunset Crater, northern Arizona. Geol Soc Am Bull, 99(3), 319-24.

[391] Valentine, G. A., Perry, F. V., Krier, D., Keating, G. N., Kelley, R. E., \& Cogbil, A. H. (2006). Small-volume basaltic volcanoes: Eruptive products and processes, and posteruptive geomorphic evolution in Crater Flat (Pleistocene), southern Nevada. Geol Soc Am Bull, 118(11-12), 1313-30.

[392] Self, S., Keszthelyi, L., \& Thordarson, T. (1998). The importance of pahoehoe. Annual Review of Earth and Planetary Sciences, 26, 81-110.

[393] Calvari, S., \& Pinkerton, H. (1999). Lava tube morphology on Etna and evidence for lava flow emplacement mechanisms. J Volcanol Geotherm Res, 90(3-4), 263-80.

[394] Inbar, M., Enriquez, A. R., \& Graniel, J. H. G. (2001). Morphological changes and erosion processes following the 1982 eruption of El Chichón volcano, Chiapas, Mexico. Géomorphologie: relief, processus, environnement, 2001(3), 175-83.

[395] Lutz, T. M., \& Gutmann, J. T. (1995). An improved method of determining alignments of point-like features and its implications for the Pinacate volcanic field, Mexico. J Geophys Res, 100(B9), 17659-70.

[396] Paulsen, T. S., \& Wilson, T. J. (2010). New criteria for systematic mapping and reliability assessment of monogenetic volcanic vent alignments and elongate volcanic vents for crustal stress analyses. Tectonophysics, 482(1-4), 16-28. 
[397] Riggs, N. R., \& Duffield, W. A. (2008). Record of complex scoria cone eruptive activity at Red Mountain, Arizona, USA, and implications for monogenetic mafic volcanoes. J Volcanol Geotherm Res, 178, 763-76.

[398] Kereszturi, G., Jordan, G., Németh, K., \& Dóniz-Páez, J. F. (2012). Syn-eruptive morphometric variability of monogenetic scoria cones. Bull Volcanol, 74(9), 2171-2185.

[399] Di Traglia, F., Cimarelli, C., de Rita, D., \& Gimeno, Torrente. D. (2009). Changing eruptive styles in basaltic explosive volcanism: Examples from Croscat complex scoria cone, Garrotxa Volcanic Field (NE Iberain Peninsula). J Volcanol Geotherm Res, 180(2-4), 89-109.

[400] Suhr, P., Goth, K., Lorenz, V., \& Suhr, S. (2006). Long lasting subsidence and deformation in and above maar-diatreme volcanoes- a never ending story. Zeitschrift der Deutschen Gesellschaft für Geowissenschaften, 157(3), 491-511.

[401] Lorenz, V., Suhr, P., \& Goth, K. (2003). Maar-Diatrem-Vulkanismus- Ursachen und Folgen. Die Guttauer Vulkangruppe in Ostsachsen als Beispiel für die komplexen Zusammenhänge. Zeitschrift für Geologische Wissenschaften, 31(4-6), 267-312.

[402] Dessert, C., Dupré, B., Gaillardet, J., François, L. M., \& Allègre, C. J. (2003). Basalt weathering laws and the impact of basalt weathering on the global carbon cycle. Chem Geol, 202(3-4), 257-73.

[403] West, A. J., Galy, A., \& Bickle, M. (2005). Tectonic and climatic controls on silicate weathering. Earth Planet Sci Lett, 235(1-2), 211-28.

[404] Brady, P. V., \& Carroll, S. A. (1994). Direct effects of CO2 and temperature on silicate weathering: Possible implications for climate control. Geochim Cosmochim Acta, 58(7), 1853-6.

[405] Raymo, M. E., \& Ruddiman, W. F. (1992). Tectonic forcing of late Cenozoic climate. Nature, 359(6391), 117-22.

[406] Riebe, C. S., Kirchner, J. W., \& Finkel, R. C. (2004). Erosional and climatic effects on long-term chemical weathering rates in granitic landscapes spanning diverse climate regimes. Earth Planet Sci Lett, 224(3-4), 547-62.

[407] Hinsinger, P., Fernandes, Barros. O. N., Benedetti, M. F., Noack, Y., \& Callot, G. (2001). Plant-induced weathering of a basaltic rock: experimental evidence. Geochim Cosmochim Acta, 65(1), 137-52.

[408] Németh, K., Cronin, S. J., Stewart, R. B., \& Charley, D. (2009). Intra- and extra-caldera volcaniclastic facies and geomorphic characteristics of a frequently active mafic island-arc volcano, Ambrym Island, Vanuatu. Sediment Geol, 220(3-4), 256-70.

[409] Major, J. J., \& Yamakoshi, T. (2005). Decadal-scale change of infiltration characteristics of a tephra-mantled hillslope at Mount St Helens, Washington. Hydrol Processes, 19(18), 3621-30. 
[410] Ferrucci, M., Pertusati, S., Sulpizio, R., Zanchetta, G., Pareschi, M. T., \& Santacroce, R. (2005). Volcaniclastic debris flows at La Fossa Volcano (Vulcano Island, southern Italy): Insights for erosion behaviour of loose pyroclastic material on steep slopes. J Volcanol Geotherm Res, 145(3-4), 173-91.

[411] Segerstrom, K. (1950). Erosion Studies at Paricutin, State of Michoacán, Mexico. Geological Survey Bulletin, 965-A, 1-163.

[412] White, J. D. L. (1991). The depositional record of small, monogenetic volcanoes within terrestrial basins. Fisher EV, Smith GA, editors. Sedimentation in Volcanic Settings, 155-171.

[413] Valentine, G. A., \& Harrington, C. D. (2006). Clast size controls and longevity of Pleistocene desert pavements at Lathrop Wells and Red Cone volcanoes, southern Nevada. Geology, 34(7), 533-6.

[414] Mc Fadden, L. D., Mc Donald, E. V., Wells, S. G., Anderson, K., Quade, J., \& Forman, S. L. (1998). The vesicular layer and carbonate collars of desert soils and pavements: formation, age and relation to climate change. Geomorphology, 24(2-3), 101-45.

[415] Mc Fadden, L. D., Wells, S. G., \& Jercinovich, M. J. (1987). Influences of eolian and pedogenic processes on the origin and evolution of desert pavements. Geology, 15(6), 504-8.

[416] Wells, S. G., Dohrenwend, J. C., Mc Fadden, L. D., Turrin, B. D., \& Mahrer, K. D. (1985). Late Cenozoic landscape evolution on lava flow surfaces of the Cima volcanic field, Mojave Desert, California. Geol Soc Am Bull, 96(12), 1518-29.

[417] Kato, T., Kamijo, T., Hatta, T., Tamura, K., \& Higashi, T. (2005). Initial Soil Formation Processes of Volcanogenous Regosols (Scoriacious) from Miyake-jima Island, Japan. Soil Science \& Plant Nutrition, 51(2), 291-301.

[418] Melo, R., Vieira, G., Caselli, A., \& Ramos, M. (2012). Susceptibility modelling of hummocky terrain distribution using the information value method (Deception Island, Antarctic Peninsula). Geomorphology, 155-156(0), 88-95.

[419] López-Martínez, J., Serrano, E., Schmid, T., Mink, S., \& Linés, C. (2012). Periglacial processes and landforms in the South Shetland Islands (northern Antarctic Peninsula region). Geomorphology, 155-156(0), 62-79.

[420] Kinnell, P. I. A. (2005). Raindrop-impact-induced erosion processes and prediction: a review. Hydrol Processes, 19(14), 2815-44.

[421] Van Dijk, A. I. J. M., Bruijnzeel, L. A., \& Wiegman, S. E. (2003). Measurements of rain splash on bench terraces in a humid tropical steepland environment. Hydrol Processes, 17(3), 513-35.

[422] Dunne, T., Malmon, D. V., \& Mudd, S. M. (2010). A rain splash transport equation assimilating field and laboratory measurements. J Geophys Res, 115(F1), F01001. 
[423] Horton, R. E. (1945). Erosional development of streams and their drainage basins; hydrophysical approach to quantitative morphology. Geol Soc Am Bull, 56(3), 275-370.

[424] Cronin, S. J., \& Neall, V. E. (2001). Holocene volcanic geology, volcanic hazard and risk on Taveuni, Fiji New Zeal. J Geol Geophys, 44, 417-37.

[425] Németh, K., \& Cronin, S. J. (2007). Syn- and post-eruptive erosion, gully formation, and morphological evolution of a tephra ring in tropical climate erupted in 1913 in West Ambrym, Vanuatu. Geomorphology, 86, 115-30.

[426] Poesen, J., Nachtergaele, J., Verstraeten, G., \& Valentin, C. (2003). Gully erosion and environmental change: importance and research needs. Catena, 50(2-4), 91-133.

[427] Matsuoka, N. (2001). Solifluction rates, processes and landforms: a global review. Earth-Science Reviews, 55(1-2), 107-34.

[428] Holness, S. D. (2004). Sediment movement rates and processes on cinder cones in the maritime Subantarctic (Marion Island). Earth Surf Processes Landforms, 29(1), 91-103.

[429] Woodroffe, C. D. (2002). Coasts: Form, Process and Evolution. Cambridge: Cambridge University Press.

[430] Sohn, Y. K., \& Yoon-H, S. (2010). Shallow-marine records of pyroclastic surges and fallouts over water in Jeju Island, Korea, and their stratigraphic implications. Geology, 38(8), 763-6.

[431] Calles, B., Lindé, K., \& Norrman, J. O. (1982). The geomorphology of Surtsey island in 1980. Surtsey Research Progress Report IX, 117-32.

[432] Norrman, J. O., Calles, B., \& Larsson, R. A. (1974). The geomorphology of Surtsey Island in 1972. Surtsey Research Progress Report VII, 61-71.

[433] Sohn, Y. K., Park, K. H., \& Yoon-H, S. (2008). Primary versus secondary and subaerial versus submarine hydrovolcanic deposits in the subsurface of Jeju Island, Korea. Sedimentology, 55(4), 899-924.

[434] Rachold, V., Grigoriev, M. N., Are, F. E., Solomon, S., Reimnitz, E., Kassens, H., et al. (2000). Coastal erosion vs riverine sediment discharge in the Arctic Shelf seas. Int J Earth Sci, 89(3), 450-60.

[435] Arnalds, O., Gisladottir, F. O., \& Orradottir, B. (2012). Determination of aeolian transport rates of volcanic soils in Iceland. Geomorphology, 167-168, 4-12.

[436] Thorarinsdottir, E. F., \& Arnalds, O. (2012). Wind erosion of volcanic materials in the Hekla area, South Iceland. Aeolian Research, 4, 39-50.

[437] Rech, J. A., Reeves, R. W., \& Hendricks, D. M. (2001). The influence of slope aspect on soil weathering processes in the Springerville volcanic field, Arizona. Catena, 43(1), 49-62. 
[438] Dohrenwend, J. C., Mc Fadden, L. D., Turrin, B. D., \& Wells, S. G. (1984). K-Ar dating of the Cima volcanic field, eastern Mojave Desert, California: Late Cenozoic volcanic history and landscape evolution. Geology, 12(3), 163-7.

[439] Rad, S. D., Allègre, C. J., \& Louvat, P. (2007). Hidden erosion on volcanic islands. Earth Planet Sci Lett, 262(1-2), 109-24.

[440] Gaillardet, J., Millot, R., \& Dupré, B. (2003). Chemical denudation rates of the western Canadian orogenic belt: the Stikine terrane. Chem Geol, 201(3-4), 257-79.

[441] Kereszturi, G., Procter, J., Cronin, J. S., Németh, K., Bebbington, M., \& Lindsay, J. (2012). LiDAR-based quantification of lava flow hazard in the City of Auckland (New Zealand). Remote Sens Environ, 125, 198-213.

[442] Oliva, P., Viers, J., \& Dupré, B. (2003). Chemical weathering in granitic environments. Chem Geol, 202(3-4), 225-56.

[443] Ort, M. H., Elson, M. D., Anderson, K. C., Duffield, W. A., \& Samples, T. L. (2008). Variable effects of cinder-cone eruptions on prehistoric agrarian human populations in the American southwest. J Volcanol Geotherm Res, 176(3), 363-76.

[444] Rowland, S. K., Jurado-Chichay, Z., \& Ernst, G. J. (2009). Pyroclastic deposits and lava flows from the 1759-1774 eruption of El Jorullo, México: Aspects of "violent strombolian" activity and comparison with Parícutin. Hoskuldsson A, Thordarson T, Larsen G, Self S, Rowland S, editors. The Legacy of George PL Walker, Special Publications of IAVCEI 2. London, UK: Geological Society of London, 105-128.

[445] Cronin, S. J., Hedley, M. J., Neall, V. E., \& Smith, R. G. (1998). Agronomic impact of tephra fallout from the 1995 and 1996 Ruapehu Volcano eruptions, New Zealand. Environ Geol, 34(1), 21-30.

[446] Grishin, S., \& del Moral, R. (1996). Dynamics of forests after catastrophic eruptions of Kamchatka's volcanoes. Turner IM, Diong CH, Lim SSL, $\mathrm{Ng}$ PKL, editors. Biodiversity and Dynamics of Ecosystems. DIWPA Series, 1, 133-146.

[447] Chinen, T., \& Riviere, A. (1990). Post-eruption erosion processes and plant recovery in the summit atrio of Mt. Usu, Japan. Catena, 17(3), 305-14.

[448] White, J. D. L., Houghton, B. F., Hodgson, K. A., \& Wilson, C. J. N. (1997). Delayed sedimentary response to the A.D. 1886 eruption of Tarawera, New Zealand. Geology, 25(5), 459-62.

[449] Kralj, P. (2011). Eruptive and sedimentary evolution of the Pliocene Grad Volcanic Field, North-east Slovenia. J Volcanol Geotherm Res, 201(1-4), 272-84.

[450] Shaw, S. J., Woodland, A. B., Hopp, J., \& Trenholm, N. D. (2010). Structure and evolution of the Rockeskyllerkopf Volcanic Complex, West Eifel Volcanic Field, Germany. Bull Volcanol, 72, 971-90.

[451] Bullard, F. M. (1947). Studies on Paricutin volcano, Michoacan, Mexico. Geol Soc Am Bull, 58, 433-50. 
[452] Chinen, T. (1986). Surface erosion associated with tephra deposition on Mt. Usu and other volcanoes. Environmental Science, Hokkaido, 9(1), 137-49.

[453] Valentine, G. A., Palladino, D. M., Agosta, E., Taddeucci, J., \& Trigila, R. (1998). Volcaniclastic aggradation in a semiarid environment, northwestern Vulcano Island, Italy. Geol Soc Am Bull, 110(5), 630-43.

[454] Bryan, S. E., Marti, J., \& Cas, R. A. F. (1998). Stratigraphy of the Bandas del Sur Formation; an extracaldera record of Quaternary phonolitic explosive eruptions from the Las Canadas edifice. Tenerife (Canary Islands) Geol Mag, 135(5), 605-36.

[455] Martí, J., Mitjavila, J., \& Araña, V. (1994). Stratigraphy, structure and geochronology of the Las Cañadas caldera (Tenerife, Canary Island). Geol Mag, 131(6), 715-27.

[456] Shakesby, R. A. (2011). Post-wildfire soil erosion in the Mediterranean: Review and future research directions. Earth-Science Reviews, 105(3-4), 71-100.

[457] Inbar, M., Tamir, M., \& Wittenberg, L. (1998). Runoff and erosion processes after a forest fire in Mount Carmel, a Mediterranean area. Geomorphology, 24(1), 17-33.

[458] Trimble, S. W., \& Mendel, A. C. (1995). The cow as a geomorphic agent- A critical review. Geomorphology, 13(1-4), 233-53.

[459] Butler, D. R. (1995). Zoogeomorphology- Animals as Geomorphic Agents. Cambridge, UK: Cambridge University Press.

[460] Boelhouwers, J., \& Scheepers, T. (2004). The role of antelope trampling on scarp erosion in a hyper-arid environment, Skeleton Coast, Namibia. J Arid Environ, 58(4), 545-57.

[461] Butler, D. R. (1993). The Impact of Mountain Goat Migration on Unconsolidated Slopes in Glacier National Park, Montana. The Geographical Bulletin, 35(2), 98-106.

[462] Zolitschka, B., Schäbitz, F., Lücke, A., Corbella, H., Ercolano, B., Fey, M., et al. (2006). Crater lakes of the Pali Aike Volcanic Field as key sites for paleoclimatic and paleoecological reconstructions in southern Patagonia, Argentina. J S Am Earth Sci, 21(3), 294-309.

[463] Hably, L., \& Kvaček, Z. (1998). Pliocene mesophytic forests surrounding crater lakes in western Hungary. Review of Palaeobotany and Palynology, 101(1), 257-69.

[464] Inbar, M., Hubp, J. L., \& Ruiz, L. V. (1994). The geomorphological evolution of the Paricutin cone and lava flows, Mexico, 1943-1990. Geomorphology, 9, 57-76.

[465] Sucipta, I. G. B. E., Takashima, I., \& Muraoka, H. (2006). Morphometric age and petrological characteristic of volcanic rocks from the Bajawa cinder cone complex, Flores, Indonesia. J Mineral Petrol Sci, 101(2), 48-68.

[466] Németh, K., Suwesi, S. K., Peregi, Z., Gula'csi, Z., \& Ujszászi, J. (2003). Plio/Pleistocene Flood Basalt Related Scoria and Spatter Cones, Rootless Lava Flows, and Pit Craters, Al Haruj Al Abiyad, Libya. Geolines, 15, 98-103. 
[467] Moufti, M. R., Moghazi, A. M., \& Ali, K. A. (2012). Geochemistry and Sr-Nd-Pb isotopic composition of the Harrat Al-Madinah Volcanic Field, Saudi Arabia. Gondwana Res, 21(2-3), 670-89.

[468] Cabrera, A. P., \& Caffe, P. J. (2009). The Cerro Morado Andesites: Volcanic history and eruptive styles of a mafic volcanic field from northern Puna, Argentina. J S Am Earth Sci, 28(2), 113-31.

[469] Manville, V., Németh, K., \& Kano, K. (2009). Source to sink: A review of three decades of progress in the understanding of volcaniclastic processes, deposits, and hazards. Sediment Geol, 220(3-4), 136-61. 
